\title{
ESTABILIDADE FENOTÍPICA DE PORTA-ENXERTOS PARA LARANJA 'NATAL' Q Qitrus sinensis (L.) OSBECK NAS CONDIÇÕES ECOLÓGICAS DO RECÔNCAVO BAIANO
}

WALTER DOS SANTOS SOARES FILHO

Orientador: JOSÉ BRANCO DE MIRANDA FILHO

Dissertação apresentada à Escola Superior de Agricultura "Luiz de Queiroz", da Universidade de São Paulo, para obtenção do título de Mestre em Agronomia. Área de Concentração: Genética $\theta \mathrm{M} \theta$ Ihoramento de Plantas.

\footnotetext{
$P|R A C| C A B A$

Estado de São Paulo - Brasil Janeiro - 1984
} 


\section{Aos meus pais, \\ pelo carinho e orientação de sempre, OFEREÇO}

à minha esposa, pelo companheirismo de todas as horas, 


\section{AGRADECIMENTOS}

- Ao Prof. José Branco de Miranda Filho, pela orientação segura;

- ao Prof. Natal Antônio Vello, pela sugestão deste estudo;

- ao amigo e companheiro Almir Pinto da Cunha Sobrinho, pelo apoio e colaboracão;

- ao Centro Nacional de Pesquisa de Mandioca e Fruticultura, da EMBRAPA, pela oportunidade de realizaça do curso e pela cessão dos dados;

- aos professores do Curso de Genética e Melhoramento de plantas, pelos ensinamentos ministrados;

- ao colega Antonio Carlos de oliveira, pelo auxilio na ärea de estatistica;

- à prima Dirce Pestana Soares, pelas correcões relativas ao português do texto;

- aos professores Lázaro José Chaves e Isaías olivio Geraldi, pelas colaboraçöes;

- à Srạ Sônia Novaes Rasera, pelos servicos datilogrä́ficos;

- aos demais que, embora não mencionados, con tribuiram para a realizaço deste trabalho; 
pägina

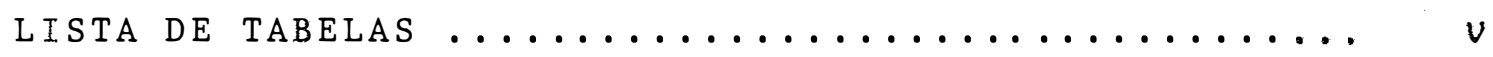

LISTA DE FIGURAS .............................

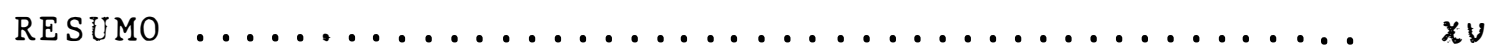

SUMMARY $\ldots \ldots \ldots \ldots \ldots \ldots \ldots \ldots \ldots \ldots$

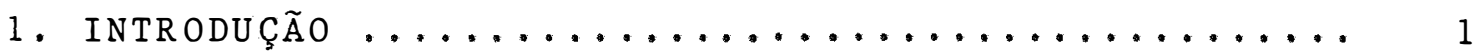

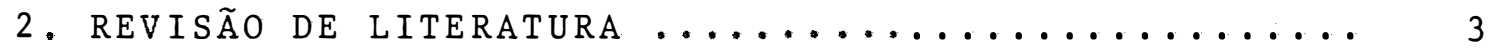

2.1. 0 papel do porta-enxerto na citricultura.... 3

2.1.1. Influência do porta-enxerto sobre a

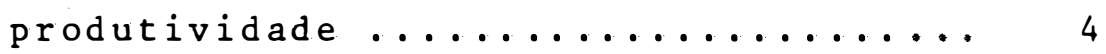

2.1.2. Influência do porta-enxerto sobre o

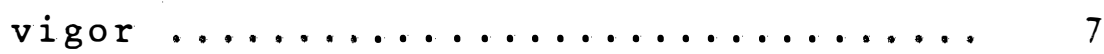

2.1.3. Influência do porta-enxerto sobre a

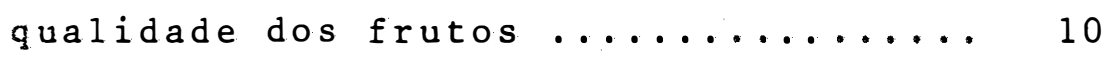

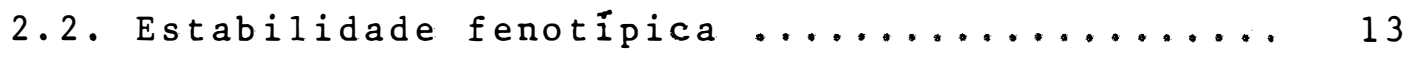

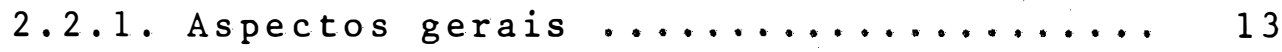

2.2.2. Métodos utilizados na avaliação da estabilidade fenotípica ............. 17

2.2.3. Estabilidade fenotípica e produção

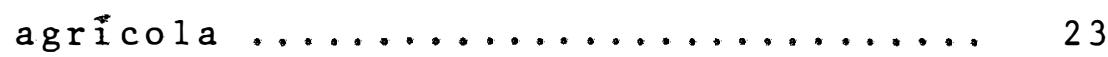

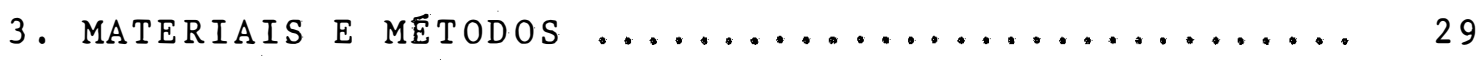

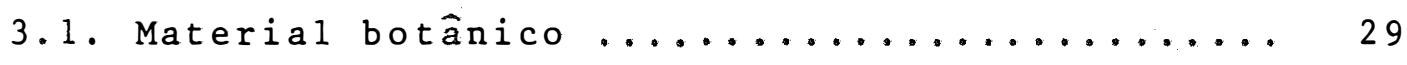

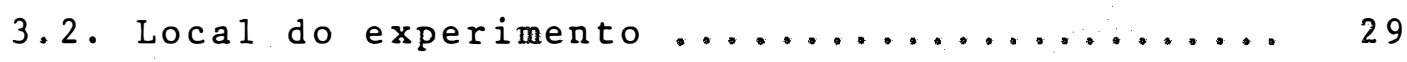

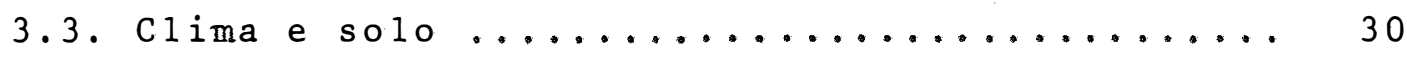

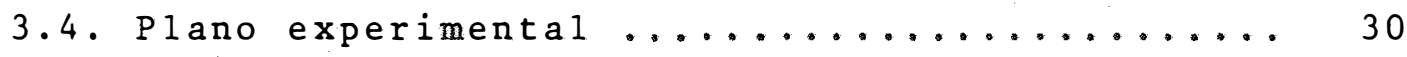

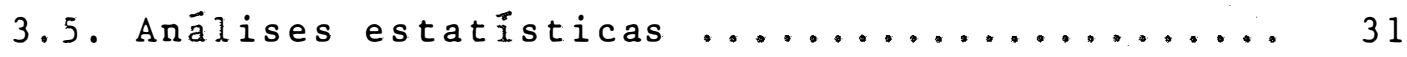

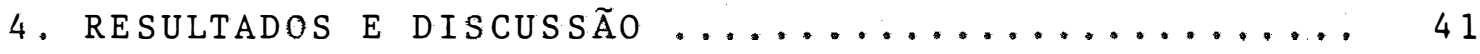

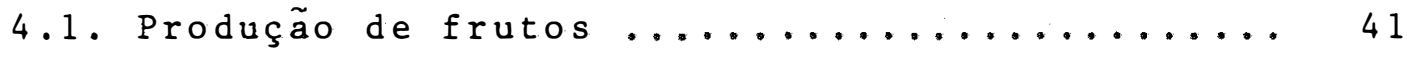

4.2. Vigor das combinações copa/porta-enxerto ....5 2

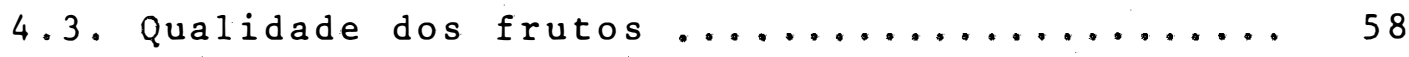

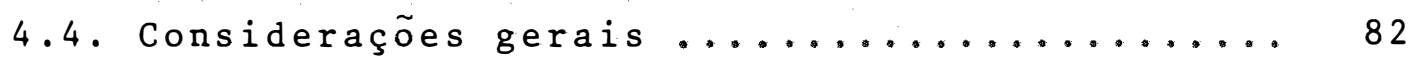

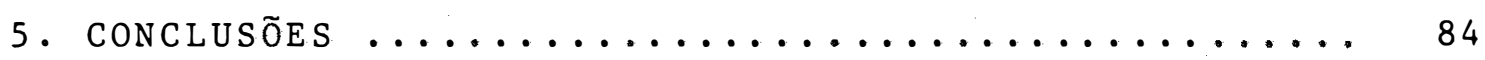

6 . Literatura CITAdA $\ldots \ldots \ldots \ldots \ldots . \ldots \ldots$

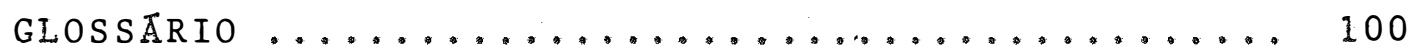

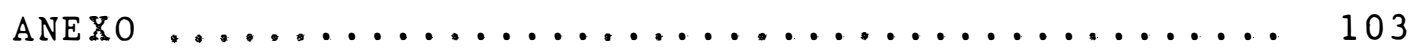

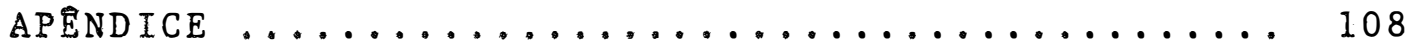




\section{LISTA DE TABELAS}

Tabela no

pāgina

1 Anảlise da variância em blocos casualizados com parcelas subdivididas no tempo, considerando $\underline{N}$ porta-enxertos para copa de laranja' 'Natal', ensaiados em J repe-

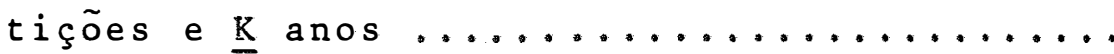

2 Anảlise da variância fornecendo as respos tas linear e não linear de $N$ porta-enxertos, estudados em $\mathrm{J}$ repetições e $\underline{K}$ anos (adaptação do modelo de EBERHART e RUSSEL,

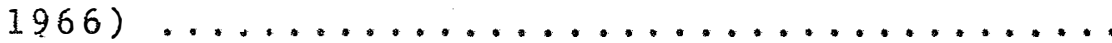

3 Esperanças das somas de quadrados e dos quadrados médios de anos dentro de portaenxertos e do residuo combinado, entre outras fontes de variação, relacionadas à anālise da estabilidade fenotípica (Tabe-

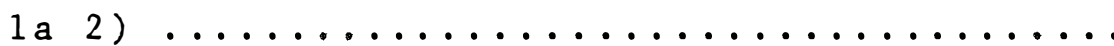

4 Anälise da variância em blocos casualizados com parcelas subdivididas no tempo, relativa à produção média de frutos, em $\mathrm{kg} / \mathrm{planta,}$ considerando cinco porta-enxer tos para copa de laranja 'Natal', ensaiados em cinco repetições e onze anos no Re

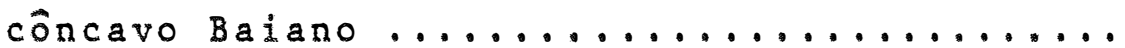


5 Anālise da variância da produção média de frutos, em $\mathrm{kg}$ por planta, considerando cinco porta-enxertos para copa de laranja 'Natal', ensaiados em onze anos no Recôncavo Baiano (adaptação do modelo de

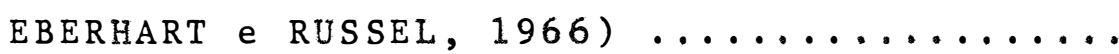

6 Produções mëdias de frutos, coeficientes de regressão (b), variâncias dos desvios da regressão $\left(\hat{\sigma}_{d}^{2}\right)$ e coeficientes de deter minação $\left(R^{2}\right)$, considerando cinco porta-en xertos para copa de laranja 'Natal', ensaiados em onze anos no Recôncavo Baiano...

7 Anālise da variância em blocos casualizados com parcelas subdivididas no tempo, relativa a dados médios de circunferência da copa (m), altura da planta (m) e diâmetro do tronco ( $\mathrm{cm}$ ), considerando cinco porta-enxertos para copa de laranja 'Natal', ensaiados em cinco repetições e cin-

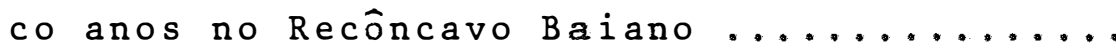

8 Anālise da variância de dados médios de circunferência da copa (m), altura da planta (m) e diâmetro do tronco ( $\mathrm{cm}$ ), con siderando cinco porta-enxertos para copa de laranja' 'Natal', ensaiados em cinco anos no Recôncavo Baiano (adaptação do mo delo de EBERHART e RUSSEL, 1966) .......... 
9 Valores médios ( $\bar{X})$ de circunferência da copa, altura da planta e diâmetro do tron co, com os respectivos coeficientes de re gressão (b), variâncias dos desvios da re gressão $\left(\hat{\sigma}_{\mathrm{d}}^{2}\right)$ e coeficientes de determinação $\left(R^{2}\right)$, considerando cinco porta-enxertos para copa de laranja 'Natal', ensaiados em cinco anos no Recôncavo Baiano ......

10 Anālise da variância em blocos casualizados com parcelas subdivididas no tempo, relativa a dados médios de peso ( $g$ ), altura (cm), diâmetro ( $\mathrm{cm})$, espessura da casca (mm), suco (\%), acidez total (\%), sọ 1 idos solūveis ( ${ }^{\circ}$ brix) e relação acidez/ sólidos solūveis dos frutos, considerando cinco porta-enxertos para copa de laranja 'Natal', ensaiados em cinco repetições e cínco anos no Recôncavo Baiano ............

11 Anälise da variância de dados médios de peso ( $\mathrm{g})$, altura ( $\mathrm{cm}$ ), diâmetro ( $\mathrm{cm})$, espessura da casca (mm), suco (\%), acidez total (\%), sólidos solūveis ( ${ }^{0}$ brix) e re 1 ação acidez/sólidos solúveis dos frutos, considerando cinco porta-enxertos para co pa de laranja 'Natal', ensaiados em cinco anos no Recôncavo Baiano (adaptação do mo delo de EBERHART e RUSSEL, 1966) ........... 
Valores médios ( $\bar{x})$ de peso, altura, diâmetro, espessura da casca, suco, acidez total, sỏlidos solüveis e relação acidez/ sólidos solúveis dos frutos, com os respectivos coeficientes de regressão (b), variâncias dos desvios da regressão $\left(\hat{\sigma}_{\mathrm{d}}^{2}\right)$ e coeficientes de determinação $\left(R^{2}\right)$, considerando cinco porta-enxertos para copa de laranja 'Natal', ensaiados em cinco

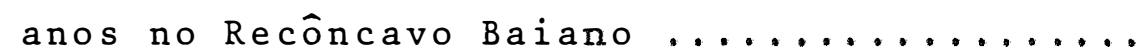

A. 1. Produções médias de frutos (kg/planta), in dices anuais $\left(I_{k}\right)$ e estimativas de $\alpha_{i}$ e $\left(1+8_{k}\right)$, relativos a ensaio conduzido no Recôncavo Baiano, considerando cinco porta-enxertos para copa de laranja 'Natal'

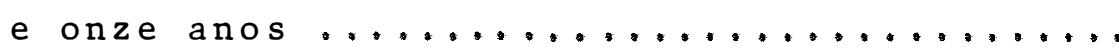

A.2. Valores médios de circunferência da copa, altura da planta e diâmetro do tronco,com os respectivos indices anuais $\left(I_{k}\right)$, relativos a ensaio conduzido no Recôncavo Baia no, considerando cinco porta-enxertos para copa de laranja 'Natal' e cinco anos....

A.3. Valores médios de peso, altura, diâmetro, espessura da casca, suco, acidez total, sólidos solūveis e relação acidez/sólidos solüveis dos frutos, com os respectivos indices anuais $\left(I_{k}\right)$, relativos a ensaio conduzido no Recôncavo Baiano, consideran do cinco porta-enxertos para copa de 1 a-

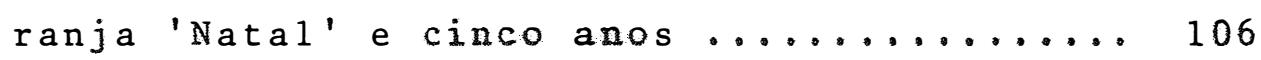


I Regressão linear da produção média de fru tos, considerando cinco porta-enxertos pa ra copa de laranja 'Natal', ensaiados em onze anos no Recôncavo Baiano ............

2 Relação entre produção média de frutos e coeficientes de regressão linear, considerando cinco porta-enxertos para copa de laranja 'Natal', ensaiados em onze anos

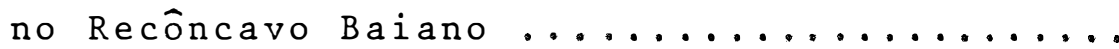

3 Regressão linear da circunferência média da copa, considerando cinco porta-enxertos para copa de laranja 'Natal', ensaiados em cinco anos no Recôncavo Baiano ............

4 Relação entre circunferência média da copa e coeficientes de regressão linear,con siderando cinco porta-enxertos para copa de laranja' 'Natal', ensaiados em cinco

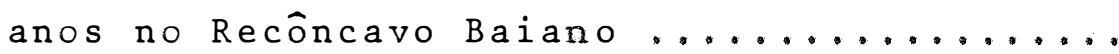

5 Regressão linear da altura mëdia da planta, considerando cinco porta-enxertos para copa de laranja 'Natal', ensaiados em

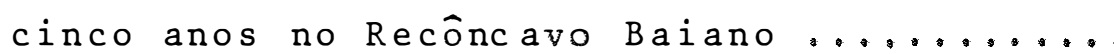

6 Relação entre altura média da planta e coeficientes de regressão linear, conside rando cinco porta-enxertos para copa de laranja' 'Natal', ensaiados em cinco anos

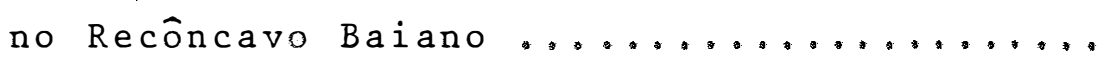


7 Regressão linear do diâmetro médio do tron co, considerando cinco porta-enxertos para copa de laranja' 'Natal', ensaiados em cinco anos no Recôncavo Baiano ............

8 Relação entre diâmetro médio do tronco e coeficientes de regressão 1 inear, conside rando cinco porta-enxertos para copa de laranja 'Natal', ensaiados em cinco anos

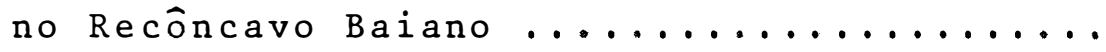

9 Regressão 1 inear do peso médio dos frutos, considerando cinco porta-enxertos para co pa de laranja 'Natal', ensaiados em cinco

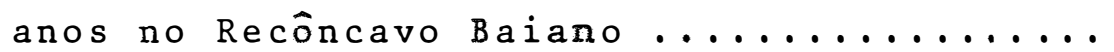

10 Relação entre peso médio dos frutos e coeficientes de regressão linear, conside rando cinco porta-enxertos para copa de laranja 'Natal', ensaiados em cinco anos

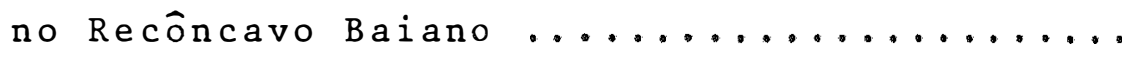

11 Regressão linear da altura média dos frutos, considerando cinco porta-enxertos pa ra copa de laranja 'Natal', ensaiados em

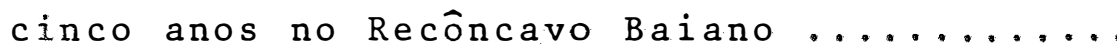

12 Relação entre altura média dos frutos e coeficientes de regressão 1 inear, conside rando cinco porta-enxertos para copa de laranja 'Nata1', ensaiados em cinco anos

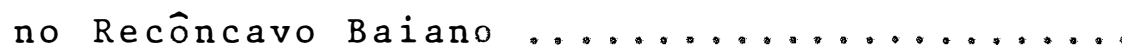


13 Regressão linear do diâmetro médio dos frutos, considerando cinco porta-enxertos para copa de laranja 'Natal', ensaiados em cinco anos no Recôncavo Baiano ..........776

14 Relação entre diâmetro médio dos frutos e coeficientes de regressão linear, conside rando cinco porta-enxertos para copa de laranja 'Natal', ensaiados em cinco anos

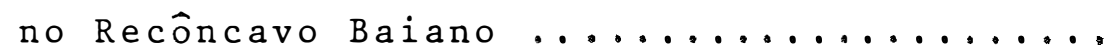

15 Regressão linear da espessura média da cas ca dos frutos, considerando cinco portaenxertos para copa de laranja 'Natal', eㅍ saiados em cinco anos no Recôncavo Baiano...

16 Relação entre espessura média da casca dos frutos e coeficientes de regressão linear, considerando cinco porta-enxertos para co pa de laranja 'Natal', ensaiados em cinco anos no Recôncavo Baiano ............. 77

17 Regressão 1 inear da porcentagem média de suco dos frutos, considerando cinco porta-enxertos para copa de 1 aranja 'Natal', ensaiados em cinco anos no Recôncavo Baia

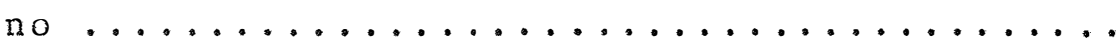

18 Relação entre porcentagem média de suco dos frutos e coeficientes de regressão 1 i near, considerando cinco porta-enxertos pa ra copa de laranja 'Natal', ensaiados em

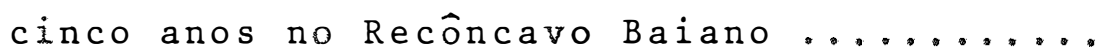


.xiii.

Figura no

página

19 Regressão linear da porcentagem média de acidez total dos frutos, considerando cin co porta-enxertos para copa de laranja 'Natal', ensaiados em cinco anos no Re-

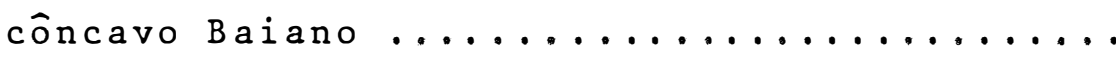

20 Relação entre porcentagem média de acidez total dos frutos e coeficientes de regres são linear, considerando cinco porta-enxertos para copa de laranja 'Natal', ensaiados em cinco anos no Recôncavo Baiano..

21 Regressão linear do teor médio de sólidos solúveis dos frutos, considerando cinco porta-enxertos para copa de laranja 'Natal', ensaiados em cinco anos no Recônca-

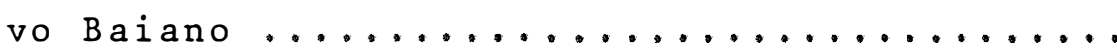

22 Relação entre teor médio de sôlidos soluveis dos frutos e coeficientes de regressão linear, considerando cinco porta-enxertos para copa de laranja 'Natal', ensaiados em cinco anos no Recôncavo Baiano..

23 Regressão linear da relação acidez/sólidos solúveis dos frutos, considerando cinco porta-enxertos para copa de laranja 'Natal', ensaiados em cinco anos no Recônca-

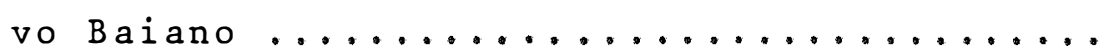


.xiv.

Figura no

página

24 Relação entre relação acidez/sólidos so-

1 üveis dos frutos e coeficientes de regressão linear, considerando cinco porta-enxertos para copa de laranja 'Natal', ensaiados em cinco anos no Recôncavo Baia

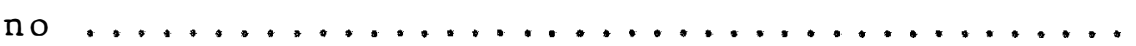




\title{
ESTABILIDADE FENOTIPICA DE PORTA-ENXERTOS PARA \\ LARANJA 'NATAL' Citrus sinensis ( $L$. ) Osbeck NAS \\ CONDIÇÕES ECOLOGICAS DO RECONNCAVO BAIANO
}

\author{
Autor: Walter dos Santos Soares Filho \\ Orientador: Prof. Dr. José Branco de Miranda Fo
}

RESUMO

Combinações de 1 aranja 'Natal' com cinco porta-enxertos, a saber, 1 imões 'Cravo', 'Rugoso FM' e 'Rugoso da Flórida', laranja 'Caipira' e tangerina 'Dancy', foram submetidas a um estudo da estabilidade fenotípica relativo à produção de frutos, vigor da copa e qualidade dos frutos, utilizando-se, para tanto, de metodologia proposta por EBERHART e RUSSEL (1966). Os dados de produção de frutos, a lëm disso, foram analisados através de um modelo não-linear, sugerido por VENCOVSKY e GERALDI (1977). O experimento foi instalado no Centro Nacional de Pesquisa de Mandioca e Fruti cultura - CNPMF, da Empresa Brasileira de Pesquisa Agropecua a ria - EMBRAPA, localizado no município de Cruz das Almas, Re cóncavo Baiano, O delineamento experimental utilizado foi o de blocos casualizados com parcelas subdivididas no tempo, tendo-se em vista que as observações se deram nas mesmas par celas ao longo de anos sucessivos. O estudo compreendeu a maior parte do periodo de vida ütil do pomar experimental, cu ja duração, sob condições tropicais, está em torno de 20 anos.

A produção de frutos, assim como as caracteristicas de vigor da copa e qualidade dos frutos, apresentaram relações predominantemente lineares frente às variaçós ecológicas anuais. Muito embora a interação porta-enxertos 
$x$ anos tenha sido explicada por efeitos de caräter principal mente aditivos, efeitos multiplicativos tambëm se fizeram presentes na ação das variações anuais sobre o comportamento da produção das combinações citricas avaliadas.

Os 1 imões 'Rugoso da Flórida' e 'Rugoso FM' destacaram-se pelo elevado vigor e produtividade que induziram às copas, relacionando-se a coeficientes de regressão li near numericamente superiores a 1,0, relativamente às citadas variāveis. Manifestaram respostas previsíveis no que tange à maioria dos caracteres analisados, constituindo exceções o teor de sólidos solúveis e a porcentagem de suco dos frutos, respectivamente para o primeiro e segundo portaenxertos mencionados. Com base em um exame global das características estudadas, pode-se concluir que esses "cavalos", no conjunto considerado, foram os que apresentaram me1 hor comportamento em combinação com a laranja 'Natal'.

0 imão 'Cravo', porta-enxerto atualmente mais empregado na citricultura brasileira, mostrou-se inadequado ao suporte de copas da referida laranja doce, face à imprevi sibilidade do seu comportamento no tocante à produção de fru tos, circunferência da copa e relação acidez/sólidos solúveis dos frutos, a par de niveis de produtividade inferiores aos constatados para os 1 imões rugosos anteriormente citados, considerando-se as condições do ensaio. Situação seme1 hante foi verificada para a laranja 'Caipira', exceção feita à previsibilidade de suas respostas concernentes à relação acidez/sólidos solúveis dos frutos. A tangerina 'Dancy', apesar de ter apresentado comportamento previsivel para a to talidade das caracteristicas avaliadas, determinou as mais baixas produçóes de frutos, sendo, portanto, contra-indicada como porta-enxerto para a laranja 'Natal'. 
PHENOTYPIC STABILITY OF ROOTSTOCKS FOR 'NATAL' SWEET ORANGE

Citrus sinensis ( $L$. ) Osbeck AT THE ECOLOGICAL

CONDITIONS OF "RECÔNCAVO BAIANO"

Author: Walter dos Santos Soares Filho

Adviser: Prof.Dr. Josē Branco de Miranda Fo

SUMMARY

A research was carried out with 'Natal' sweet orange on five different rootstocks, that are, 'Rangpur' lemon, 'FM Rough' lemon, 'Florida Rough' lemon, 'Caipira' sweet orange, and 'Dancy' mandarin. The study focused the phenotypic stability of these citrus cultivars with regard to the productivity, vigor, and fruit quality, based on EBERHART'S and RUSSEL'S (1966) methodology. The fruit production data also were analyzed by a non-1inear model as suggested by VENCOVSKY and GERALDI (1977) for the study of genotype-environment interaction. The experiment was carried out in the "Centro Nacional de Pesquisa de Mandioca e Fruticultura - CNPMF", of the "Empresa Brasileira de Pesquisa Agropecuāria - EMBRAPA", located in Cruz das Almas, "Recôncavo Baiano", Brazil (12 ${ }^{\circ} 40^{\prime} 39^{\prime}$ south latitude, 39 $6^{\prime} 23^{\prime \prime}$ west longitude, and 225 meters of a1titude). It was used a randomized block design with split-plot in time, considering that the observations were taken on the same plots during different years. The study comprised almost all of the orchard's 1 ife span, whose duration under tropical conditions is about 20 years.

The fruit production, besides the vigor's and fruit quality's characteristics, presented responses 
predominantly linear to year variations. In spite of the fact that the genotype-environment interaction was explained primarily by aditive effects, the multiplicative model also showed some fitness to the year variations upon the fruit production.

The 'Florida Rough' 1 emon and 'FM Rough' 1 emon induced the best vigor and productivity to the trees, as verified through linear regression coefficients greater than 1.0, concerning to these characteristics. They manifested yet predictable responses to most of the variables analyzed, exceptions due to soluble solids and juice fruit quantities, regard to the first and second rootstocks, respectively. In general terms, these rough lemons can be considered, in the group of genotypes investigated, the best rootstocks for 'Natal' sweet orange at the ecological conditions of "Recôncavo Baiano".

The 'Rangpur' lemon, principal rootstock in the brazilian citrus industry, presented inadequate behavior in combination with 'Natal' sweet orange, considering its unpredictable responses in respect of fruit production, tree circumference and acid/soluble solids ratio of fruits, as well as inferior productivity in relation to the rough lemons included in this study. Similar behavior was verified to 'Caipira' sweet orange, except its predictable response regard to acid/soluble solids ratio of fruits. The 'Dancy' mandarin, by this time, in spite of its predictablë behavior with relation to all characteristics analyzed, was the rootstock that induced the lowest productivity to the citrus trees. 


\section{INTRODUCAAO}

O Brasil apresenta condições edafo-climáticas que viabilizam a citricultura em toda sua extensão territorial, conforme se verifica pelo estabelecimento de uma inigualável população de plantas citricas, superior a 150 milhões de ärvores, com produção global ao redor de 8 milhões de toneladas de frutos anuais e distribuição abrangendo uma ärea estimada em 600 mil hectares (SALIBE, 1978; MOREIRA, 1980), conferindo-1he a expressiva posição de segundo maior produtor mundial de citros, logo após os Estados Unidos, e de primeiro produtor e exportador de suco concentrado de 1 aranja. Esse acentuado crescimento teve como estimulo princi pal o processamento industrial da fruta, especialmente no Es tado de São Paulo, que detém cerca de $80 \%$ da produção nacional e industrializa aproximadamente $75 \%$ de sua safra (AMARO, 1982).

Por se tratar de uma cultura perene, sujeita, portanto, aos efeitos determinados por variações ambientais ao longo de diversos anos de cultivo, a identificação de com binações copa/porta-enxerto superiores e de comportamento es tävel constitui objetivo de grande interesse. Com base no exposto, o presente trabalho teve por finalidade avaliar a 
estabilidade fenotípica de copas de laranja 'Natal' em combi nação com diferentes porta-enxertos, no que diz respeito às caracteristicas de produção, vigor e qualidade dos frutos, utilizando-se, para tanto, de metodologia proposta por EBERHART e RUSSEL (1966). Espera-se, com isso, oferecer informacões que possam servir de subsidio à identificação de materiais elite em citros, assim como em outras culturas semelhantes, particularmente naquelas perenes e de propagaça vegetativa. 


\section{REVISATO DE LITERATURA}

\subsection{O papel do porta-enxerto na citricultura}

A propagação dos citros é normalmente feita através da enxertia, pois as plantas obtidas a partir de sementes resultam em ärvores que exigem de 6 a 8 anos para o desenvolvimento dos primeiros frutos, e alguns anos mais para a produção das primeiras safras comerciais (cunHA Sobrinho et alii, 1980). Afora a precocidade de producão, diversas outras caracteristicas apresentadas pela copa podem ser modificadas pelo "cavalo" ou porta-enxerto, a saber: produti vidade, vigor, qualidade e conservacão da fruta pós-colheita, transpiração, fertilidade do pólen, composição orgānica e inorgānica das folhas e frutas, capacidade de absorcão, sintese e utilização de nutrientes, tolerāncia à salinidade, resistēncia à seca, à geada, às pragas e às doenças. Tais ca racterísticas são determinadas por interacões específicas en tre a copa e o porta-enxerto, manifestando-se através de alterações morfológicas e fisiológicas (SALIBE, 1978). Em vis ta disso, torna-se fácil depreender que o porta-enxerto ocupa posição de grande relevo na citricultura, o que motivou a realização de inúmeros estudos relativos aos efeitos resul tantes de interações entre copas e porta-enxertos. Dentre 
essas pesquisas procuraremos abordar, contudo, somente aquelas relacionadas à produtividade, vigor e qualidade dos frutos, que constituem aspectos de maior interesse no presente trabalho. Para esclarecimentos sobre a nomenclatura cientifica, bem como sobre o significado da terminologia empregada na designação de tipos híbridos, relativos aos materiais cítricos apresentados no texto, consultar glossário (pág.101).

\subsubsection{Influência do porta-enxerto sobre a produtivi dade}

A influēncia do porta-enxerto sobre a produti vidade da copa citrica é um fato inconteste, haja visto que a produção económica dos citros depende grandemente da escolha de combinações adequadas. FIGUEIREDo et ali $i$ (1981), es tudando dez porta-enxertos para copa de laranja 'Barão', verificaram que as plantas enxertadas sobre tangelo 'Orlando' e tangerina 'Sunki' apresentaram maior número de frutos que aquelas enxertadas sobre 1 imão 'Rugoso Nacional' e Poncirus trifoliata (L.) Raf., manifestando as combinaçoes com este ültimo, porém, as maiores produçóes por unidade de volume de copa. DORnElles (1981) citou que, dentre vinte e cinco combinações para a 'Mexerica do Rio', maiores produtividades fo ram induzidas, em ordem decrescente, pelos limoeiros 'Cravo', seleção Taquaritinga, 'Rugoso da Flörida' e 'Volkameria no', enquanto que o citrandarin 310 e o citrange $\mathrm{C}-14^{2}$ determinaram baixa produtividade às plantas. Copas de limão 'Feminello', seleção Santa Teresa, apresentaram produções ligei ramente superiores em combinações com 1 imão 'Cravo', em rela ção àquelas nas quais as copas estavam enxertadas sobre sele ções de limão 'Volkameriano' (SALIBE e MISCHAN, 1981). HEARN et alii (1974) comentaram tambëm que combinaçóes cítricas en volvendo os 1 imóes 'Rugoso da Fiórida' e 'Cravo' produziram elevado número de frutos, verificando-se o conträrio quando 
os porta-enxertos utilizados foram a laranja 'Azeda' e a tan gerina 'Cleópatra'. Parte dessas observaçóes concordou com dados obtidos por CoOK et a $i i$ (1952), que destacaram a elevada produtividade determinada pelo 1 imão 'Rugoso da F1órida' às copas das laranjas doces 'Parson Brown' e 'Valência', em comparação com outros seis porta-enxertos. Resultados se melhantes foram encontrados por CUNHA Sobrinho et a $i$ i (1978), estudando combinações de laranja 'Baianinha' com oito porta-enxertos, e por SOARES Filho et ali $i$ (1980), em tra balho experimental onde foi avaliado o comportamento de cinco porta-enxertos para copa de laranja 'Natal', constatando-se que os limões 'Rugoso da Flörida' e 'Rugoso FM', sendo este último uma seleção do primeiro, induziram destacada pro dução às copas. MOREIRA et alii (1960) mencionaram, por outro 1 ado, que copas de 1 imão 'Eureka', das 1 aranjas doces 'Baianinha', 'Pera' e 'Hamlin', e de 'Mexerica', apresentaram baixas produções quando enxertadas sobre o limão 'Rugoso da Flórida'. WUTSCHER e SHULL (1976) não concordaram com as ob servações efetuadas por HEARN et alii (1974), no que se refe re às baixas produtividades influenciadas às copas cítricas pela tangerina 'Cleópatra' e pela laranja 'Azeda', dadoque, dentre onze porta-enxertos avaliados para copa de laranja 'Marrs', combinações envolvendo os referidos porta-enxertos foram superadas em produção somente por aquelas em que o "ca valo" era o citrumelo 'Swingle'. CunHA Sobrinho et ali (1980) citaram, igualmente, que a tangerina 'Cleópatra', seguida pelo limão 'Cravo', foi o porta-enxerto que imprimiu maior produtividade à copa de laranja 'Pera', conforme resul tados provenientes de médias de um período de oito safras, em comparação com outros cinco porta-enxertos.

SALIBE (1978) salientou que, de um modo geral, tèm se sobressaido como mais produtivas aquelas combina ções de que participam como porta-enxertos o limão 'Cravo', tangerinas 'Sunki' e 'Kinnow' (hibrido entre as tangerinas 
'King' e 'Willow leaf'), citrumelo 'Swingle', citrange 'Morton' e algumas laranjas doces. POMPEU Jr. et a $i$ i (1978), por sua vez, indicaram que, além do limão 'Cravo', as tangerinas 'Oneco' e 'Batangas', o tangelo 'Orlando' e a laranja 'Hamlin', induzem boa produtividade às copas.

$$
\text { Convém esclarecer, todavia, que nem sempre }
$$
plantas mais vigorosas, e portanto de maior porte, relacionam-se a uma maior produtividade por unidade de volume de co pa, muito embora possam apresentar um número total de frutos superior ao observado em plantas menos desenvolvidas, confor me verificado por TEÓFILO Sobrinho et ali $i$ (1973). Esses au tores constataram que copas de laranja 'Valéncia', enxertadas sobre nove porta-enxertos, apresentaram as mais expressi vas produções, por unidade de volume, quando em combinação com o citrange 'Troyer', 1 imões 'Rugoso da Flörida' e 'Rugoso Nacional' e Poncirus trifoliata, porta-enxertos estes que induziram a formação de copas menos vigorosas. Essas observações foram confirmadas por POMPEU Jr. et alii (1978), os quais verificaram que, dentre dezoito porta-enxertos estudados para copa de laranja 'Hamlin', o citrange 'Rusk' foi o que determinou maior produtividade por volume de copa, apesar de ter acarretado um menor desenvolvimento e, como conse qüência, baixa produção por planta. POMPEU Jr. et ali (1981) comentaram, igualmente, que o Poncirus trifoliata, se leção Limeira, de um total de dezoito porta-enxertos avaliados em combinação com laranja 'Valência', apesar de ter influenciado uma menor produção de frutos por planta, relacionou-se a uma maior produtividade, segundo o número de frutos produzidos por metro cübico de copa. Situação semelhante foi observada em combinações de laranja 'Barão' com Poncirus trifoliata (FIGUEIREDO et alii, 1981), conforme já mencionado. 


\subsubsection{Influência do porta-enxerto sobre o vigor}

Verifica-se, em plantas, uma íntima associação entre crescimento das raízes e das partes aéreas (MAGALHÃEs e SILVA, 1978). CASTLE e KREZDORN (1974), analisando onze porta-enxertos em combinação com tangelo 'orlando', cons tataram uma correlação positiva significativa entre altura média da copa e profundidade do sistema radicular. Combinações com limão 'Rugoso da Flörida' apresentaram maiores altu ras de planta e profundidade do sistema radicular, observando-se o contrário naquelas que tinham como porta-enxerto o trifoliata 'Rubidoux'. Quanto ao peso médio das raízes de alimentação, entretanto, os referidos autores constataram que esse paràmetro não foi proporcional ao tamanho da copa e à profundidade do sistema radicular, uma vez que valores máximos foram obtidos em combinações com 1 imão 'Rugoso da Flórida' e com trifoliata 'English Small', as quais se apresentaram muito e pouco vigorosas, respectivamente.

PARENTE et arii (1981), estudando o comportamento de quatorze porta-enxertos sob copa de tangerina'Poncã', concluiram que os "seedlings" mais vigorosos nem sempre correspondem àqueles que, quando enxertados, induzem maior desenvolvimento às copas, uma vez que os 1 imões 'Rugoso da Africa' e 'Rugoso da Flörida', que apresentaram maior precocidade até a enxertia, por ocasião do transplante das mudas ocuparam posições intermediảrias, no tocante ao vigor das combinações de que participaram.

$$
\text { COOK et alii (1952) verificaram que, dentre }
$$

sete porta-enxertos avaliados para copas das laranjas 'Parson Brown' e 'Valēncia', o limão 'Rugoso da Flörida' foi aquele que influenciou o desenvolvimento de combinações mais vigorosas, observando-se que a taxa de crescimento determina da por esse "cavalo" mostrou-se relativamente alta durante 
os primeiros anos, sendo superada, apös esse periodo, por ou tros porta-enxertos de crescimento mais lento. Situaça semelhante foi obtida em combinações de limão 'Rugoso Nacional' com copas de limão 'Eureka', de laranjas 'Baianinha', 'Pera', 'Hamlin' e 'Maracanã' e de 'Mexerica', as quais destacaram-se como mais vigorosas durante a fase inicial de desenvolvimento, ocorrendo o conträrio em combinações com a laranja 'Caipira', segundo resultados encontrados por MOREIRA et a $i$ i (1960) em pesquisa efetuada com diversos "cavalos". Esses mesmos autores mencionaram que o 1 imão 'Rugoso da Flórida', em contraste com outros trabalhos (COOK et alii, 1952 ; CASTLE e KREZDORN, 1974; SALIBE, 1978; CUNHA Sobrinho et a $i$ i, 1980), induziu baixo vigor às copas sobre ele enxertadas, o que concorda com dados obtidos por té́fllo sobrinho et alii (1973), relativos a combinaçóes de laranja 'valéncia' com nove porta-enxertos, tendo sido constatado que o 1 i mão 'Rugoso da Flörida', ao lado do citrange 'Troyer', limão 'Rugoso Nacional' e Poncirus trifoliata, determinou a formação de copas menos volumosas, verificando-se o conträrio em combinações incluindo as tangerinas 'Sunki' e 'Cleópatra' e - limão 'Cravo'. FIGUEIREDo et alii (1981), em trabalho ex perimental envolvendo dez porta-enxertos para laranja 'Barão', comentaram também sobre o desenvolvimento inferior observado em combinações com limão 'Rugoso Nacional' e Poncirus trifoliata, bem como sobre os maiores volumes de copa in fluenciados pelas tangerinas 'Sunki' e 'Cleópatra', cujas combinações foram superadas em vigor somente por aquelas nas quais o porta-enxerto era o tangelo 'orlando'. Este porta-enxerto, juntamente com as laranjas 'Hamlin' e 'Caipira', e com as tangerinas 'Kinnow', 'Swatow' e 'Cleópatra', conferi ram elevado vigor à copa de laranja 'Valéncia', dando-se o oposto com relação aos porta-enxertos 'Lima da Pérsia', trifoliata 'Limeira' e tangelo 'Minneola', conforme resultados alcançados por POMPEU Jr. et a $i i$ (1981). Copas de laranja 'Hamlin' enxertadas sobre a pröpria laranja 'Hamlin', tange- 
lo 'Orlando' e tangerina 'Gleópatra', confirmaram o maior vi gor conferido por esses porta-enxertos às combinações de que participam, dado que apresentaram, ao lado de combinaçós com as tangerinas 'Oneco' e 'Batangas' e com a laranja 'Flori da Sweet' os maiores volumes de planta, em comparação com aquelas enxertadas sobre outros doze porta-enxertos, entre os quais incluia-se o citrange 'Rusk', que determinou vigor menos acentuado às copas, segundo POMPEU Jr. et alii (1978).

CUNHA Sobrinho et alii (1980) destacaram o vi gor mais elevado apresentado pela laranja 'Pera' quando enxertada sobre tangerina 'Cleópatra', e enfatizaram também o pronunciado vigor que foi influenciado pelos 1 imoeiros 'Rugo so da Flörida' e 'Rugoso FM' às copas das laranjas 'Baiani nha' e 'Natal', em comparação com outros porta-enxertos.

SALIBE (1978) comentou que dentre os portarenxertos que normalmente induzem bom desenvolvimento às copas pode-se incluir a laranja 'Caipira', os limões 'Cravo' e 'Ru goso', bem como as tangerinas 'Cleōpatra' e 'Sunki'.

Combinações superiores, contudo, não devem obrigatoriamente apresentar porte avantajado, conforme mencionado no item anterior, dado que aumentos em produtividade podem ser obtidos através de uma maior densidade de plantio. A utilização de porta-enxertos apropriados presta-se à essa finalidade, considerando-se que o tamanho de uma planta citrica é, de certa forma, determinado por um balanço fisiológico entre os cultivares copa e porta-enxerto que a componem, podendo a planta enxertada manifestar um desenvolvimento com pletamente diferente daquele apresentado pela copa e pelo porta-enxerto, quando analisados separadamente. Alguns gēne ros afins ao Citrus, como Citropsis, Eremocitrus, Clymenia e Microcitrus, têm permitido reduções sensiveis no porte da planta, as quais, em alguns casos, chegam à ordem de $75 \%$, em comparação com o vigor observado em pomares comerciais. 0 
mecanismo que causa o nanismo das plantas, porëm, permanece desconhecido, parecendo provável a existēncia de problemas de incompatibilidade entre a copa e o porta-enxerto interferindo nesse comportamento (CASTLE, 1979). Plantas citricas enxertadas sobre Poncirus, gēnero monotipico também considerado ananicante, nem sempre, todavia, expressam essa caracteristica (CASTLE, 1979), sendo provável que tal situação seja devida a uma maior vulnerabilidade a déficits hidricos apresentada pelo poncirus tríoliata, como decorrēncia de seu sistema radicular pouco profundo, haja visto que, em solos que possuem boa retenção de umidade, laranjas doces em comb nação com esse "cavalo" podem manifestar desenvolvimento nor mal (CASTLE e KREZDORN, 1974 ).

Avaliaçóes no sentido de se utilizar porta-en xertos tetraplöides, de ocorrēncia natural ou artificial, tèm sido realizadas visando reduzir o porte da planta (HEARN et alii, 1974 e CHAPOT, 1975). Nove é o número haplóide de cromossomos para todas as espécies de Citrus, assim como para gēneros afins, a exemplo do Poncirus e Fortunella, sendo a condição diplöide predominante, muito embora formas tetraplóides tenham sido reportadas para esses gēneros, havendo também indicações de individuos triplöides, pentaplöides, he xaplöides, bem como aneuplöides (CAMERON e FROST, 1968 e CHAPOT, 1975 ).

\subsubsection{Influéncia do porta-enxerto sobre a qualidade dos frutos}

Webber, citado por MONTENEGRO et ali $i$ (1961), esclareceu que os frutos de quaisquer variedades citricas, embora conservem suas particularidades, sofrem uma influēncia do porta-enxerto quanto à expressão quantitativa de certas caracteristicas, da mesma forma que são afetados pelo am 
biente. Os referidos autores, por sua vez, comentaram que tal influência é devida a uma interação entre a copa e o por ta-enxerto, não decorrendo de uma ação isolada deste ültimo. Quando se comparam as caracteristicas dos frutos de uma determinada variedade copa, em combinação com diferentes porta-enxertos, verifica-se que estes podem induzir variaçós no tamanho, forma, cor e espessura da casca dos frutos, conteúdo de suco, acidez e açúcares, teor de vitamina $C$ e de sais minerais, nümero de sementes, entre outros fatores (SALIBE, 1978). No que se refere ao número de sementes, ao que parece, as razões que determinam acréscimos em sua quan tidade podem ser explicadas por aumentos da fertilidade do grão de pólen, devido a ações fisiológicas provocadas pela interação entre copa e porta-enxerto (MONTENEGRo et ali 1959).

SALIBE e MISCHAN (1978), estudando caracterís ticas de frutos das laranjas doces 'Hamlin', 'Baianinha', 'Westin', 'Ruby' e 'Itaborai', em combinação com cinco porta -enxertos, verificaram que os frutos de melhor qualidade, is to é, de casca fina e com melhor coloração alaranjada, com menor nümero de sementes e mais ricos em suco, acidez e sóli dos solúveis (açúcares), foram produzidos em combinações com Poncirus trifoliata. Situação conträria foi observada nas combinações com 1 imão 'Rugoso da Flórida', que induziu a for mação de frutos de qualidade inferior, enquanto que a laranja 'Caipira', tangerina 'Sunki' e o limão 'Cravo', determina ram o desenvolvimento de frutos com caracteristicas intermediärias, MOREIRA et a $i$ i (1960), a partir de resultados obtidos de combinações entre copas de 1 imão 'Eureka', laranjas 'Baianinha', 'Pera', 'Hamlin' e 'Maracanã', e de 'Mexerica', com diversos porta-enxertos, mencionaram, igualmente, a influência exercida pelo limão 'Rugoso da Flórida' no sentido de ocasionar a produção de frutos de qualidade inferior, o mesmo sendo verificado para o 1 imão 'Rugoso Nacional'. Esses 
resultados são corroborados por observaçóes realizadas por COOK et alii (1952) em combinações envolvendo copas das laranjas 'Parson Brown' e 'Valência', por MONTENEGRo et alii (1961) e por HEARN et alii (1974), chamando, estes ültimos, a atenção para a excelente qualidade de frutos determinada pela laranja 'Azêda' e tangerina 'Cleópatra', muito embora tais porta-enxertos causem redução no tamanho dos frutos.

DORNELLES (1981) constatou que, dentre vinte e cinco porta-enxertos avaliados para copas de 'Mexerica do Rio', os maiores pesos médios de frutos foram influenciados pelo 1 imoeiro 'Rugoso da Flórida' e pelo citrange C-41, veri ficando-se o conträrio para o citrandarim 309, citrange $C-14^{2}$ e 1 imoeiro 'Rugoso da Äfrica'. Outros autores têm con firmado o fato de que o limão 'Rugoso da Flórida' induz a formação de frutos com maior peso, a exemplo do que foi observado por CUNHA Sobrinho et ali $(1978)$ e por SOARES Filho et alii (1980), em combinações envolvendo, respectivamente, copas das laranjas 'Baianinha' e 'Natal', nas quais a seleção FM, desse porta-enxerto, relacionou-se à formação de fru tos com maiores pesos médios.

WUTSCHER e SHULL (1976) não constataram varia ções expressivas quanto ao tamanho, cor do suco e da casca, bem como porcentagem de suco dos frutos provenientes de combinações de laranja 'Marrs' com onze porta-enxertos. Esses autores estabeleceram, porém, que o citrange 'Morton' ocasionou a produção de frutos com cascas mais espessas, enquanto que os porta-enxertos tangerina 'Cleópatra',"Chinese box-orange"e laranja Taiwanica (suposto hibrido da laranja 'Azeda') determinaram o conträrio. Este ültimo porta-enxerto influenciou o desenvolvimento de frutos com teores de aci dez e sólidos solüveis mais baixos, em contraste com o que se observou em combinações com o citrumelo 'Swingle' e com um hibrido de tangerina 'Cleópatra' com citrange 'Troyer', respectivamente. 
O papel do porta-enxerto na qualidade dos fru tos, afora os comentários já feitos, pode ser melhor avaliado através de exemplos como o do Poncirus trifoliata, o qual, devido à excelente qualidade de frutos que induz às copas so bre ele enxertadas, a par de outras caracteristicas de interesse, tornou-se amplamente utilizado em värios paises, prín cipalmente nos Estados Unidos, Japão, Austrália e Argentina. No Brasil seu emprego tem sido mais generalizado no Rio Gran de do Sul. Em äreas tropicais, contudo, segundo estudo realizado por PASSos et alii (1973), no Estado da Bahia, esse porta-enxerto tem apresentado restrições com relação à sua adaptação, muito embora alguns de seus hibridos, tais como os citranges 'Morton' e 'Rusk', mostrem comportamento mais favorável à essas condições ecológicas. Estudos preliminares, realizados com plantas na fase de "seedling" e de mudas enxertadas em condições de viveiro, sugerem que outros hibri dos, a exemplo daqueles entre tangerina 'Sunki' com os trifo liatas 'Swingle' e 'English', também possam ser utilizados como porta-enxertos em regiões tropicais (PASSos et alii, 1976).

\subsection{Estabilidade fenotipica}

\subsubsection{Aspectos gerais}

Em termos práticos, o nümero potencial de ambientes distintos aos quais determinada planta pode ser sub metida é infinito, mesmo em se tratando de uma ärea restrita, tornando extremamente remota a probabilidade de duas plantas se sujeitarem a ambientes idēnticos (COMSTOCK, 1955

e COMSTOCK e MOLL, 1963). A esse complexo ünico, atuante so bre uma planta ou organismo particular, atribuiu-se a terminologia de microambiente, enquanto que ambientes compreendidos em uma àrea mais abrangente, embora com caracteristicas 
pröprias, são coletivamente referidos como macroambiente. Desse modo, um macroambiente é, na realidade, um conjunto de microambientes, sendo aquele, e não estes ültimos, o alvo de interesse dos melhoristas de plantas, no que diz respeito à identificação de materiais superiores (COMSTOCK e MOLL, 1963). Quanto às variações no ambiente estas, segundo ALLARD e BRADSHAW (1964), podem ser divididas em duas catego rias: previsiveis e imprevisiveis. A primeira inclui todas as condições ambientais permanentes, a exemplo das caracteristicas gerais de clima e solo, variações sistemáticas na duração do dia, bem como os tratos culturais impostos pelo homem, tais como época e densidade de plantio, métodos de co 1 heita e outras práticas agronómicas preestabelecidas. Já as variações imprevisíveis compreendem as flutuações climäticas, tais como pluviosidade e temperatura, entre outros fato res.

A ocorrência generalizada de interaçóes entre genótipo e ambiente causa sérios transtornos no que concerne ao desenvolvimento de variedades melhoradas, sejam estas representadas por 1 inhas puras, hibridos, ou qualquer outro ma terial com o qual o melhorista possa estar trabalhando (EBERHART e RUSSEL, 1966), comprometendo o progresso alcança do com a seleção (COMSTOCK e MOLL, 1963). Visando contornar esse problema, duas estratégias de ação poden ser adotadas, quais sejam a estratificação de uma àrea heterogênea em ambientes mais uniformes, para os quais seriam desenvolvidas variedades especificas ou, como segunda alternativa, seleça o de genotipos estáveis e superiores, adaptados a amplas condi ções ambientais. O primeiro enfoque, contudo, não é muito efetivo, desde que a interação entre genótipos e locais dentro de uma dada sub-região ainda permanece grande e, o que é mais importante, a estratificação não reduz a interação genó tipos $x$ anos (EBERHART e RUSSEL, 1966 e TAI, 1971), a qual, vale ressaltar, tem se mostrado superior àquela relativa a 
genótipos $x$ locais, conforme enfatizado por alguns autores (RASMUSSON e LAMBERT, 1961 e ALLARD e BRADSHAW, 1964). Assim sendo, a obtenção de genótipos estáveis constitui objeti vo de grande interesse. A esse respeito ALLARD e BRADSHAW (1964) comentaram que hả duas maneiras gerais através das quais uma variedade ou população pode adquirir estabilidade, denominando-as por tamponamento individual e tamponamento po pulaciona1. NASPOLINI Filho (1975), referindo-se ao assunto, utilizou as terminologias homeostase individual e homeostase de população, respectivamente. 0 tamponamento individual diz respeito à propriedade de um ünico genótipo produzir um fenótipo aceitável sob diferentes condições ambientais, estando mais relacionado a populaçoes geneticamente homogèneas, a exemplo de uma linha pura ou de um hibrido simples. Quanto ao tamponamento populacional este decorre da diversidade genética apresentada por um número suficiente de genótí pos que, em conjunto, determinam uma adaptação a amplas variações ambientais. Esta situação foi denominada por LEvINS (1963) como polimorfismo estático, caracterizando-se, confor me mencionado, pela existência de uma diversidade permanente e estável dentro de populações, onde cada tipo é superior aos demais em um determinado habitat ou fase ambiental. o re ferido autor citou também que, em termos de membros individuais de uma população, a adaptação pode ser distinguida em homeostase fisiológica e flexibilidade desenvolvimental. A primeira inclui a tolerāncia do organismo a condições desfavoráveis e sua capacidade de apresentar rápidas modificacoos reversiveis em suas caracteristicas internas (fisiológicas), como resposta a flutuações ambientais transitórias. Já a flexibilidade desenvolvimental se refere a modificações irre versiveis de um caräter adaptativo. O conceito de homeostase fisiológica foi desenvolvido por Cannon no inicio dos anos 30 , ocasião em que trouxe importante contribuição ao campo da fisiologia (LERNER, 1954 e LEWONTIN, 1957). Cabe acrescentar que um genótipo melhor adaptado poderia ser defi 
.16.

nido como aquele com capacidade de contribuir com maior núme ro de descendentes para as geracões seguintes, podendo essa definição, por analogia, ser estendida a uma população (LEWONTIN, 1957).

Evidências tanto diretas como indiretas indicam que os heterozigotos têm uma maior capacidade de adaptacão que os homozigotos, significando que entre plantas superiores e animais a seleção natural apresenta uma tendéncia em favor de uma maior complexidade bioquimica ou enzimática, claramente vantajosa em um organismo sujeito a condições ambientais variàveis, por lhe conferir maiores propriedades de tamponamento (HALDANE, 1954 e LEWIS, 1954). Em plantas, mais especificamente, essa superioridade dos heterozigotos pode ser observada tanto em alögamas como em autógamas, conforme exemplos verificados em milho (ADAMS e SHANK, 1959 e ROWE e ANDREW, 1964), cevada (JAIN e ALLARD, 1960) e Phaseolus lunatus (ALLARD e WORKMAN, 1963). QUISENBERRY e KOHEL (1971), em trabalho conduzido com algodão, todavia, não cons tataram influências da heterozigosidade, bem como do nivel de ploidia, sobre a estabilidade fenotipica de oito caracteres distintos. Convém esclarecer que a heterozigosidade por si só não explica a homeostase, uma vez que hibridos de mi1 ho com o mesmo nivel de heterozigosidade freqüentemente manifestam propriedades de tamponamento significativamente diferentes (ADAMS e SHANK, 1959).

Aparentemente, os ajustamentos apresentados por determinado genótipo, como resposta a pressões ambientais distintas, constituem uma caracteristica muito singular, conforme se verifica por padrões diversos de comportamento manifestados por genotipos estreitamente relacionados (HANSON, 1970). Em termos genéricos, pode-se definir estabi lidade fenotipica como sendo a capacidade de um individuo ou população em produzir uma pequena variação de fenótipos em diferentes ambientes, ou seja, de apresentar um comportamen- 
to altamente previsivel independentemente da qualidade dos estimulos ambientais (LEWIS, 1954 e MARIOTTI et alii, 1976).

\subsubsection{Métodos utilizados na avaliação da estabilida de fenotipica}

FISHER e MACKENZIE (1923) foram os primeiros a reconhecer a existência de interaçóes entre genótipos e fa tores ambientais, em trabalho onde se considerou respostas à adubação por parte de diferentes cultivares de batata. Coube a YATES e COCHRAN (1938), entretanto, o emprego inicial de metodologia apropriada para a decomposição da interaça genótipos $x$ ambientes, em estudo envolvendo materiais cultivados em diversos anos e locais, consistindo o método em determinar, para cada cultivar, uma regressão linear da produção em relação à média de produção de todos cultivares em ca da ambiente. Esse procedimento serviu de suporte ao desenvolvimento de outros métodos relacionados a estimativas de parāmetros da estabilidade fenotipica em plantas. As idéias destes autores, porém, só foram aceitas algumas décadas mais tarde, quando FINLAY e WILKINSON (1963) aplicaram a mesma me todologia básica na avaliação da estabilidade de produção de diversos cultivares de cevada, em värios locais e anos. Nes te procedimento de análise os indices mais importantes compreenderam o coeficiente de regressão linear (b) e a média de produção varietal com base em todos os ambientes. o cálculo de b considerou, em cada ambiente, a produção média de cada cultivar como variável dependente e a média de todos cultivares como variável independente. A produção média de todos cultivares, em cada ambiente, permitiu o estabelecimen to de uma graduaçà quantitativa dos ambientes. Definiu-se que cultivares com valores de b próximos de 1,0 possuem esta bilidade média. Dentre estes, aqueles com alta produção média relacionar-se-iam a uma capacidade geral de adaptação, 
enquanto que aqueles com baixa produção média indicariam má adaptação. Cultivares com valores de b superiores a 1,0 foram tidos como mais sensiveis a modificações ambientais, por conseguinte manifestando estabilidade inferior à média e melhor adaptaça a ambientes favoráveis. Valores de b inferio res a 1,0 , por outro 1 ado, foram considerados como caracteristicos de cultivares com estabilidade superior à média, me nos vulneráveis a flutuações ambientais, sendo, desse modo, melhor adaptados a ambientes desfavoráveis à produção. Valo res de b iguais a zero estariam associados a uma estabilidade fenotipica absoluta. Segundo FInLAY e WILKINSON (1963), um cultivar ideal seria caracterizado por um potencial máximo de produção no ambiente mais favorável e estabilidade fenotí pica absoluta.

EBERHART e RUSSEL (1966) desenvolveram um método, para determinação da estabilidade fenotípica, semelhan te ao de FINLAY e WILKINSON (1963), fornecendo, contudo, um parâmetro de estabilidade adicional, caracterizado pelos des vios da regressão $\left(\sigma_{\mathrm{d}}^{2}\right)$. No presente modelo a estabilidade de cada cultivar foi determinada, portanto, em função da pro dução média, coeficiente de regressão e desvios da regressão. Os referidos autores estabeleceram como ideal um culti var que apresentasse alta produção média, coeficiente de regressão igua 1 a 1,0 e desvios da regressão o mais próximos possiveis de zero. Cultivares com coeficientes de regressão superiores ou inferiores a 1,0 seriam melhor adaptados a ambientes favoràveis ou desfavoràveis, respectivamente.

TAI (1971), por sua vez, propôs uma metodologia de análise da estabilidade na qual o efeito da interaça genótipo $x$ ambiente de um cultivar foi decomposto em uma res posta 1 inear aos efeitos ambientais, medida pelo parámetro estatistico $\alpha_{i}$, e em desvios dessa resposta linear, medidos pelo parāmetro estatístico $\lambda_{i}$. 0 parâmetro $\alpha_{i}$ foi estimado 
pela covariância entre os efeitos de ambientes e os efeitos da interação genótipos $x$ ambientes, dividida pela variância dos efeitos ambientais, enquanto que $\lambda_{i}$ foi estimado pela ra zão entre a variância dos desvios da resposta linear e a variāncia do erro associado aos efeitos da interacão genótipos $x$ ambientes. Um cultivar perfeitamente estável foi defi nido por $\alpha=-1,0$ e $\lambda=1,0$, a passo que um cultivar com es tabilidade média teria $\alpha=0,0$ e $\lambda=1,0$.

PLAISTED e PETERSON (1959) planejaram um estü do, envolvendo cultivares de batata, no qual dados de producão obtidos em diferentes locais foram submetidos inicialmen te a uma análise conjunta da variancia, visando verificar a significāncia da interação cultivares $x$ locais. A seguir, considerando a existência de interação significativa, foram realizadas anảlises conjuntas da variāncia para cada combina cão de cultivares tomados dois a dois, com base em todos os locais, obtendo-se uma estimativa dos componentes da variância da interaça cultivares $x$ locais relativos a cada par de cultivares. A média aritmética dessas estimativas foi calcu lada para todos os pares tendo um cultivar em comum. o cultivar relacionado ao menor valor médio foi identificado como o mais estável, dada sua menor contribuição na interação cu 1 tivares x locais. O inconveniente deste método é exigir um grande nümero de anälises em situaçoes onde são muitos os ge notipos avaliados.

PLAISTED (1960) sugeriu a realizaçãode anälises conjuntas da variancia, omitindo em cada uma, sucessivamente, um dos cultivares presentes, obtendo-se diversas esti mativas da interação cultivares $x$ ambientes. A magnitude deste componente indicaria a estabilidade do cultivar suprimido, sendo maís estável o cultivar ausente da anàlise em que o valor da interaça fosse mais elevado. Esta técnica, a exemplo da anterior, é muito trabalhosa quando se conside- 
ra um grande número de cultivares.

BUCIO ALANIS (1966) desenvolveu um modelo especifico para um par de linhas puras, no intuito de estimar os efeitos genético, ambiental e a interação entre os mesmos, observando uma relação 1 inear entre a interação genótipos $x$ ambientes e o efeito ambiental. Posteriormente, o método foi adaptado para o estudo da geração $F_{1}$ resultante do cruzamento entre duas 1 inhagens (BUCIO ALANIS e HILL, 1966), bem como da geração $F_{2}$ e de retrocruzamentos (BUCIo ALANIS et alii, 1969). Trabalho efetuado por PERKINS e JINKS (1968), por sua vez, permitiu que a técnica fosse estendida para diversas linhas puras e descendências $F_{1}$ produzidas de seus cruzamentos. Em todas essas situações os resultados obtidos indicaram que as magnitudes das interações genótipos $x$ ambientes são uma função linear dos efeitos ambientais.

HANSON (1970) apresentou um método no qual a estabilidade de um genótipo foi avaliada com base em sua posição dentro de um espaço, cuja origem estaria associada a um genótipo estävel. Essa medida de estabilidade fenotipica, conforme o autor aqui referido, também poderia ser obtida pela combinação de informações provenientes da análise de regressão e de seus desvios.

Wricke, citado por JoWETT (1972),

OL IVEIRA

(1976) e BECKER (1981), definiu um parâmetro de estabilidade que denominou ecovalência, calculado através da partição da soma de quadrados da interação genótipos $x$ ambientes nos com ponentes devidos aos genótipos isolados, de modo a verificar a contribuição de cada um na interação.

St-PIERRE et a Iii (1967) estabeleceram a esta bilidade de um genótipo em termos de porcentagem de adaptabi lidade, sendo esta referente ao número de ambientes nos quais seu comportamento se mostrasse superior ao comportamen 
to médio de todos os genótipos do conjunto, expresso como uma porcentagem do nümero total de ambientes considerados.

Quanto ao método conhecido por tradicional es te se baseia na decomposição das somas de quadrados devidas a ambientese cultivares $x$ ambientes, provenientes de uma análi se conjunta, nos efeitos de ambiente dentro de cada cultivar, os quais são utilizados como medida da estabilidade (OLIVEIRA, 1976 e SERAPHIN, s.d.).

OLIVEIRA (1976), considerando dados de produção de milho, provenientes de ensaio envolvendo quinze culti vares e treze ambientes, comparou seis métodos de determinação da estabilidade, a saber: a . tradicional, b. Plaisted e Peterson, c. Wricke, d. Finlay e Wilkinson, e. Eberhart e Russel e f. Tai. De um modo geral houve concordāncia entre os resultados obtidos com os diferentes métodos, muito embora os procedimentos metodológicos de Finlay e Wilkinson, bem como de Eberhart e Russel, tenham sido mais informativos, pois, além de estimarem a estabilidade absoluta, avaliaram a estabilidade média, considerando-a sob uma forma dinâmica, por variar de acordo com a capacidade dos ambientes em proporcionar altas ou baixas produtividades. JOWETT (1972) citou que o modelo de Eberhart e Russel é preferivel ao de Finlay e Wilkinson, devido à sua natureza mais explicita, exceção feita àquelas situações em que se verificam diferenças de produção acentuadas entre os cultivares, quando, então, é mais indicada a anàlise com base em uma escala logaritmica, conforme o método proposto por Finlay e Wilkinson.

Diversos autores julgaram os desvios da regressão como sendo o parāmetro de maior importāncia na ava1 iação da estabilidade, enquanto que o coeficiente de regres são foi tido como um paràmetro indicador da adaptabilidade do genótipo, juntamente com sua média fenotipica (BREESE, 1969 ; SAMUEL et alii, 1970; PARODA e HAYES, 1971; BILBRO e 
RAY, 1976; BONATO, 1978). BILBRO e RAY (1976) comentaram que o coeficiente de determinação $\left(R^{2}\right)$, a exemplo dos desvios da regressão, também pode ser utilizado como paràmetro de avaliação da estabilidade, sendo de fácil cälculo e inter pretação, independente das unidades de medida e, além disso, diferenças entre valores de $\mathrm{R}^{2}$ podem ser determinadas estatisticamente. MARIOTTI et a $i i$ (1976), em estudo conduzido com cana-de-açücar, empregaram o coeficiente de determinação como uma das estimativas da estabilidade.

A maioria dos métodos propostos para determinação da estabilidade fenotipica procura explicar a interação genótipo $x$ ambiente através de regressões lineares do comportamento dos diferentes genótipos avaliados sobre uma medida do ambiente. Nem sempre, porém, a interação genótipo $x$ ambiente pode ser satisfatoriamente representada como uma função linear do ambiente, verificando-se que quando os ambientes desviam-se muito de uma condição ótima a produtivida de de um conjunto de genótipos apresenta uma relação quadràtica e não linear, sendo que tanto nos ambientes sub-ótimos como supra-ötimos os rendimentos são baixos e se justapõem (KNIGHT, 1970). Tais observações foram confirmadas por EASTON e CLEMENTS (1973), os quais observaram que com o trigo condições supra-ōtimas de nitrogēnio levarama respostas não 1 ineares, no que se refere à interação genótipo $x$ ambien te. VERMA et alii (1972), a seu turno, constataram, para vä rias caracteristicas de soja, que a interação genótipo $x$ ambiente possui uma natureza predominantemente não 1 inear, podendo esse tipo de resposta ser conseqüēncia da limitada adaptação dessa cultura.

Outro aspecto a ser considerado é o fato de que os modelos 1 ineares partem do pressuposto de que seus efeitos são aditivos, cabendo salientar que o efeito multiplicativo dos ambientes sobre os genótipos, como fonte de in 
teração, tem sido pouco considerado pelos melhoristas de plantas, muito embora determinados resultados experimentais apresentem evidências de sua existência, tais como a maior diferença entre genótipos em ambientes favoráveis, correlação positiva entre médias e coeficientes de regressão dos cultivares, e associação entre médias e variâncias, conforme CHAVES (1982). Com base no exposto, o referido autor aplicou em dados de soja, trigo, mandioca, milho e feijão, um modelo não-linear desenvolvido por VENCOVSKY e GERALDI (1977), que é multiplicativo para os parāmetros genético e ambiental, constatando que os efeitos dos ambientes sobre os genótipos de milho e feijão analisados foram, de certo modo, multiplicativos.

\subsubsection{Estabilidade fenotīpica e producão agrícola}

A obtenção de materiais estáveis, per se, não constitui interesse em agricultura, devendo-se observar também sua produção em termos quantitativos assim como qualitativos, em se tratando de culturas, a exemplo dos citros, onde a qualidade do produto é fator limitante. o melhorista, além disso, deve procurar desenvolver materiais adaptados ao sistema de cultivo para o qual se destinam, ou seja, ao nivel tecnológico a que serão submetidos. Considerando o mode 10 de EBERHART e RUSSEL (1966), um cultivar com bom rendimen to médio, coeficiente de regressão próximo de zero e desvios da regressão nulos, seria especifico para ambientes pobres, isto é, para uma agricultura de poucos recursos, segundo PALOMO G. e MOLINA G. (1975). Genótipos desse tipo, que manifestam comportamento constante em todos ambientes, entretanto, não respondem a condições mais favorāveis de cultivo, sendo contra-indicados para uma agricultura moderna, altamen te tecnificada, que exige, portanto, cultivares com elevada produtividade média, desvios da regressão iguais a zero e 
coeficientes de regressão superiores a 1,0 , conforne $(1972)$.

Melhoristas e geneticistas geralmente conside ram que quanto melhor for o ambiente maiores serão as diferenças entre genótipos, facilitando a identificação daqueles de comportamento superior. BUCIO ALANIS e HILL (1966), por outro 1 ado, comentam que sob certas circunstancias a seleça efetuada em ambientes pobres pode ser melhor sucedida, exemplo de situações onde o interesse recai sobre genótipos portadores de caracteristicas particulares, tais como resistência à seca, pragas e doenças, toleräncia à salinidade, en tre outras. Ocorre, todavia, que o ideotipo de plantas adap tadas a condições ambientais diversas é de dificil definição, visto que genótipos dotados de maior estabilidade podem apresentar mecanismos fisiológicos e padrões de desenvolvimento bastante distintos entre si, ao conträrio do que se verifica para grupos de genótipos adaptados a ambientes especi ficos, nos quais se observam fatores morfológicos e fisiológicos em comum (FINLAY e WILKINSON, 1963). Existem evidências indicativas de que a estabilidade fenotipica seja um caràter herdável, passivel, portanto, de ser incorporado em materiais comerciais, sendo provável que todos os tipos de ação gēnica estejam envolvidos (EBERHART e RUSSEL, 1969). Sua natureza, ao que parece, é poligēnica, conforme observações realizadas nos gèneros Primula e Petunia (MATHER, 1953) e em Zea mays L. (VENCOVSKY, 1978). Considerando-se os parâmetros de estabilidade definidos por EBERHART e RUSSEL (1966), os desvios da regressão, aparentemente, estão mais fortemente associados às constituições genéticas dos materiais, em comparação com os coeficientes de regressão, como constatado com o milho, por esses autores, e com o trigo, por BúsH et a $i$ i (1976). Desse modo, conforme salientado por EBERHART e RUSSEL (1966), tendo-se em vista que a estabilidade è uma ca racteristica herdável, avaliações preliminares em materiais 
genéticos poderiam ser dirigidas para a identificação de genótipos estáveis, a partir dos quais seriam selecionados, posteriormente, tipos de comportamento superior.

ALLARD e BRADSHAW (1964) citaram que o tamponamento de um cultivar, no que se refere à sua insensibilida de frente a variações ambientais, pode se dar a nivel indivi dual ou populacional. Em espécies autógamas é comum a obten ção de cultivares estáveis com base em misturas de linhas pu ras, verificando-se, nesses casos, um tamponamento a nivel populacional, a exemplo do que foi observado com a aveia (JENSEN, 1952 ; FREY e MALDONADO, 1967; PFAHLER e LISKENS, 1979), soja (PROBST, 1957) e Phaseolus lunatus (ALLARD, 1961). Nem sempre, porëm, o desenvolvimento de multilinhas conduz a uma maior estabilidade, conforme constatado por BUSH et a $i$ i (1976) com o trigo. A esse respeito, PFAHLER e LISKENS (1979) comentaram que a principal dificuldade no estabelecimento de tais populações consiste na seleção de linhas puras que em competição se complementam mutuamente quanto a respos ta a variações ambientais e que, uma vez combinadas, satisfa çam às exigências de uniformidade. Resultados favoráveis po dem ser alcançados com maior facilidade mediante a seleção exclusiva de linhas puras altamente produtivas, tomando-se por referéncia o fato de que a produça de uma linha pura apresenta correlação positiva com sua estabilidade, segundo observações realizadas com Avena byzantina C. Koch (PFHALER, 1972 ).

Cultivares estáveis podem, igualmente, ser ob tidos com base na heterozigosidade, segundo mencionado em item anterior, sendo esse processo välido tanto para espëcies alógamas como autógamas. Finlay, citado por BUSH et arii (1976), constatou que populações heterozigotas de cevada, resultantes de um cruzamento diálélico, mostraram maior estabilidade que as 1 inhagens parentais, sendo essa superio- 
ridade mais expressiva em ambientes desfavoráveis. Com o sorgo, populações constituidas por misturas de híbridos tēm se mostrado mais produtivas e estáveis que os parentais homo zigotos (REICH e ATKINS, 1970; JOWETT, 1972; PATANOTHAI e ATKINS, 1974), havendo evidéncias de que hibridos triplos apresentam maior estabilidade que hibridos simples e niveis de produção compativeis aos destes ültimos (JowEtT, 1972 e PATANOTHAI e ATKINS, 1974). Situação semelhante tem sido ve rificada com o milho, dada a existēncia de resultados indica tivos de que hibridos triplos e duplos manifestam menor inte ração genótipo $x$ ambiente em comparação com híbridos simples (SPRAGUE e FEDERER, 1951; EBERHART et ali $i$, 1964; EBERHART e RUSSEL, 1969). Considerando-se, porém, a maior variāncia ge nética presente entre hibridos simples, que entre hibridos duplos e triplos de milho, conforme demonstrado por COCKERHAM (1961), e tendo-se em vista que a estabilidade é um caráter herdável, hibridos simples estáveis e altamente produtivos apresentam, potencialmente, maior valor comercial que os demais tipos hibridos (EBERHART e RUSSEL, 1969). Evidēncias fa voráveis à estas observações foram obtidas por NASPOLINI Fi1ho (1975), constatando este autor que hibridos simples e compostos de milho tenderam a uma maior estabilidade, relati vamente aos caracteres peso de espigas e peso de grãos, em comparaça com as variedades e hibridos duplos avaliados.

Cultivares perfeitamente estáveis provavelmen te não existam, devendo o melhorista satisfazer-se com niveis médios de estabilidade (TAI, 1971). Além disso, ao se aplicar um método de avaliação da estabilidade fenotípica, de ve-se ter em mente que a média das expressões fenotípicas re lacionadas a um determinado genótipo depende da população de ambientes sobre a qual foi obtida. O melhorista reconhece esse fato ao depreender que uma 1 inhagem, hibrido ou cultivar é bem adaptado a uma categoria de ambientes, mas não ó a outra. De maneira semelhante, o valor de um ambiente, ou 
de uma classe de ambientes, depende da população de genótipos com base na qual foi medido. Assim sendo, nenhuma conclusão a respeito da estabilidade fenotipica de caracteristi cas quantitativas terá muito sentido sem que se especifique, de forma razoavelmente concisa, a população genötipos-ambien tes para a qual esse tipo de estudo foi efetuado (COMSTock e MOLL, 1963; KNIGHT, 1970; EASTON e CLEMENTS, 1973; MARIOTTI et alii, 1976).

Os diversos estudos sobre estabilidade fenotí pica, até aqui apresentados, referiram-se à adaptabilidade de cultivares a variações ambientais de certo modo previsiveis, visto que relacionadas a diferenciações de caráter espacial, as quais podem ser influenciadas pelos sistemas de cultivo empregados em cada situação particular. Nestes casos, portanto, a caracterização de cultivares estáveis refle te, em parte, respostas a uma agricultura mais ou menos tecnificada, a depender de uma melhor adaptaça a ambientes mais ou menos favoráveis, respectivamente. Tais metodologias, entretanto, também se aplicam às condições em que as variações ambientais são de natureza temporal, a exemplo do que se verifica em culturas perenes, onde as avaliações são efetuadas ao longo de vários anos, compreendendo, porém, um espaço fixo. Estudo dessa natureza foi realizado por KALIL Filho (1982), no intuito de avaliar a estabilidade de produção de clones de seringueira com base em um local e um perío do de oito anos, abrangendo a fase de crescimento dos materiais, tornando, assim, os padrões de resposta às variaçós de ambiente (anos) parcialmente confundidos com as velocidades de crescimento e de aumento de produção. Em circunstāncias como esta os resultados obtidos não devem ser associados a níveis de tecnificação mais ou menos elevados, uma vez que as variáveis ambientais são imprevisíveis, emsua maioria. 
terminação dos efeitos de porta-enxertos sobre a estabilidade fenotipica em citros, ao longo de diversos anos de cultivo, os conceitos e métodos considerados devem, conseqüentemente, ser empregados criteriosamente, de maneira a permitir uma interpretação adequada dos resultados provenientes das anälises realizadas. 


\section{MATERIAIS E METODOS}

\subsection{Material botãnico}

O material utilizado foi constituido por combinações de um clone nucelar de laranja 'Natal' com cinco porta-enxertos, a saber: 1 imões 'Cravo', 'Rugoso da Flörida' e 'Rugoso FM', laranja 'Caipira' e tangerina 'Dancy'. Para identificação da terminologia cientifica dos materiais discriminados, consultar glossärio (päg. 101).

\subsection{Local do experimento}

o experimento foi instalado no Centro Nacional de Pesquisa de Mandioca e Fruticultura - CNPMF, da Empre sa Brasileira de Pesquisa Agropecuäria - EMBRAPA, localizado no municipio de Cruz das Almas, Recôncavo Baiano, nas coordenadas geogräficas $39^{\circ} 6^{\prime} 23^{\prime \prime}$ de longitude oeste e $12^{\circ}$ 40' 39" de latitude sul, com altitude em torno de $225 \mathrm{~m}$. 


\subsection{Clima e solo}

o clima da região, conforme classificação de küppen, é do tipo Am, quente e úmido, com estação seca compensada por totais elevados de precipitação. Segundo dados dos postos agrometeorológicos da Escola Agronômica da Bahia e do CNPMF, relativos ao período 1949-1981, as normais clima tológicas do citado município são: $23,5^{\circ} \mathrm{C}$ de temperatura, $82 \%$ de umidade relativa do ar (médias anuais) e $1136 \mathrm{~mm}$ de precipitação pluvial (total anual). Quanto aos dados climatológicos específicos aos anos abrangidos pelo presente estu do consultar Tabela Ap.1 (pág. 109).

No que se refere ao solo, este foi classifica do como latossolo vermelho-amarelo distrófico, coeso, A mode rado textura argilosa, fase floresta subperenifolia relevo plano (EMBRAPA/SNLCS, 1977 ).

\subsection{Plano experimental}

0 pomar foi instalado em 1965, obedecendo a um delineamento experimental em blocos casualizados, com cin co repetições, três plantas por parcela, em espaçamento de $7 \mathrm{~m} \times 7 \mathrm{~m}$. Os dados de produção, aqui considerados, foram tomados durante o período de 1970 a 1980 , sendo expressos em kg de frutos por planta. As colheitas das safras principais concentraram-se entre os meses de agosto e novembro. Quanto aos dados de vigor estes foram obtidos nos anos de 1965 , $1969,1975,1977$ e 1980 , compreendendo mensurações da circun ferência da copa (terço inferior da copa), altura da planta e diâmetro do tronco ( $30 \mathrm{~cm}$ acima do nível do solo). Essas determinações foram efetuadas mediante o emprego de uma trena de pano, régua e paquímetro, com,graduação até cm, respectivamente. Avaliações relativas à qualidade dos frutos 
foram realizadas no período de 1976 a 1980 , estando as plantas com idade acima de 10 anos e apresentando, portanto, fru tos com características bem definidas. As variáveis analisa das incluiram peso, altura, diâmetro e espessura da casca dos frutos, porcentagem de suco, acidez, sölidos solüveis e relação acidez/sólidos solúveis, sendo tais determinações efetuadas sempre por ocasião da colheita principal, com base em amostras de 10 frutos por parcela, obtidas ao redor das copas. O peso dos frutos foi identificado através de uma ba lança comercial com capacidade para $10 \mathrm{~kg}$. Os dados de altura, diâmetro e espessura da casca dos frutos foram obtidos com base no uso de um paquímetro graduado até mm. A quantidade de suco foi estabelecida pela diferença entre os pesos dos frutos e do bagaço, transformada em porcentagem. A acidez foi determinada pelo método de MENDES (1936) e os sólidos solüveis através de areômetro de brix, aferido para temperatura de $20^{\circ} \mathrm{C}$.

Foram executados tratos culturais rotineiros visando o controle de pragas, doenças e ervas daninhas, assim como a fertilização do solo. A área experimental não recebeu irrigação.

\subsection{Anāitises estatísticas}

Os dados de produção, vigor e qualidade dos frutos foram, inicialmente, submetidos a uma anālise de variância em blocos casualizados com parcelas subdivididas no tempo, tendo-se em vista o fato de que as observações se deram nas mesmas parcelas, com as mesmas combinações copa/porta-enxertos, ao longo de anos sucessivos.

0 modelo matemático considerado foi:

$$
Y_{i j k}=m+t_{i}+b_{j}+e_{i j}+t^{\prime}{ }_{k}+\left(t t^{\prime}\right)_{i k}+\left(t^{\prime} b\right)_{j k}+e_{i j k}
$$


Onde:

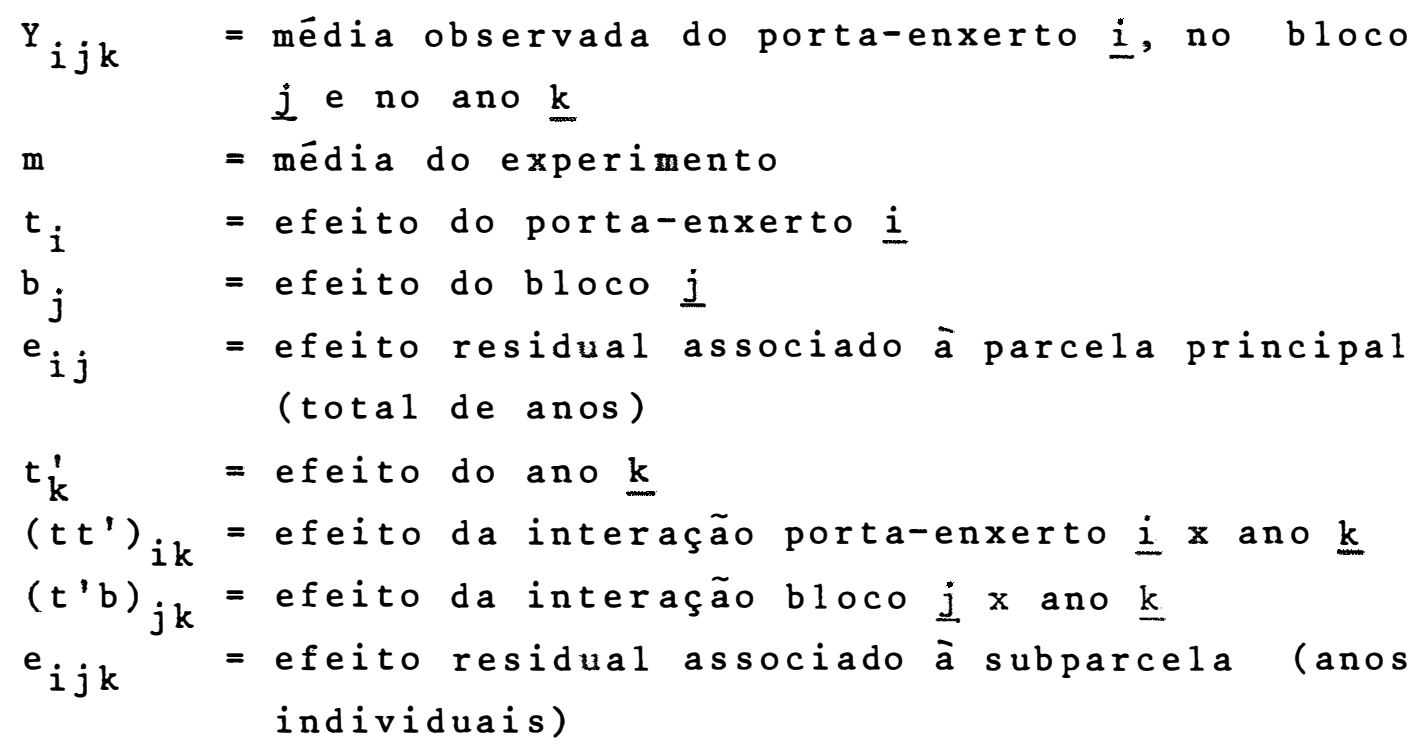
Os efeitos correspondentes à média do experimento e aos porta-enxertos foram considerados como fixos e os demais aleatórios. O esquema da análise, assim como os componentes de variância, são apresentados na Tabela 1 .

As avaliações relativas à estabilidade fenotí pica basearam-se na metodologia proposta por EBERHART e RUSSEL (1966), considerando-se cada ano como um ambiente diferente, sendo as análises efetuadas a partir de médias. Os parâmetros observados nesse estudo compreenderam os coeficientes de regressão linear ( $b$ ), as variâncias dos desvios da regressão $\left(\sigma_{d}^{2}\right)$, assim como as médias fenotípicas observadas para as diferentes combinações copa/porta-enxerto.

$$
\begin{aligned}
& 0 \text { modelo de regressão adotado foi: } \\
& Y_{i k}=\mu_{i}+\beta_{i} I_{k}+\delta_{i k}+\bar{\varepsilon}_{i k}
\end{aligned}
$$

Onde:

$$
\begin{aligned}
& Y_{i k}=\text { média observada do porta-enxerto } \underline{i} \text { no ano } \underline{k} \\
& \mu_{i}=\text { média do porta-enxerto } \underline{i}_{\text {em todos os anos }}
\end{aligned}
$$




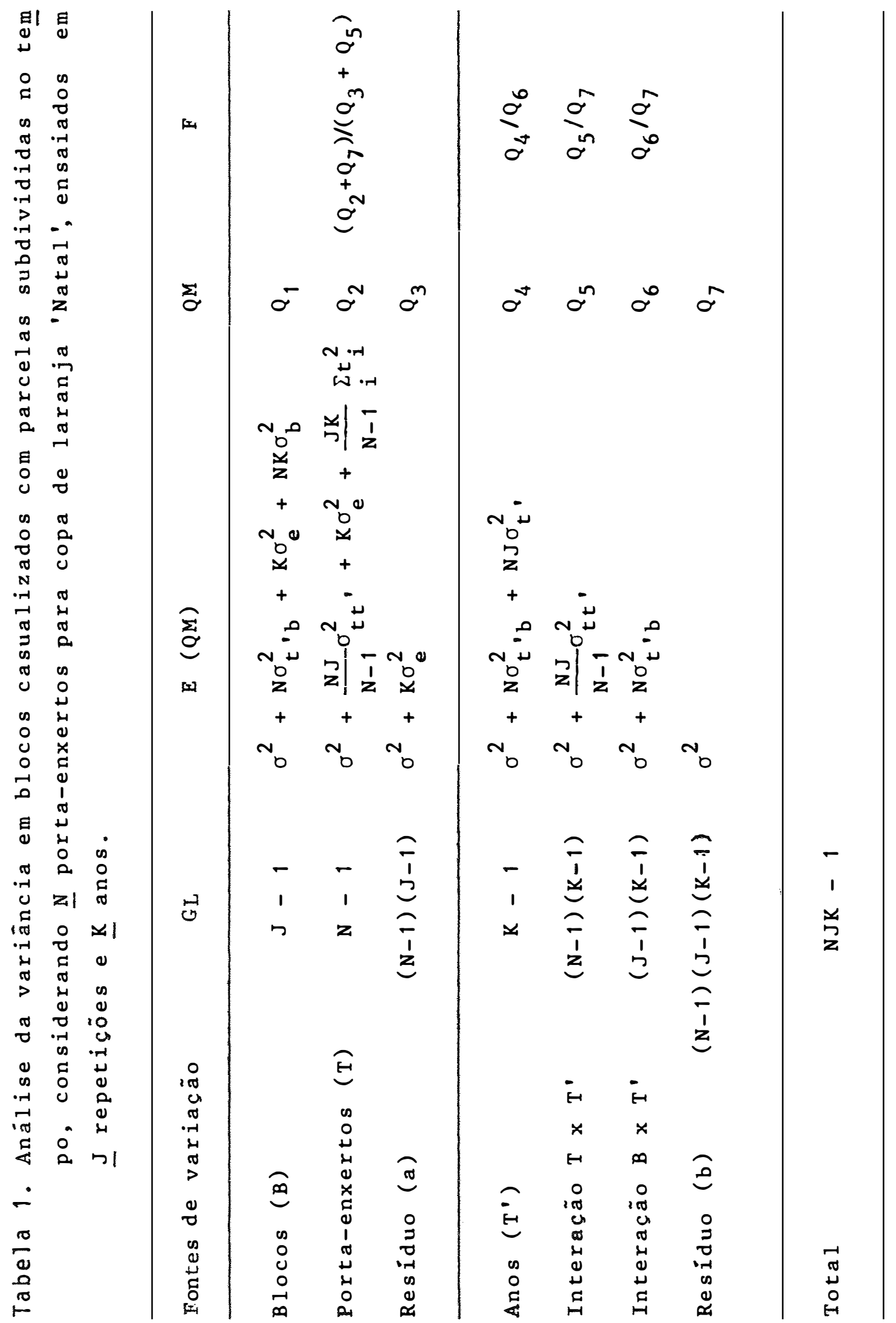


$\beta_{i}=$ coeficiente de regressão que mede a resposta do porta-enxerto $\underline{i}$ à variação dos anos

$\delta_{i k}=$ desvio da regressão do porta-enxerto $\underline{i}$ no ano $\underline{k}$ $I_{k}$ = indice anual, obtido pela diferença entre a média fenotípica de cada ano e a média fenotípica de todos os anos, conforme a expressão:

$I_{k}=\frac{Y \cdot k}{N}-\frac{Y}{N K}$ lembrando que $\underset{k}{\sum} I_{k}=0$

Onde:

$Y_{. k}=$ total do ano $\underline{k}$ em relação a todos os porta-enxertos

$Y=$ total geral

$\mathrm{N} \quad=$ número de porta-enxertos

$\mathrm{K}=$ nümero de anos

$\bar{\varepsilon}_{i k}=$ efeito residual associado à média.

o cälculo do coeficiente de regressão linear

foi obtido por:

$b_{i}=\frac{\sum_{i k} Y_{k}}{\sum_{k} I_{k}^{2}}$ lembrando que $\bar{b}=1,0$

A análise da variância obedeceu à adaptação proposta por BONATO (1978), posteriormente utilizada por SANTOS (1980), que permite decompor a soma de quadrados de anos dentro de porta-enxertos [anos + (anos x porta-enxertos)] nos efeitos lineares e desvios da linearidade, tanto para o conjunto de porta-enxertos estudados, como para cada porta-enxerto particular (Tabela 2). O teste de hipótese da nulidade, relativo aos coeficientes de regressão, $H_{0}=\beta_{1}=$ $=\beta_{2}=\ldots=\beta_{N}$, foi realizado através do teste $F$ referente ao quadrado médio de anos (linear) x porta-enxertos. Os quadrados médios relativos ao efeito linear e aos desvios da 


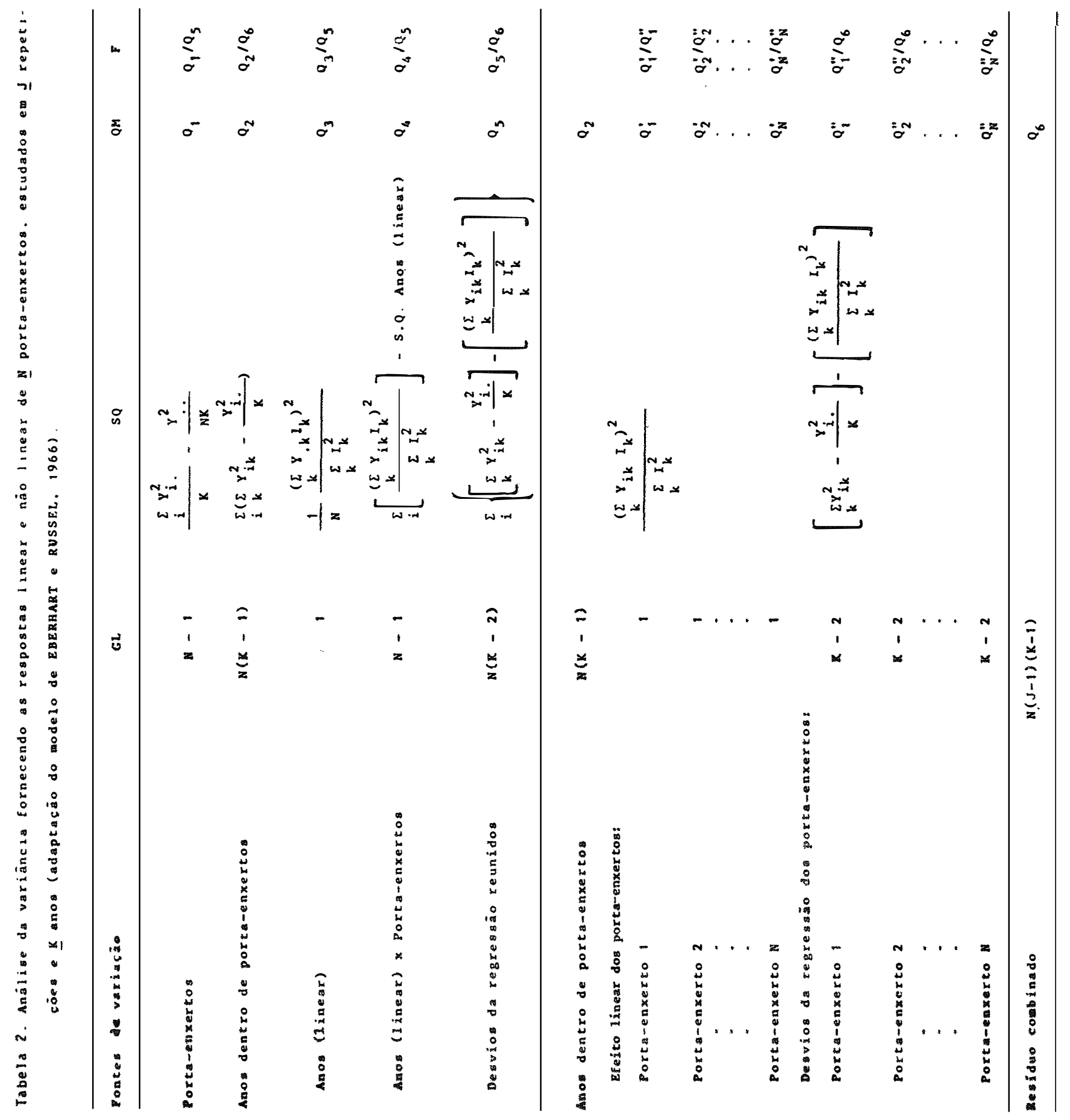


regressão ofereceram, respectivamente, respostas sobre a linearidade e não linearidade de cada porta-enxerto frente às variações ambientais.

o resíduo da anālise da estabilidade proveio da anälise de variância em blocos casualizados com parcelas subdivididas no tempo, resultando da combinação do quadrado médio de blocos $x$ anos com o quadrado médio do resíduo (b), necessāria para testar o quadrado médio de anos dentro de porta-enxertos, assim como os desvios da regressão, conforme apresentado na Tabela 3 .

As variâncias do efeito de anos dentro de cada porta-enxerto (quadrado médio do efeito linear + quadrado médio dos desvios da regressão), bem como dos desvios da regressão, foram submetidas ao teste de homogeneidade de variâncias de Bartlett (SNEDECOR, 1957), no intuito de verificar a necessidade de ajustamentos nos graus de liberdade do efeito de anos dentro de porta-enxertos e dos desvios da regressão reunidos, respectivamente, sendo os mesmos realizados de conformidade com PIMENTEL GOMES (1976).

A hipōtese de que os coeficientes de regressão 1 inear não diferem da unidade foi julgada pelo teste "t" de student, segundo a fórmula:

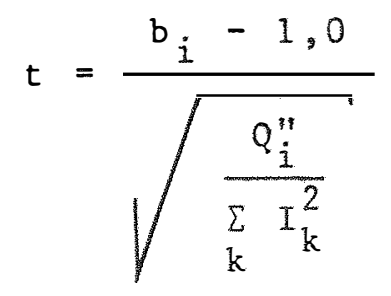

Onde:

$$
\begin{aligned}
& b_{i}=\text { coeficiente de regressão linear do porta-enxerto } \\
& Q_{i}^{\prime \prime}=\text { quadrado médio dos desvios da regressão do porta- } \\
& \sum_{k} I_{k}^{2}=\text { somatória dos quadrados dos indices anuais }
\end{aligned}
$$




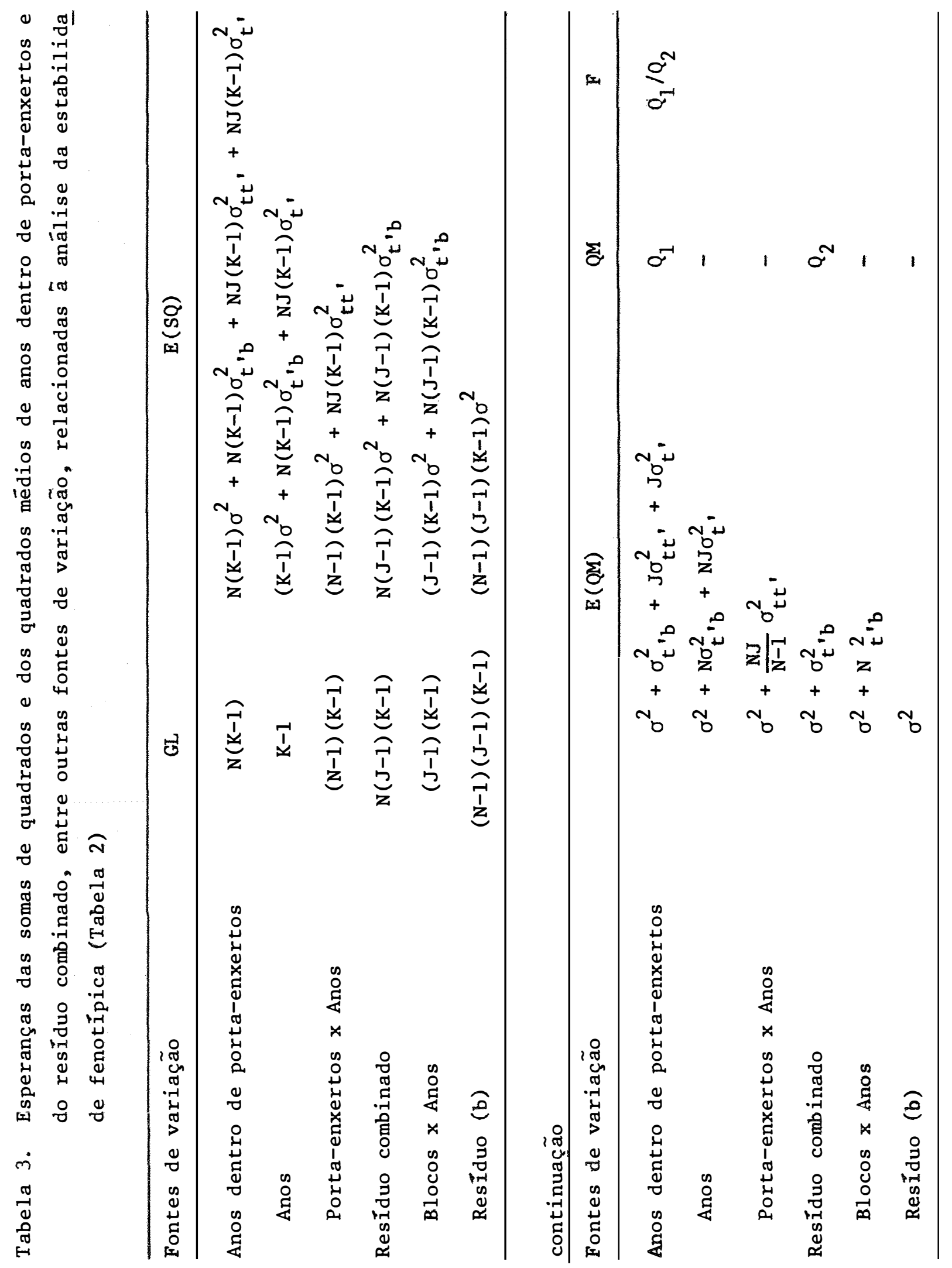


o denominador da expressão ora apresentada de fine o erro do coeficiente de regressão linear (STEEL e TORRIE, 1960).

Visando verificar o quanto da variação total de cada porta-enxerto foi devido aos efeitos lineares, proce deu-se o cälculo do coeficiente de determinação, conforme a expressão:

$$
R_{i}^{2}=\frac{\left(\sum Y_{i k} I_{k}\right)^{2}}{\left(\sum I_{k}^{2}\right)\left[\sum_{k} Y_{i k}^{2}-\frac{k}{\left(\sum Y_{i k}\right)^{2}}\right]}
$$

Onde:

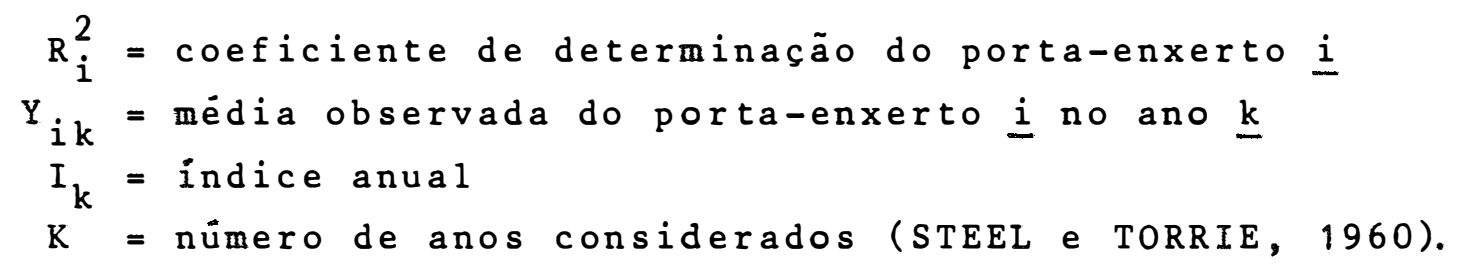

A hipótese de que os eoeficientes de determina cão não diferem de zero foi avaliada pelo teste "t", da maneira que se segue:

$$
t=\frac{R_{i} \sqrt{K-2}}{\sqrt{1-R_{i}^{2}}}
$$

com K-2 graus de 1 iberdade (PIMENTEL GOMES, 1976).

A comparaço das médias fenotipicas dos porta-enxertos foi efetuada através do teste de Tukey, ao nivel de $5 \%$ de probabilidade. Nesse teste o cälculo da DMS ou $\triangle$ (diferenç minima significativa) obedeceu ao seguinte proce- 
dimento:

$$
\Delta=q \frac{s}{\sqrt{r}}
$$

Onde:

$$
\begin{aligned}
q= & \text { valor da amplitude total estudentizada } \\
\mathbf{s}= & \text { estimativa do desvio padrão residual }=\sqrt{Q_{3}+Q_{5}} \\
& \text { sendo que } Q_{3} \text { e } Q_{5} \text { provêm da añise da variāncia } \\
& \text { apresentada na Tabela } 1 \text { (pág. } 33 \text { ) } \\
r= & \text { numero de repeticóes }=\text { nümero de blocos } x \text { nümero de } \\
& \text { anos considerados. }
\end{aligned}
$$

Com o objetivo de verificar a existência de efeitos multiplicativos sobre o comportamento dos porta-enxertos analisados, as médias de producão de frutos foram sub metidas ao modelo não-linear desenvolvido por VENCOVSKY e GERALDI (1977), posteriormente aplicado por CHAVES (1982), sendo o mesmo assim definido:

$$
Y_{i k}=\alpha_{i}\left(1+B_{k}\right)+\bar{\varepsilon}_{i k}
$$

Onde:

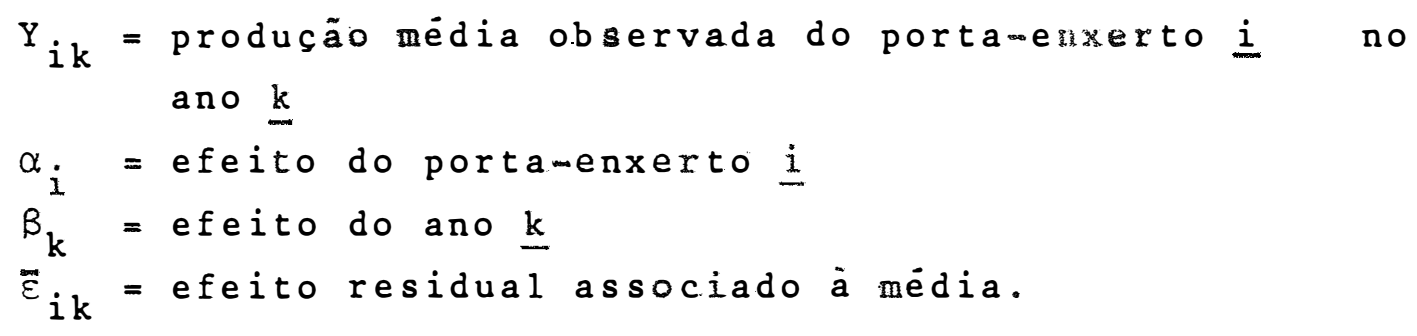

As estimativas de $\alpha_{i} e\left(1+\beta_{k}\right)$ foram obtidas com base nas expressöes:

$$
\hat{\alpha}_{i}=\frac{\sum_{k} Y_{i k}\left(1+\hat{\beta}_{k}\right)}{\sum_{k}\left(1+\bar{\beta}_{k}\right)^{2}}
$$




$$
\left(1+\hat{\beta}_{k}\right)=\frac{\sum_{i k} Y_{i} \hat{\alpha}_{i}}{\sum_{i} \hat{\alpha}_{i}^{2}}
$$

$Y$ A primeira estimativa de $\alpha_{i}$ foi definida por $\frac{. k}{k}$, possibilitando o cālculo da primeira estimativa de $\left(1+B_{k}\right)$. As demais estimativas foram obtidas através de um processo iterativo de equaçóes, que se repetiu até a determi naça de valores estäveis, os quais constituiram as estimati vas procuradas. Obteve-se a seguir as somas de quadrados re lativas aos parámetros principais e aos desvios do modelo, a saber:

$$
\begin{aligned}
& S Q_{\alpha, \beta}=\sum_{i} \bar{\alpha}_{i}^{2} \sum_{k}\left(1+\hat{\beta}_{k}\right)^{2} \\
& S Q_{d}=\sum_{i k} Y_{i k}^{2}-S Q_{\alpha, \beta}
\end{aligned}
$$

A quantificação dos. efeitos multiplicativos

foi realizada com base na expressão:

$$
R_{m}^{2}=\frac{\frac{S Q_{t t^{\prime}}}{r}-S Q_{d}}{\frac{S Q_{t t^{\prime}}}{r}}
$$

Onde:

$$
\begin{aligned}
& \mathrm{R}_{\mathrm{m}}^{2}=\text { coeficiente de determinaçãodos efeitos multiplica- } \\
& \text { tivos detectados pelo modelo } \\
& S Q_{t}, / r=\text { soma de quadrados da interaça entre porta- } \\
& \text {-enxertos e anos, proveniente da anälise da } \\
& \text { variāncia apresentada na Tabela } 1 \text { (pág. 33), } \\
& \text { dividida pelo nümero de repetições } \\
& S Q_{d}=\text { soma de quadrados dos desvios do modelo não } 1 \text { i- }
\end{aligned}
$$




\title{
4. RESULTADOS E DISCUSSÁO
}

\author{
4.1. Produção de frutos
}

As produções médias de frutos obtidas no periodo 1970-1980, com os respectivos indices anuais, calculados com base na metodologia proposta por EBERHART e RUSSEL (1966), são apresentadas na Tabela A.1 (päg. 104). A referi da tabela inclui também as estimativas de $\alpha_{i}$ e $\left(1+\beta_{k}\right)$ rela tivas, respectivamente, aos parāmetros genético e ambiental do modelo multiplicativo sugerido por VENCOVSKY e GERALDI $(1977)$.

os indices anuais $\left(I_{k}\right)$, que refletem as diferenças entre as médias dos värios anos compreendidos no estu do da estabilidade fenotipica, variaram entre um minimo de $-106,12$, verificado em 1972, a um máximo de 113,18, constata do em 1979. As estimativas dos parámetros anuais $\left(1+\beta_{k}\right)$, concernentes ao modelo não linear considerado, respeitaram a mesma tendéncia observada para os indices anuais, localizando-se entre os 1 imites de 0,3500 e 1,6952, estabelecidos em 1972 e 1979, respectivamente. As referidas variäveis ambientais, com base em raciocinio simplista, refletem condições ecológicas mais ou menos favoràveis à produção de fru- 
tos, segundo a dependência direta de suas magnitudes. A pre sente pesquisa, porëm, envolveu plantas que no princípio das avaliações de produção, apesar de constituirem um pomar com cinco anos de idade, ainda se encontravam em pleno desenvolvimento, de maneira que as variáveis ambientais relacionadas aos anos iniciais desse estudo foram influenciadas pelo aumento dos volumes das copas. Apesar disso, considerando as primeiras observações realizadas, pode-se julgar que os anos de 1971 e 1972, especialmente este ültimo, se mostraram ecologicamente menos favoráveis ao caráter ora analisado. Outro aspecto a ser ponderado é a ocorréncia do fenómeno da alternância de produção, muito comum em citros, afetando o comportamento dos mencionados indices e parâmetros anuais. Esse efeito pode ser visualizado, particularmente, no periodo compreendido entre 1977 e 1980, ocasião em que as plantas já haviam atingido a idade adulta, apresentando volumes de copa praticamente estabilizados. Isto posto, tem-se que as informações oferecidas pelas variáveis ambientais devem ser analisadas com o devido critério, de forma a evitar erros de interpretação.

Os resultados da anàlise da variāncia em blocos casualizados com parcelas subdivididas no tempo, provenientes de onze anos de observações, encontram-se na Tabela 4. O teste $F$ mostrou-se altamente significativo para os efeitos de porta-enxertos e de anos, assim como para as inte rações porta-enxertos $x$ anos $e$ blocos $x$ anos, indicando: $a$. diferenças quanto à produtividade determinada à copa pelos distintos porta-enxertos; b. diferenças entre as condiçóes ambientais relacionadas aos anos abrangidos na anälise; c. diferenças genéticas entre os cinco porta-enxertos, no que se refere às respostas de suas combinaçóes com laranja 'Natal' às variações anuais; e d. alterações no posicionamento dos blocos, quanto aos seus niveis de produtividade ao longo dos anos. As diferenças entre anos, convém reforçar, foram 
influenciadas, em parte, pelo crescimento das plantas na fase inicial das avaliações de produção.

Tabela 4. Anảlise da variāncia em blocos casualizados com parcelas subdivididas no tempo, relativa à producão média de frutos, em kg/planta, considerando cinco porta-enxertos para copa de laranja 'Natal', ensaiados em cinco repeticões e onze anos no Reconn cavo Baiano.

Fontes devariação

GL

QM

B $10 \cos$ (B)

Porta-enxertos

Residuo (a)

\section{4}

4

16

10

40

40

160
$109.398,12 * *$

$4.456,56$

$\begin{array}{llrr}\text { Anos }\left(T^{\prime}\right) & & 10 & 144.323,84 * * \\ \text { Interação } T \times T^{\prime} & 40 & 6.402,69 * * \\ \text { Interação } B \times T^{\prime} & 40 & 3.641,15 * * \\ \text { Residuo (b) } & 160 & 1.400,90\end{array}$

Tota 1

27.4

**: significativo ao nivel de $1 \%$ de probabilidade.

Tendo-seem vista a manifestação de interação a 1 tamente significativa entre porta-enxertos $x$ anos, foi efetuado o estudo da estabilidade fenotípica, de modo a melhor detalhar o comportamento de cada porta-enxerto em combinaça com laranja 'Natal'. Seus resultado's são apresentados na Ta bela 5, de cuja observação se conclui que a maior parte da 
variāncia de anos dentro de porta-enxertos é explicada pela regressão linear, verificando-se que o quadrado médio dos efeitos 1 ineares foi 365,2 vezes superior ao dos desvios da regressão reunidos, o que é confirmado por um coeficiente de determinação dos efeitos 1 ineares $\left(R^{2}\right)$ da ordem de $87,55 \%$, calculado com base na soma de quadrados. Trabalhos conduzidos com Nicotiana rustica (BUCIO ALANIS, 1966; BUCIO ALANIS e HILL, 1966; PERKINS e JINKS, 1968; BUCIO ALANIS et a $i$ i, 1969), Dactylis glomerata (BREESE, 1969), algodão (BILBRO e RAY, 1976), soja (BONATO, 1978) e feijão (SANTOS, 1980) cons tituem, igualmente, exemplos de que a interação genótipos $x$ ambientes pode ser interpretada como uma função 1 inear dos efeitos ambientais. Esse tipo de resposta ao ambiente, contudo, não deve ser generalizado, devido a ocorrēncia de exce coós nas quais tal interaça é de natureza predominantemente não 1 inear, conforme destacado por KNIGHT (1970), VERMA et alii (1972) e EASTON e CLEMENTS (1973).

A partir da anālise da estabilidade pode-se depreender que os porta-enxertos, combinados com laranja 'Na tal', diferiram entre si quanto aos comportamentos linear e não 1 inear, como decorrência dos altos niveis de significância registrados para os componentes da variáncia de anos den tro de porta-enxertos, particularmente aqueles relativos a anos (linear) $x$ porta-enxertos e desvios da regressão reuni dos. A significancia da interaça anos (1inear) $x$ porta-enxertos indicou que os "cavalos" não apresentaram uniformidade de comportamento no tocante às suas reaçós às flutuacões anuais, o que significa, em outras palavras, que seus coeficientes de regressão 1 inear não foram semelhantes. A significāncia dos desvios da regressão reunidos, a seu turno, evi denciou que a previsibilidade de respostas às variacoós anuais, relativamente ao conjunto de, porta-enxertos estudados, sofreu restrições. 
Tabela 5. Análise da variāncia da produção média de frutos, em kg/planta, considerando cinco porta-enxertos pa ra copa de laranja 'Natal', ensaiados em onze anos no Recóncavo Baiano (adaptação do modelo de EBERHART e RUSSEL, 1966).

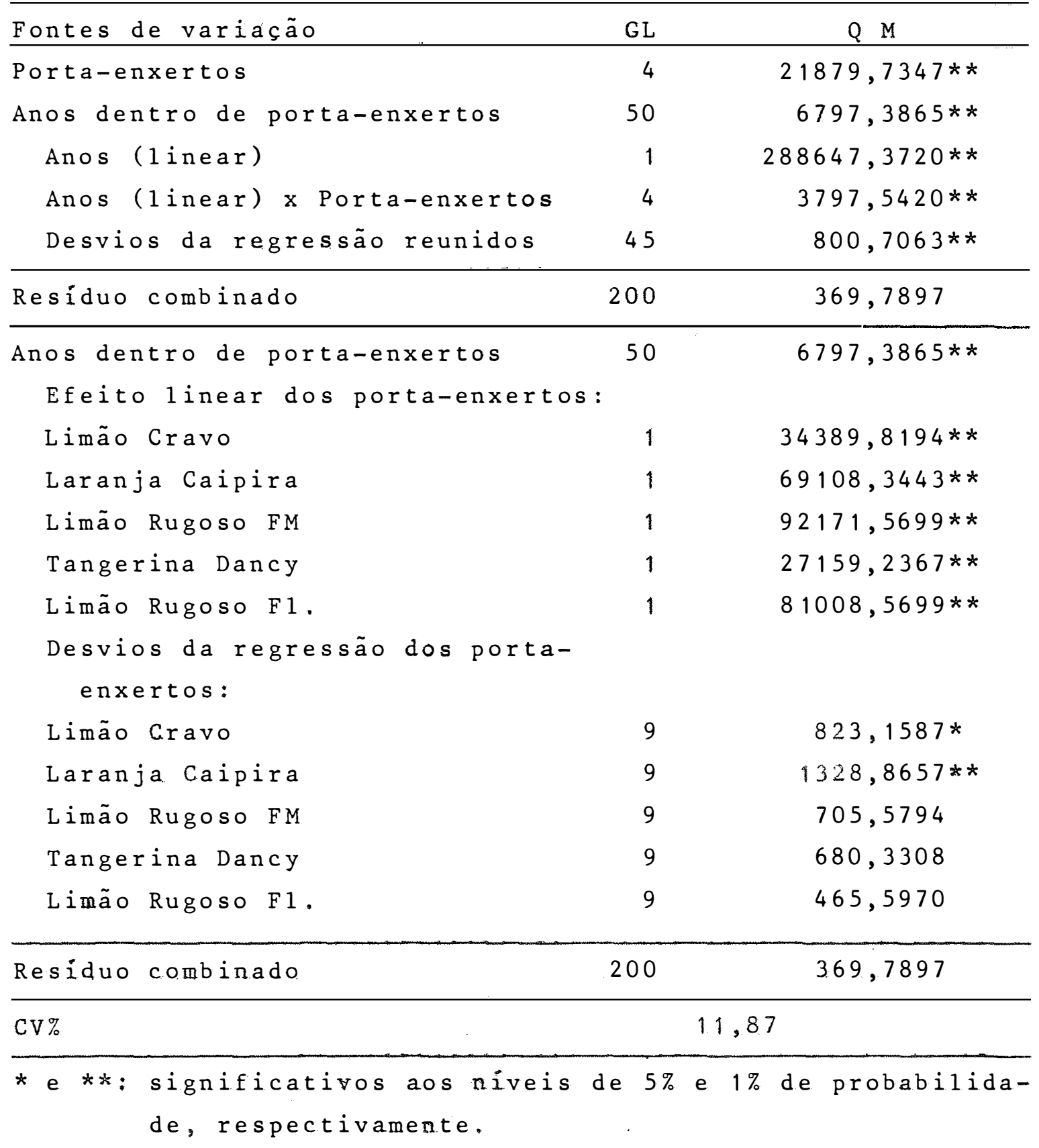


Na segunda parte da Tabela 5 ë apresentada a decomposiça dos efeitos lineares e não lineares para cada porta-enxerto, permitindo, desse modo, uma caracterização in dividual de suas reações às mudanças ambientais. Todos os genótipos expressaram respostas altamente significativas para o efeito linear, sendo estas avaliaçóes efetuadas combase no quociente (teste F) entre as variāncias dos efeitos 1 i near e não linear de cada porta-enxerto. Deve-se ressaltar, porém, que o modelo de anälise estabelecido por EBERHART e RUSSEL (1966) conduz, devido à sua própria estrutura, a uma alta significāncia dos efeitos lineares, fazendo com que os coeficientes de regressão linear distribuam-se em torno do do valor mèdio $\bar{b}=1,00$. O 1 imão 'Rugoso da Flörida', dentre os "cavalos" estudados, foi o que apresentou o maior quo ciente $(173,99)$, enquanto que à tangerina 'Dancy' coube o me nor $(39,92)$. Os referidos quocientesconcordaram, quanto à ordenação de suas magnitudes, com os coeficientes de determi nação $\left(R^{2}\right)$ calculados para cada porta-enxerto, os quais variaram entre os 1 imites de $95,08 \%$ a $81,60 \%$, obtidos, respectivamente, para o limão e a tangerina citados (Tabela 6). Quanto às variāncias dos desvios da regressão, estas foram significativas para o limão 'Cravo' e altamente significativas para a laranja' 'Caipira', enquanto que os demais genotipos näo se desviaram da linearidade, segundo niveis significativos. Esses resultados indicam que, muito embora as inte rações do limão 'Cravo' e da laranja 'Caipira' com os diferentes anos sejam em grande parte explicadas pela regressão inear, os mencionados "cavalos" manifestam, em determinados anos, desvios em relação às respostas esperadas, o que carac teriza a imprevisibilidade de seus comportamentos.

Os coeficientes de regressäo 1 inear, por sua vez, variaram de 0,69 para a tangerina 'Dancy', a 1,26 para o 1 imão 'Rugoso FM', sendo que somente esses valores limites diferiram significativamente de 1,00 , conforme teste $t$ a $5 \%$ de probabilidade (Tabela 6). 
.47.

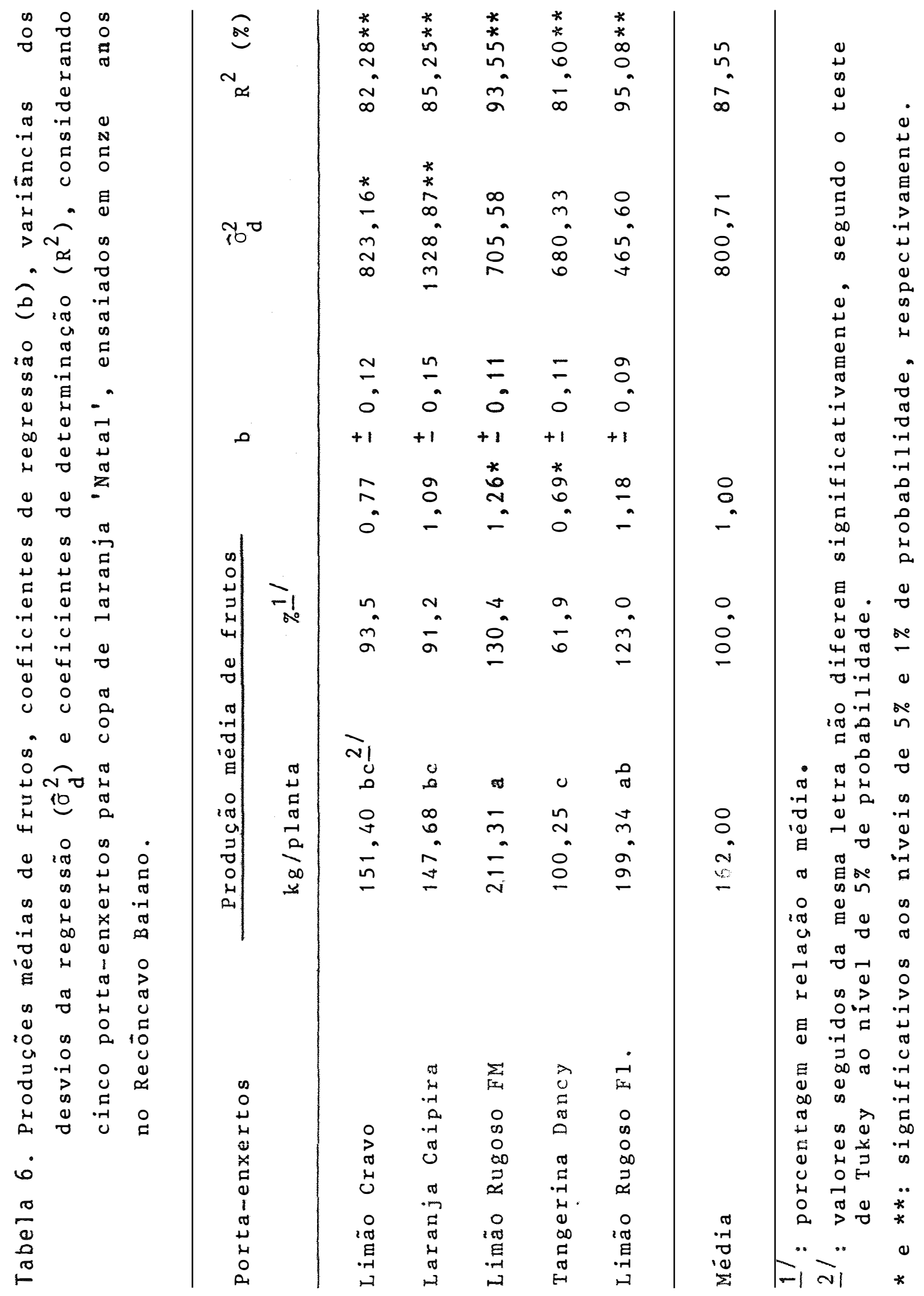


EBERHART e RUSSEL (1966) consideram um cultivar estävel como sendo aquele que possui um b $=1,00$ e $\hat{\sigma}^{2} \mathrm{~d}=$ = 0 . Cultivares que obedecem essas caracteristicas expressam respostas crescentes a melhoria das condiçóes ambientais, além de apresentarem um comportamento previsivel. Essa def 1 nição de estabılıdade ajusta-se perfeitamente às necessidades de uma agricultura moderna, assentada em bases economicas, voltada, portanto, para materiais que a par dos requisi tos mencionados exibem altas produçóes médias. Sob este pon to de vista, o limão 'Rugoso da Flörida', no conjunto de genotipos analisados, foi o que melhor atendeu a todas essas exigéncias, dada sua associação a um elevado potencial produ tivo ( $23,0 \%$ superior à média geral); variáncia dos desvios da regressão não significativa, cujo valor foi o mais baixo dentre os observados; e a um coeficiente de regressão não di ferente de 1,00, pelo teste $t$, indicando sua boa adaptaça à todos os anos (Tabela 6). Outros autores confirmam essa pro priedade do limão 'Rugoso da Flörida', no sentido de induzir alta produtividade às copas citricas (COOK et alii, 1952 ; HEARN et alii, 1974 ; CUNHA Sobrinho et alii, 1978; SOARES Fi 1 ho et ali $i$ 1980; DORNELLES, 1981), muito embora MOREIRA $e^{+}$ alii (1960) tenham apresentado resultados contraditorios a esse respeito. 0 coeficiente de regressão obtido para o 11 mão 'Rugoso da Flórida' ( b = 1, 18) identifica, a principio, uma tendéncia à adaptação a anos ecologicamente mais favoräveis, conforme ilustrado nas Figuras 1 e 2 .

O limão 'Rugoso FM' destacou-se também como um dos porta-enxertos mais recomendáveis para laranja 'Natal', tendo sido aquele que influenciou maior produtividade à copa (30,4\% superior à média geral), alèm de não ter apre sentado desvios significativos com relaçà à linearidade, o que atesta a previsibilidade de seu comportamento. Seu coeficiente de regressão, cujo valor foi significativamente 

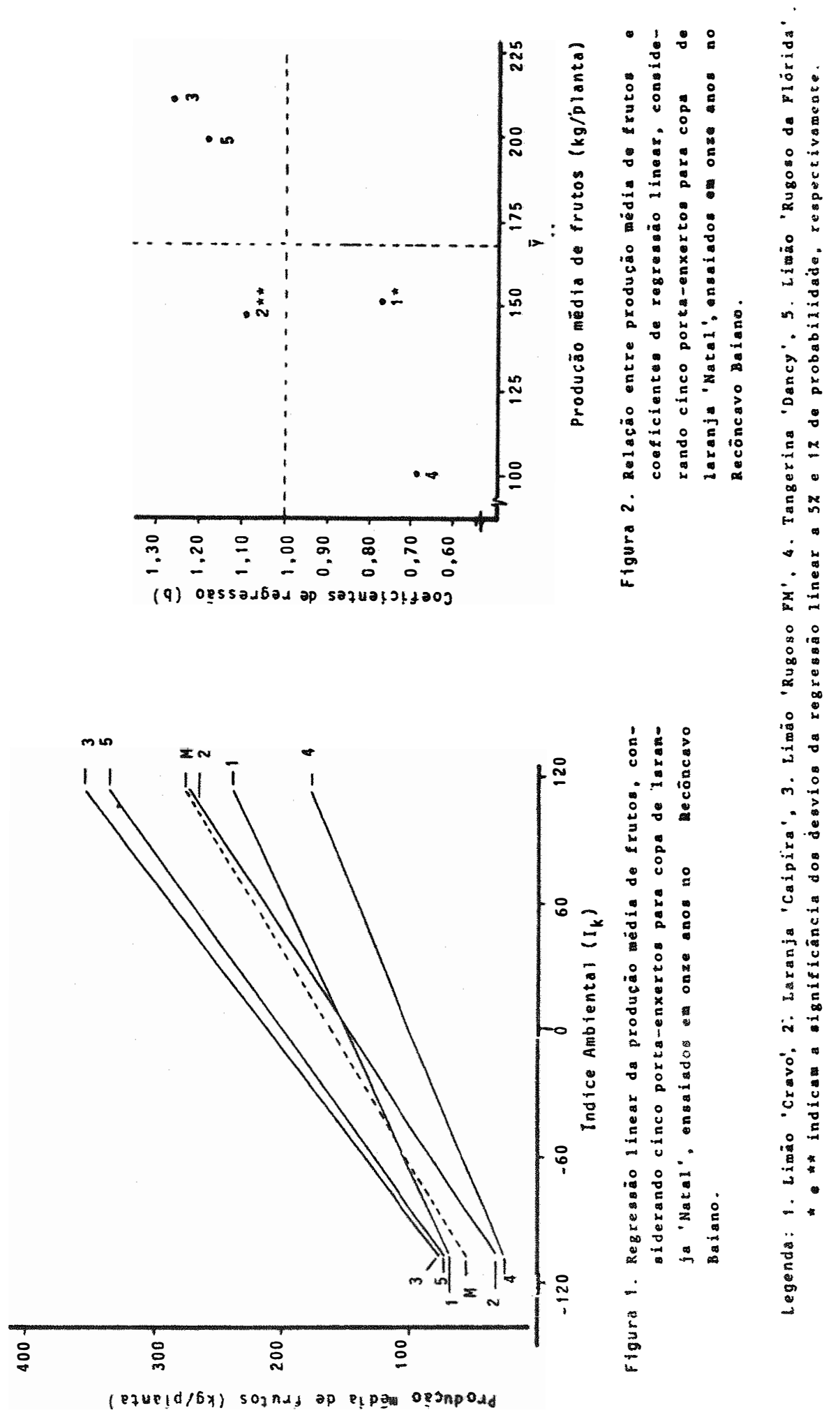
maior que 1,00 , indica uma melhor adaptaça a anos mais favo ràveis (Tabela 6, Figuras 1 e 2). A observação dos dados mé dios de produção dos frutos (Tabela A.1, pág. 104), todavia, revela que tanto esse porta-enxerto como o limão 'Rugoso da Flórida' colocaram-se entre os melhores no decorrer de todos os anos da análise, mesmo naqueles associados aos mais baixos indices anuais, a exemplo de 1971 e 1972 , nos quais alternaram-se como primeiro e segundo melhores "cavalos" em termos de produtividade. Esse comportamento, na realidade, foi conseqüencia dos volumes de copa superiores associados aos referidos genótipos, determinando maiores produçóes por planta. Tais resultados não causam surpresa, uma vez que o limão 'Rugoso FM' é uma seleção do limão 'Rugoso da Flórida', sendo a denominação FM derivada de Fazenda Maravilha, propriedade localizada no Recóncavo Baiano, onde o citado clone foi identificado.

$$
\text { Quanto aos demais "cavalos", o limão 'Cravo' }
$$
e a laranja 'Caipira' apresentaram desvios significativos da linearidade, conforme já mencionado. Seus coeficientes de re gressào nào diferiram significativamente de 1,00 , pelo teste $t$, verificando-se, porém, uma tendēncia do limào 'Cravo' manifestar boa adaptação a anos menos favoráveis, à semelhança da tangerina 'Dancy', cujo coeficiente de regressão foi significativamente inferior a 1,00 , segundo relato anterior. Es ses porta-enxertos determinaram niveis de produtividade infe riores à média geral, em $6,5 \%, 8,8 \%$ e $38,1 \%$, respectivamente para o limão, laranja e tangerina referidos (Tabela 6, Figuras 1 e 2).

os comentärios realizados, relativos à adaptạ ção dos genótipos, restringem-se às suas reações diante de variações temporais, caracterizadas pelas flutuaçóes ecológi cas associadas aos anos incluidos no presente estudo, não re fletindo, portanto, a adaptaça desses materiais a níveis 
.51.

tecnológicos mais ou menos elevados, uma vez que todos os "cavalos" aqui considerados foram submetidos a um mesmo sistema de cultivo.

Considerando-se, agora, o modelo multiplicati vo proposto por VENCOVSKY e GERALDI (1977), com base nas es timativas de $\alpha_{i}$ e $\left(1+\beta_{k}\right)$ e nas produções médias de frutos, apresentadas na Tabela A.1 (päg. 104), obteve-se os valo res referentes à soma de quadrados dos parâmetros principais do modelo $\left(S_{\alpha, \beta}\right)$, bem como à soma de quadrados dos seus des vios $\left(S Q_{d}\right)$, os quais corresponderam a $1,8322 \times 10^{6}$ e $3,851 \overline{1}$ $x 10^{4}$, respectivamente. A partir dessesresultados e da soma de quadrados da interação porta-enxertos $x$ anos, proveniente da análise da variāncia em blocos casualizados com parcelas subdivididas no tempo (Tabela 4, päg. 43) e transformada ao nivel de médias, foi calculado um coeficiente de determina ção dos efeitos multiplicativos identificados pelo modelo não-1inear $\left(R^{2} \mathrm{~m}\right)$. O referido coeficiente indicou que cerca de $25 \%$ da interaça porta-enxertos $x$ anos foi devida a efeitos de natureza não-linear. Esse resultado, apesar de revelar a existência de uma possivel aça multiplicativa dos diferentes anos sobre o comportamento das combinaços copal porta-enxertos analisadas, o que é corroborado pela existência de uma tendência unidirecional entre as estimativas dos coeficientes de regressão e as mëdias fenotíicas observadas ( Tabela 6), deve ser considerado com precauções, tendo-se em vista a identificaça de um certo desajuste dos dados de produção de frutos em relação ao modelo multiplicativo empregado, dada a presença de ligeiras discrepāncias entre as estimativas do parāmetro genético $\alpha_{i}$ e as médias dos respectivos porta-enxertos, especificamente do limão 'Cravo' e da laranja 'Caipira' (Tabela A.1, päg.104), conforme comentärios rea lizados por CHAVES (1982). 


\subsection{Vigor das combinaçōes copa/porta-enxerto}

Os resultados das avaliações de vigor, assim como sua discussão, seräo apresentados de forma a envolver, num só conjunto, os dados de circunferéncia da copa, altura da planta e diàmetro do tronco. Seus valores médios, com os respectivos indices anuais, encontram-se na Tabela A.2 (päg. 105).

Os indices anuais, aqui considerados, refletem, principalmente, as taxas de crescimento das plantas e a fase em que o pomar estabilizou seu desenvolvimento. Confor me se percebe, na Tabela A.2., a taxa de crescimento das com binaçöes citricas foi mais acentuada durante o intervalo 1965-1969, em comparação com aquela relativa a 1969-1975, sen do que após este último ano identifica-se uma tendência de estabilização, particularmente no que diz respeito aos volumes de copa. Tomando por base a reduzida longevidade apresentada pelos pomares citricos localizados em regiões tropicais, em comparação com o que se verifica em climas temperados, tem-se que o periodo relacionado aos anos incluidos na anälise de vigor compreendeu a maior parte da vida ütil das plantas, cuja duração, no Reconcavo Baiano, está em torno de vinte anos.

Os resultados da anälise da variância em blocos casualizados com parcelas subdivididas no tempo, relati vos aos dados de circunferência da copa, altura da planta e diâmetro do tronco, tomados em cinco anos do periodo 1965- 1980, são apresentados na Tabela 7. Para todos os parâmetros de vigor se constata um alto nivel de significancia no que tange aos efeitos de porta-enxertos e $\bar{a}$ interaça porta-enxertos $x$ anos, refletindo diferencas concernentes ao vigor e às taxas de crescimento determinadas às copas de laran ja 'Natal' pelos diversos porta-enxertos, respectivamente. O 


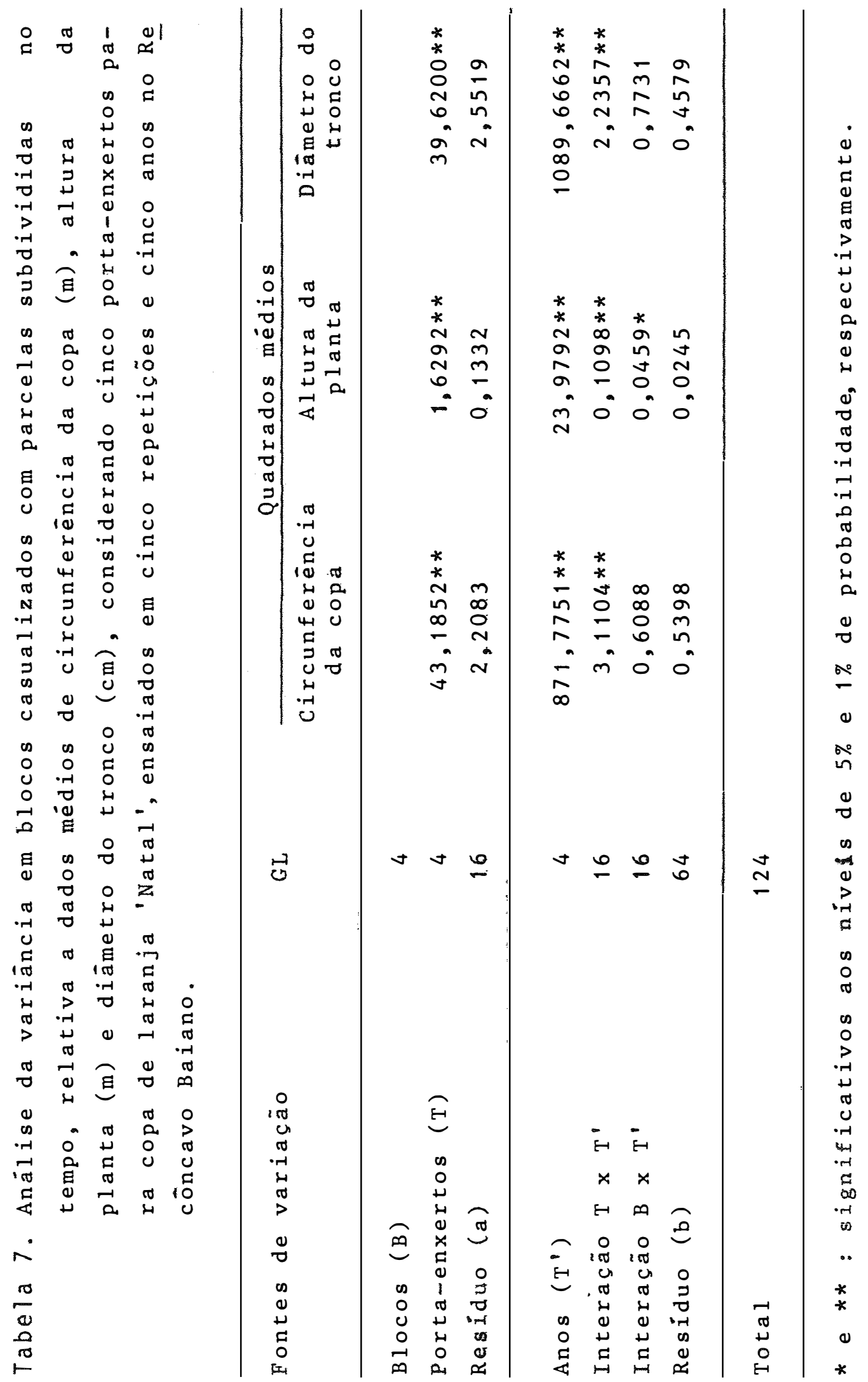


efeito de anos foi, igualmente, altamente significativo para a totalidade das caracteristicas de vigor, tendo como causa principal o desenvolvimento das plantas no decorrer do tempo, especialmente no periodo 1965-1975. A ocorrēncia de interaça o blocos $x$ anos foi significativa somente para a altura da planta, sendo devida a alteraçós no posicionamento dos blocos, quanto à grandeza da altura média de suas plantas, ao longo dos anos.

Visando melhor caracterizar o comportamento dos porta-enxertos, quanto às suas influéncias sobre o vigor das copas de laranja 'Natal', foi efetuada a análise da esta bilidade fenotipica, segundo modelo estabelecido por EBERHART e RUSSEL (1966), estando seus resultados reunidos na Tabela 8. Verifica-se que praticamente toda a variância de anos dentro de porta-enxertos é explicada pela regressão linear, devido a não significância dos desvios da regressão reunidos referentes aostrês paràmetros de vigor considerados, - que é confirmado pelos elevados valores dos coeficientes de determinação dos efeitos 1 ineares $\left(R^{2}\right)$, os quais foram da ordem de $99,64 \%, 99,41 \%$ e $99,76 \%$, calculados para os caracte res circunferéncia da copa, altura da planta e diâmetro do tronco, respectivamente (Tabela 9). A referida anälise mostra também que os genótipos foram dessemelhantes em seus com portamentos lineares, em decorréncia dos valores altamente significativos obtidos para o teste F relativo a anos (1inear) $x$ porta-enxertos. Isto indica, a exemplo do que foi constatado a partir da anälise da variancia de blocos casualizados com parcelas subdivididas no tempo, que os "cavalos" determinaram diferentes taxas de crescimento às combinaçós com laranja'Natal', ou seja, apresentaram coeficientes de regressão linear distintos.

A decomposição da variancia de anos dentro de porta-enxertos nos efeitos linear e não linear particulares 


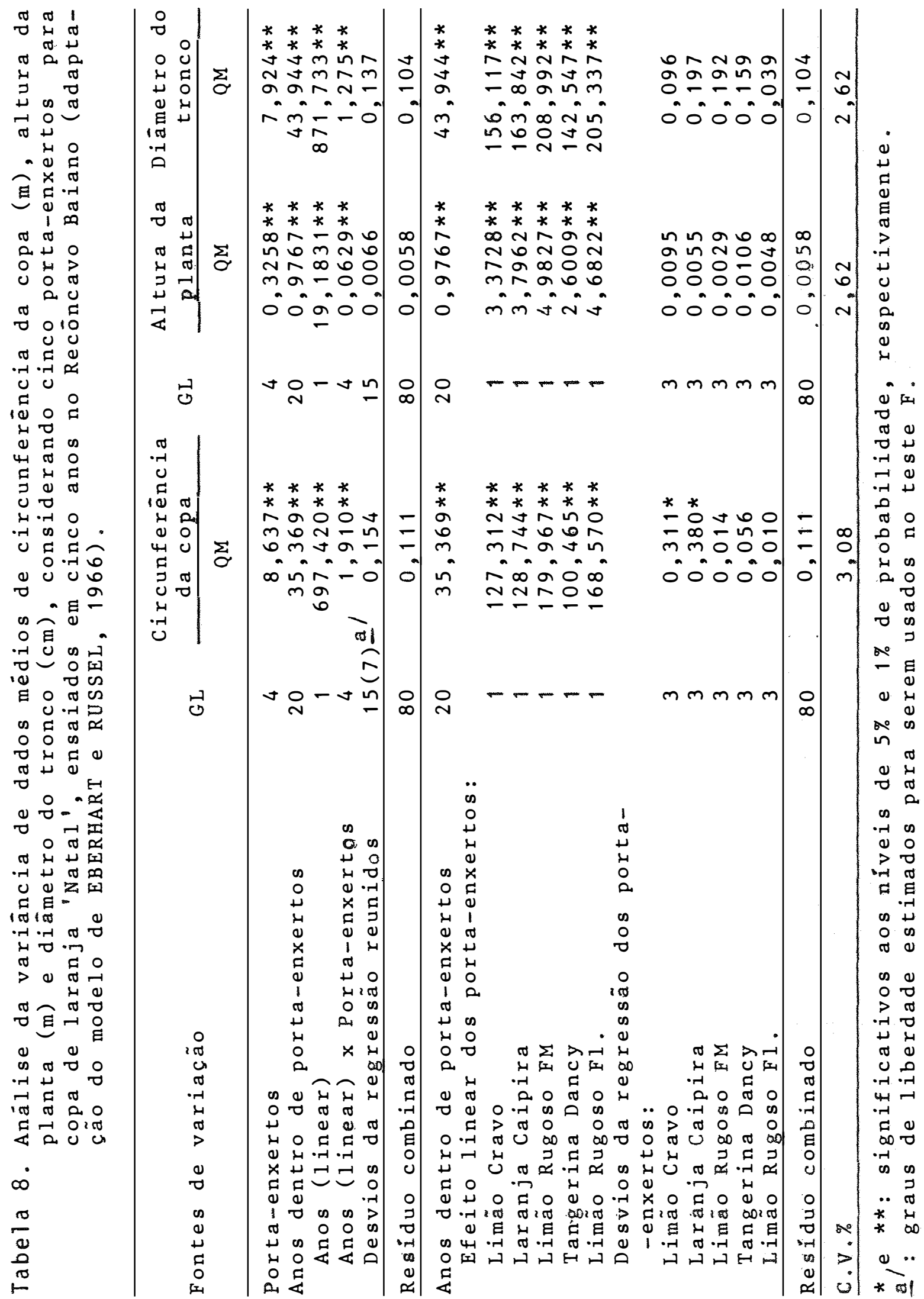




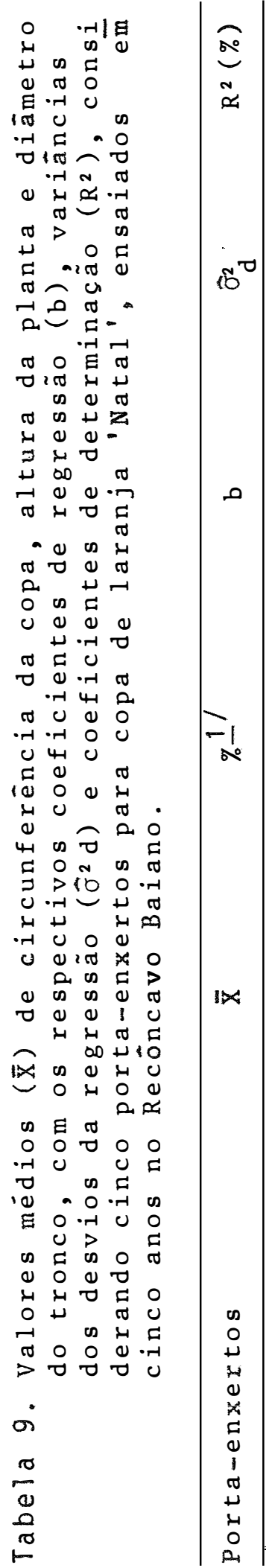

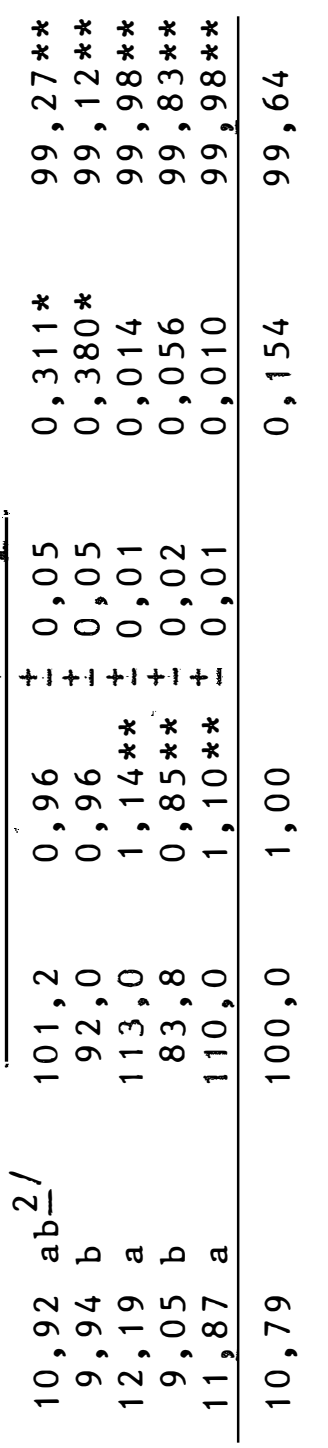
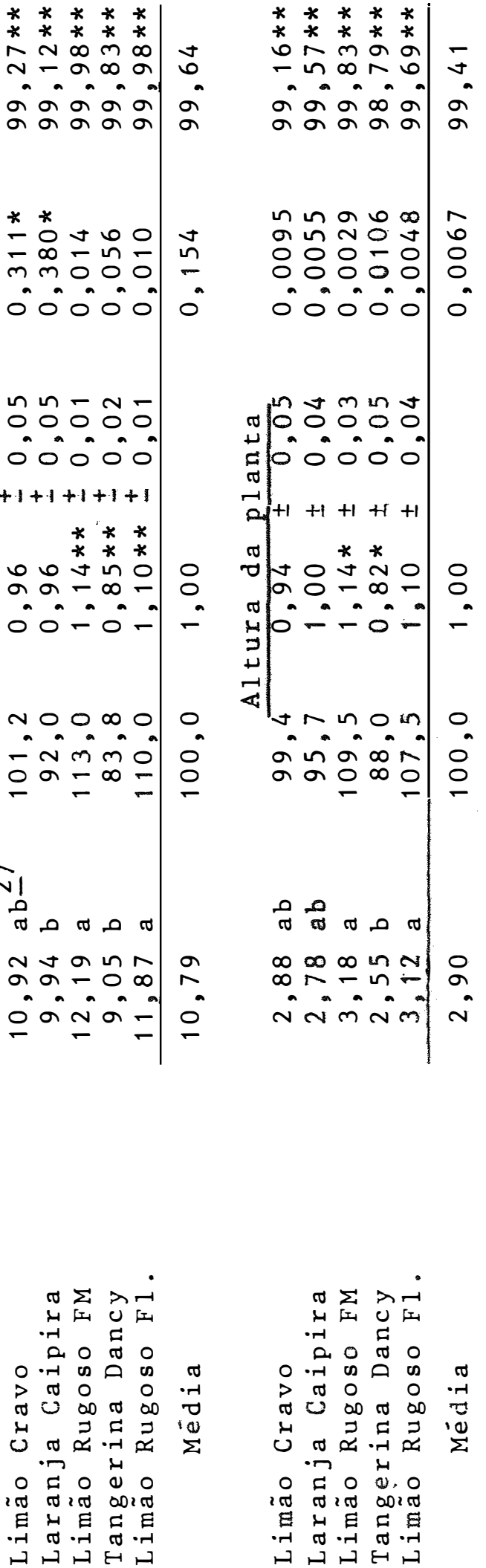

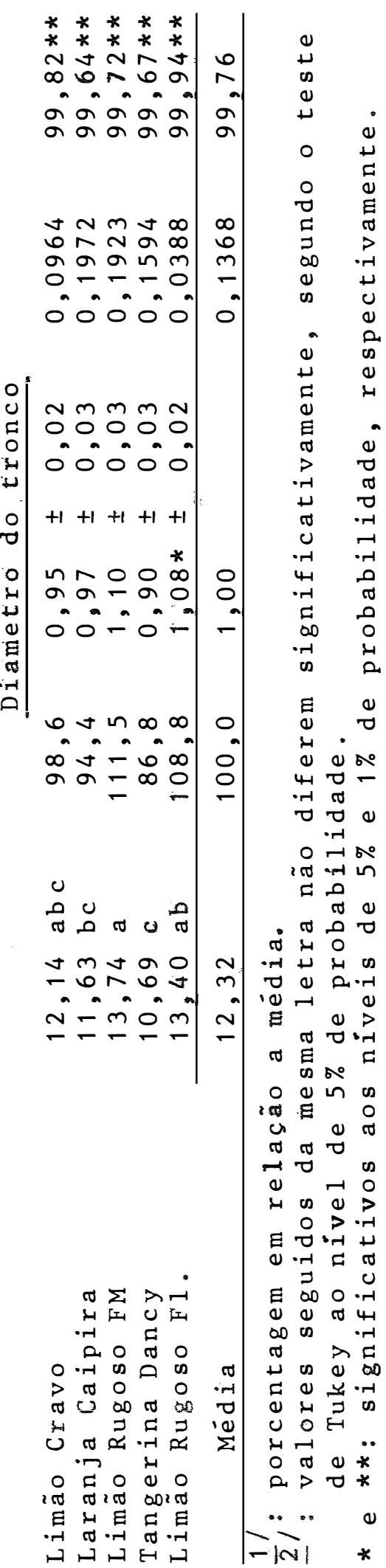


a cada porta-enxerto (segunda parte da Tabela 8), permitiu dis tinguir suas influências individuais sobre o desenvolvimento das copas. Os cinco "cavalos" expressaram respostas altamente significativas para o efeito linear, com respeito à todas as características de vigor, sendo que os coeficientes de de terminação $\left(R^{2}\right)$ calculados para cada genótipo foram, em geral, superiores a 99\% (Tabela9). A maioria das variâncias dos des vios da regressão foi estatisticamente não significativa, ten do sido verificadas, porém, exceções relativas ao 1 imão 'Cra vo' e à laranja 'Caipira'. Estes apresentaram desvios significativos da linearidade para o parâmetro circunferência da copa, denotando uma menor previsibilidade do comportamento desses porta-enxertos com respeito, somente, à essa variável.

Os coeficientes de regressão linear, conforme já citado, caracterizam a influência dos diferentes "cavalos" sobre a taxa de crescimento das copas que estão sustentando. Pela Tabela 9 constata-se que, em termos numéricos, - 1 imão 'Rugoso FM' relaciona-se aos coeficientes de regressão mais elevados, dando-se o conträrio para a tangerina 'Dancy', sendo que tais coeficientes, considerando os parámetros circunferência da copa e altura da planta, mostram-se significativamente superiores e inferiores a 1,00, segundo teste $t$, respectivamente para o limão e tangerina mencionados. Tem -se, desse modo, que o 1 imão 'Rugoso $F M$ ' foi o porta-enxerto que determinou as taxas de crescimento mais elevadas em rela ção às copas, particularmente quanto aos seus volumes, enquanto que ä tangerina 'Dancy' couberam as taxas de crescimento mais baixas. As médias obtidas para as variáveis de vigor reforçam os comentärios ora realizados.

Os Iimões 'Rugoso da Flörida' e 'Rugoso FM', bem como a tangerina 'Dancy', podem, combase no conjunto de genótipos analisados, ser distinguidos como "cavalos" de com portamento previsivel, no tocante ao desenvolvimento das co- 
pas de laranja 'Natal' sobre eles enxertadas, enquanto que o mesmo não se verifica com respeito ao limão 'Cravo' e à $1 a-$ ranja 'Caipira', em virtude dos desvios significativos da 1 i nearidade apresentados por estes porta-enxertos relativamente à circunferéncia da copa, conforme já referido. Em sinte se, quanto às taxas de desenvolvimento determinadas em rela ção às copas, valores (coeficientes b) mais acentuados foram obtidos para os limões 'Rugoso FM' e 'Rugoso da Flórida', f $\underline{i}$ cando a tangerina 'Dancy' com os mais baixos e o limão 'Cravo' e laranja 'Caipira' com os valores intermediários. Os resultados que levaram à essas consideraçós encontram-se agrupados na Tabela 9 e são ilustrados nas Figuras 3 a 8 . Pesquisas realizadas por COOK et a $i$ i (1952), SALIBE (1978), CUNHA Sobrinho et a $i$ i (1978 e 1980) e SOARES Filho et a $i$ i (1980), comprovam o vigor superior manifestado por copas citricas em combinações com o limão 'Rugoso da Flórida', contrariando, porém, resultados obtidos por MOREIRA et a $i$ i (1960) e TÉ́FILO Sobrinho et alii (1973).

\subsection{Qualidade dos frutos}

A semelhança do que foi efetuado no sub-item anterior, os resultados e a discussão das avaliaçós da quali dade dos frutos serão considerados em conjunto. Os valores médios dos dados ora examinados, comos respectivos indices anuais, são apresentados na Tabela A.3 (päg.106).

As referidas avaliações relacionaram-se a um periodo no qual o pomar se encontrava em idade adulta, estan do as caracteristicas de seus frutos bem definidas. Desse modo, as variaçós constatadas entre os diferentes anos envolvidos na análise são, principalmente, de natureza ambiental, e por isso refletem a manifestação de condiçóes ecológ cas mais ou menos favoräveis à qualidade da laranja, a depen 

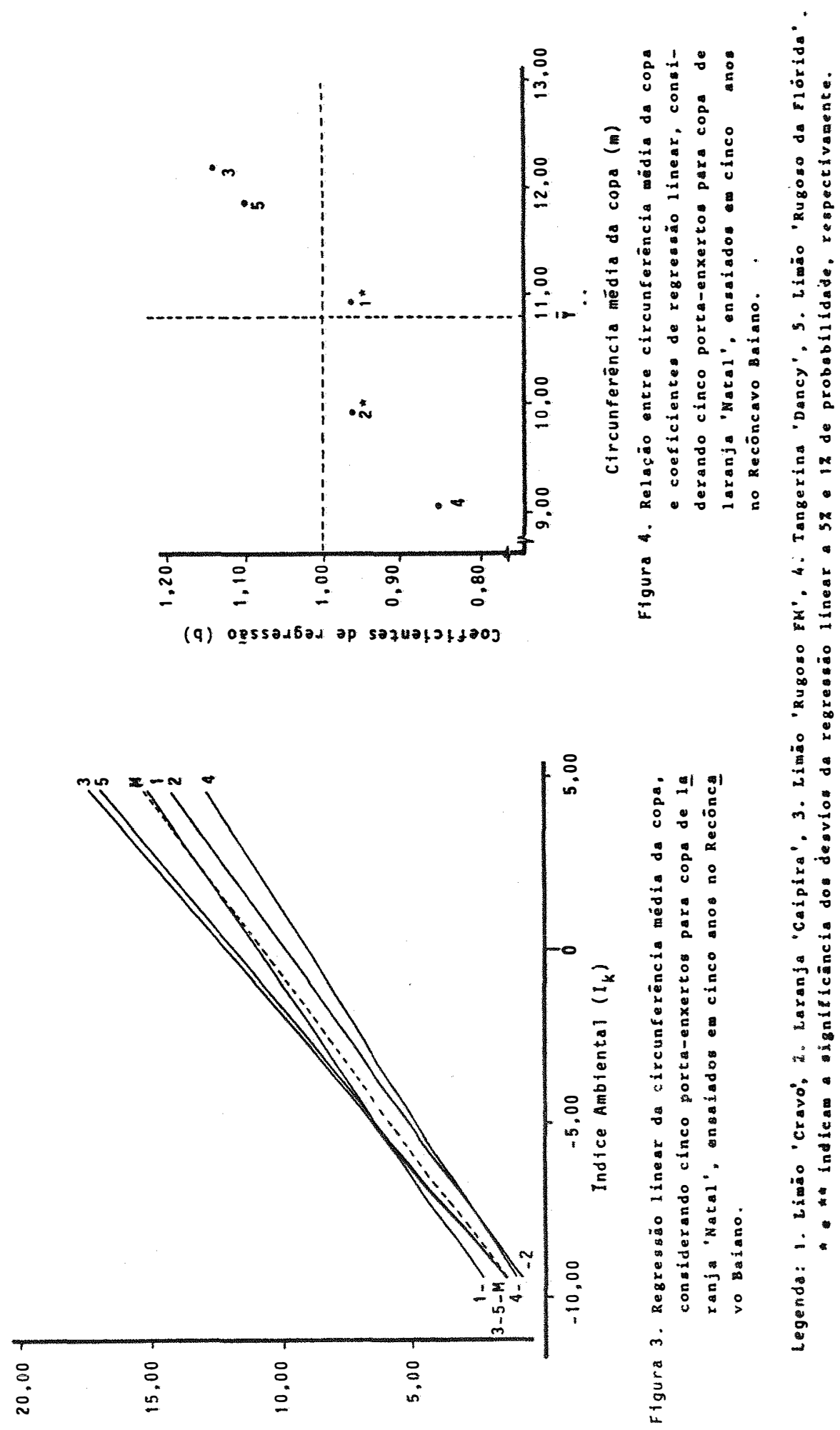

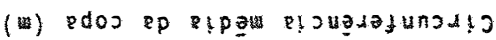


.60 .

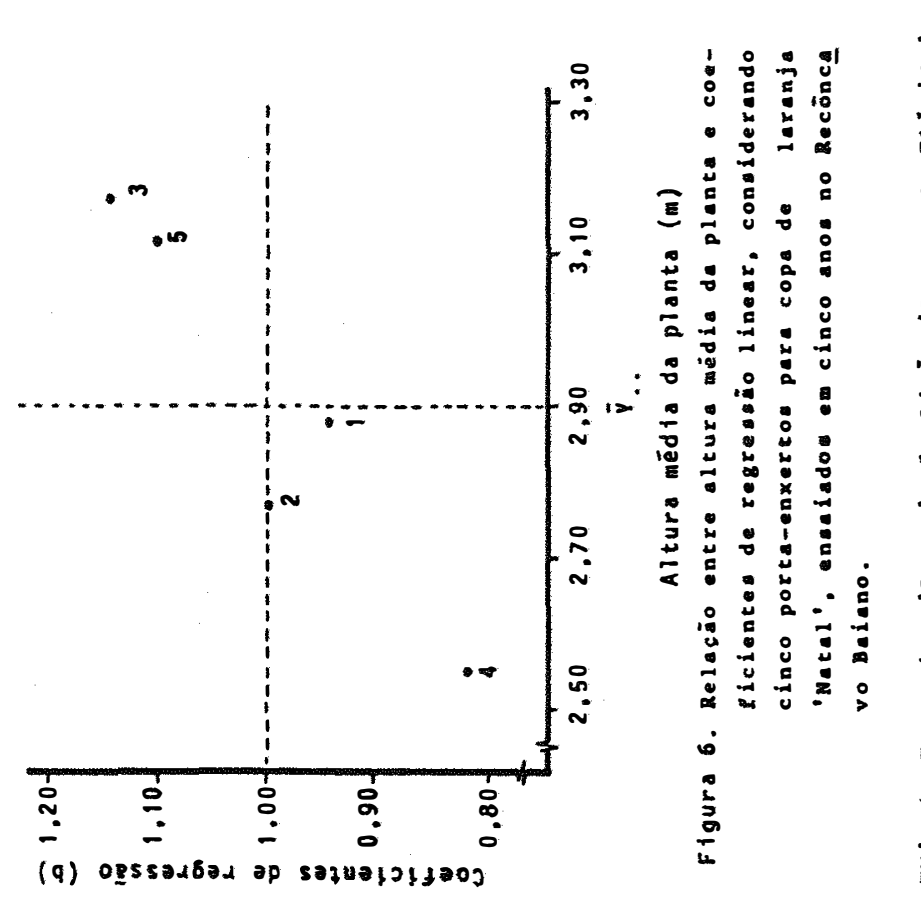

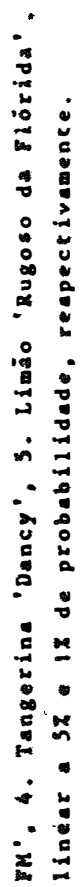

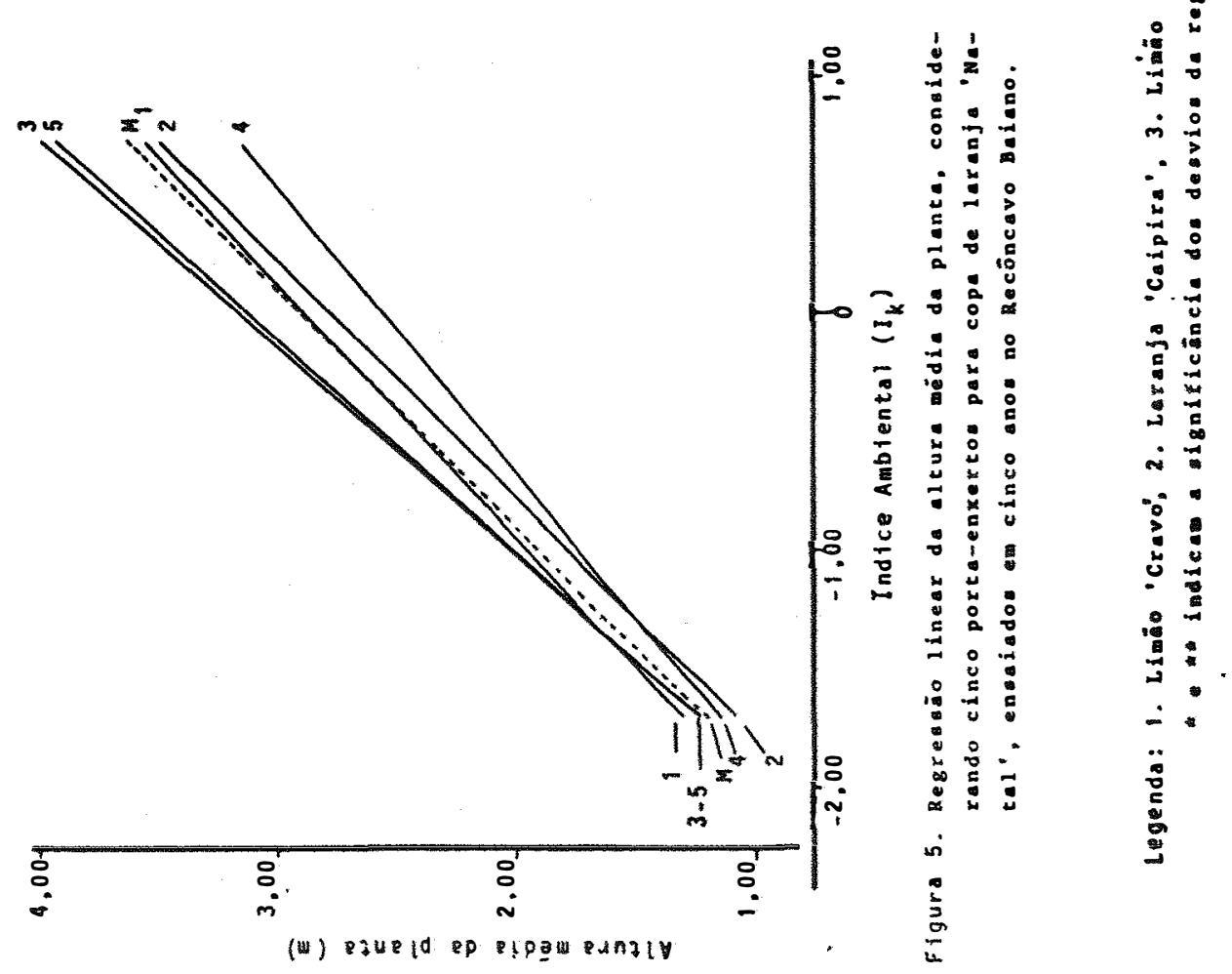


.61.

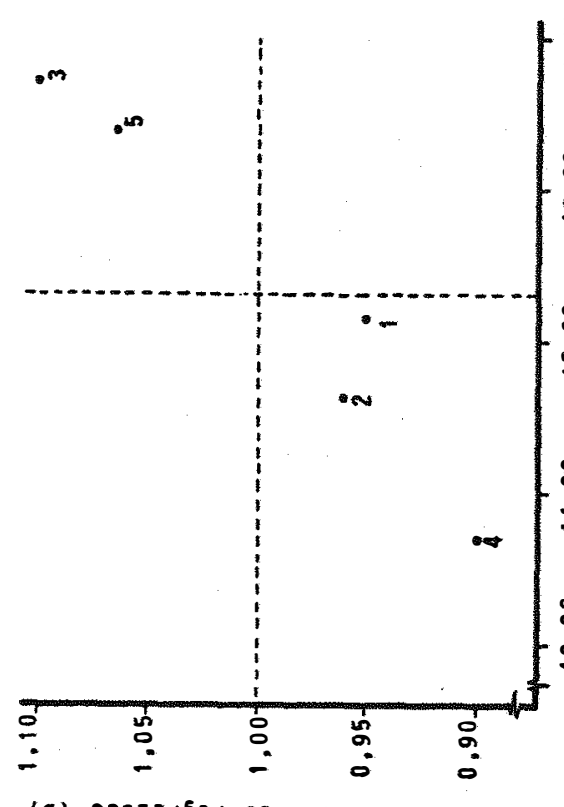

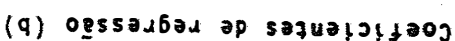
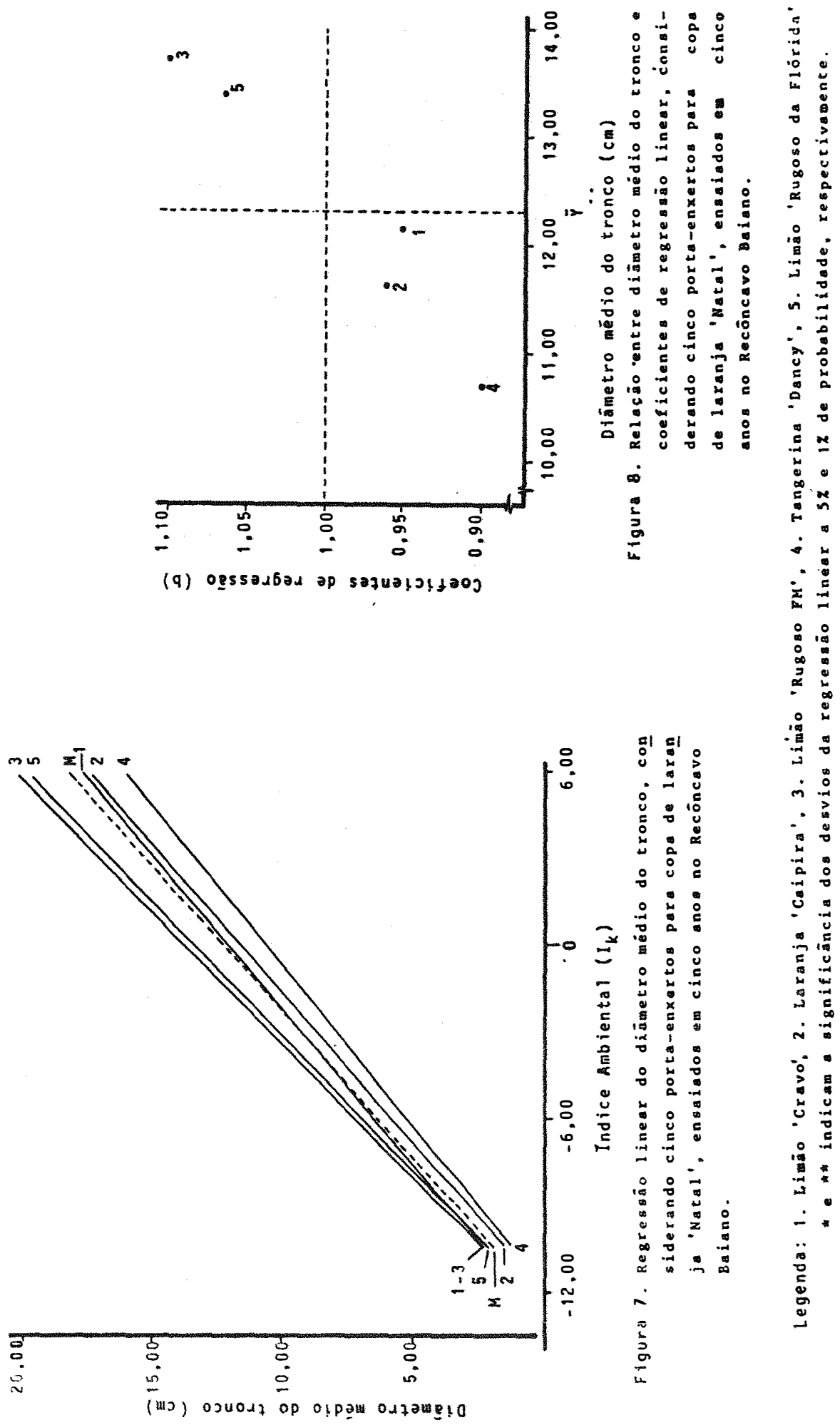
der da maior ou menor magnitude dos indices anuais, respecti vamente. Dentro desse contexto constitui exceção o caráter espessura da casca, dado que as frutas de melhor aceitação pelo mercado consumidor distinguem-se por suas cascas mais finas. Pela Tabela A.3 (pág. 106) conclui-se que o ano de 1976, em termos globais, destacou-se como aquele cujas condi ções ecológicas foram, dentro do intervalo estudado, mais fa voräveis ao desenvolvimento de frutos de melhor qualidade, ou seja, maiores e mais pesados, mais ricos em acidez e açucares, com elevada relação acidez/sólidos solüveis (A/SS) e alta porcentagem de suco, sendo esta inferior, somente, àque la estabelecida em 1980. O ano de 1980, muito embora tenha determinado a produção de frutos com cascas menos espêssas, o que configura um carāter desejável, causou, em contrapartida, reduções nos pesos e tamanhos dos mesmos, além de ter influenciado negativamente a produção de laranjas (Tabela A.1, pág. 104). Tal comportamento provavelmente se relaciona a decréscimos na atividade fisiológica das plantas, como parte de um ciclo de alternância de produções. Em continuação ao raciocínio aqui desenvolvido, o ano de 1978 desfavoreceu as porcentagens de suco e acidez total, bem como o teor de sólidos solúveis, enquanto que a relação A/ss foi prejudicada em 1977.

Os resultados da anälise da variância em blocos casualizados com parcelas subdivididas no tempo, relativos aos dados de peso, altura, diâmetro, espessura da casca, porcentagens de suco e de acidez total, teor de sólidos solú veis e relação acidez/sólidos solúveis dos frutos, obtidos durante o periodo 1976-1980, encontram-se agrupados na Tabe1a 10. Os efeitos de porta-enxertos mostraram-se significativos para a maioria dos caracteres de frutos considerados, exceção feita àqueles referentes às porcentagens de suco e de acidez total, assim como à relação A/SS, indicando que as influencias dos porta-enxertos sobre a qualidade da laranja 'Natal' foram inexpressivas, em termos estatisticos, somente 


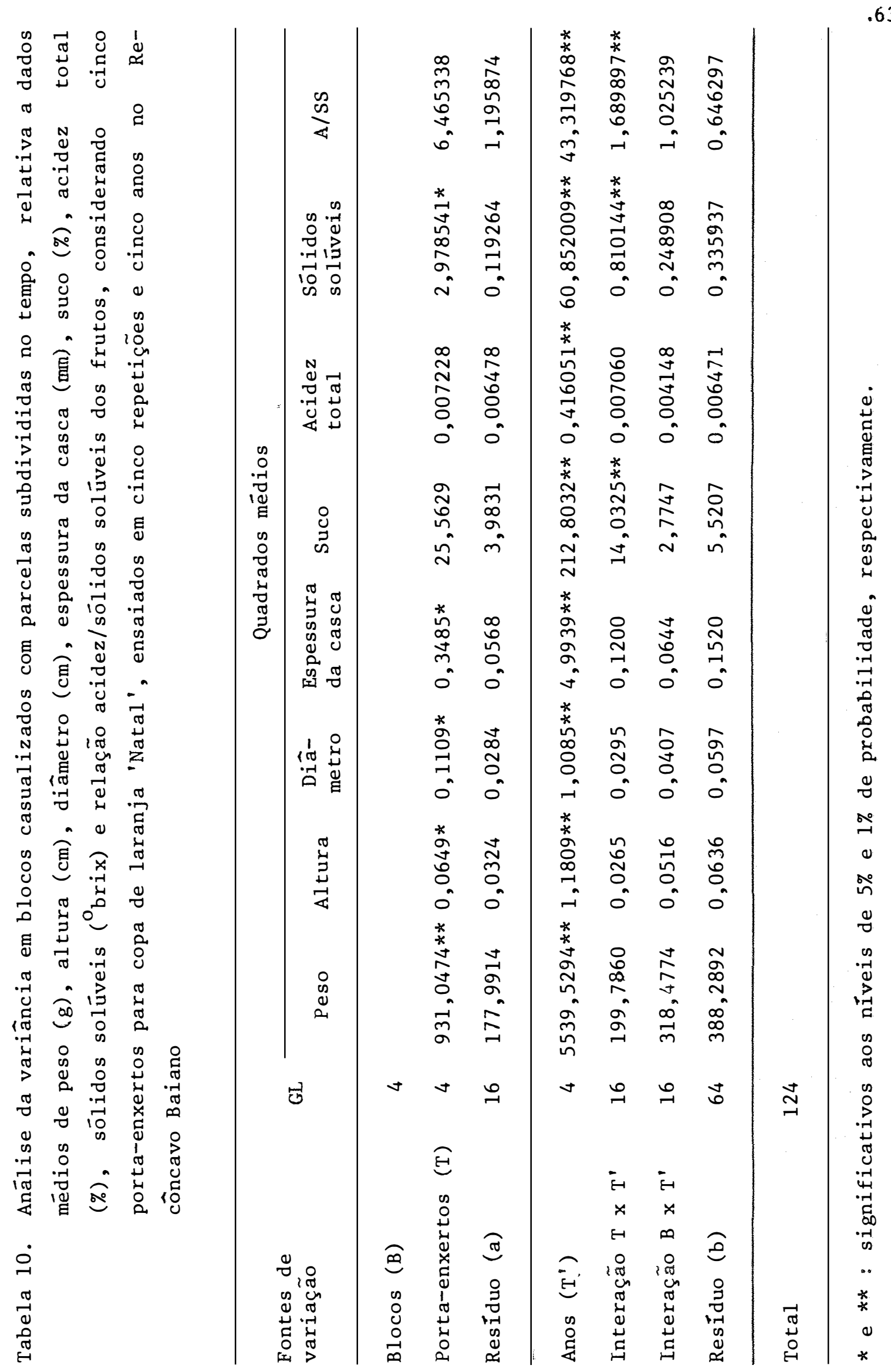


para as trēs variàveis mencionadas. O efeito de anos, por sua vez, apresentou alto nivel de significancia para a totalidade das caracteristicas ora analisadas, refletindo a exis tència de diferenças ambientais entre os anos compreendidos no estudo. Quanto à interação porta-enxertos x anos, esta foi altamente significativa apenas para os dados de porcenta gem de suco, teor de sólidos solüveis e relação acidez/sólidos solúveis dos frutos, evidenciando que, no tocante aos re feridos caracteres, os genótipos avaliados manifestaram dife renças concernentes às suas respostas às variações anuais. A interaçãoblocos $x$ anos, estatisticamente, não se fez presen te na análise como um todo, significando que o comportamento dos blocos manteve-se constante ao longo dos anos.

A qualidade da fruta citrica é resultado da combinação de uma série de fatores, não podendo ser definida, portanto, pelo exame isolado de determinados caracteres de frutos. Assim sendo, o detalhamento dos porta-enxertos incluidos nesta pesquisa, efetuado através da análise da estabilidade fenotípica, envolveu todas as variáveis consideradas de interesse, mesmo aquelas que não se relacionaram a in terações porta-enxertos $x$ anos significativas, conforme demonstrado pela anälise da variāncia em blocos casualizados com parcelas subdivididas no tempo (Tabela 10). Os resultados da análise da estabilidade, relativos à qualidade dos frutos, encontram-se reunidos na Tabela 11, onde se constata que os efeitos de porta-enxertos, em geral, são semelhantes àqueles distinguidos pela anälise da variancia em blocos casualizados com parcelas subdivididas no tempo. Esta ültima, porém, ao contrário da primeira, não identifica, conforme foi citado, efeito de porta-enxertos para a porcentagem de suco, indicando, provavelmente, sua menor sensibilidade em comparação com a anảlise da estabilidade.

A variância de anos dentro de porta-enxertos, 


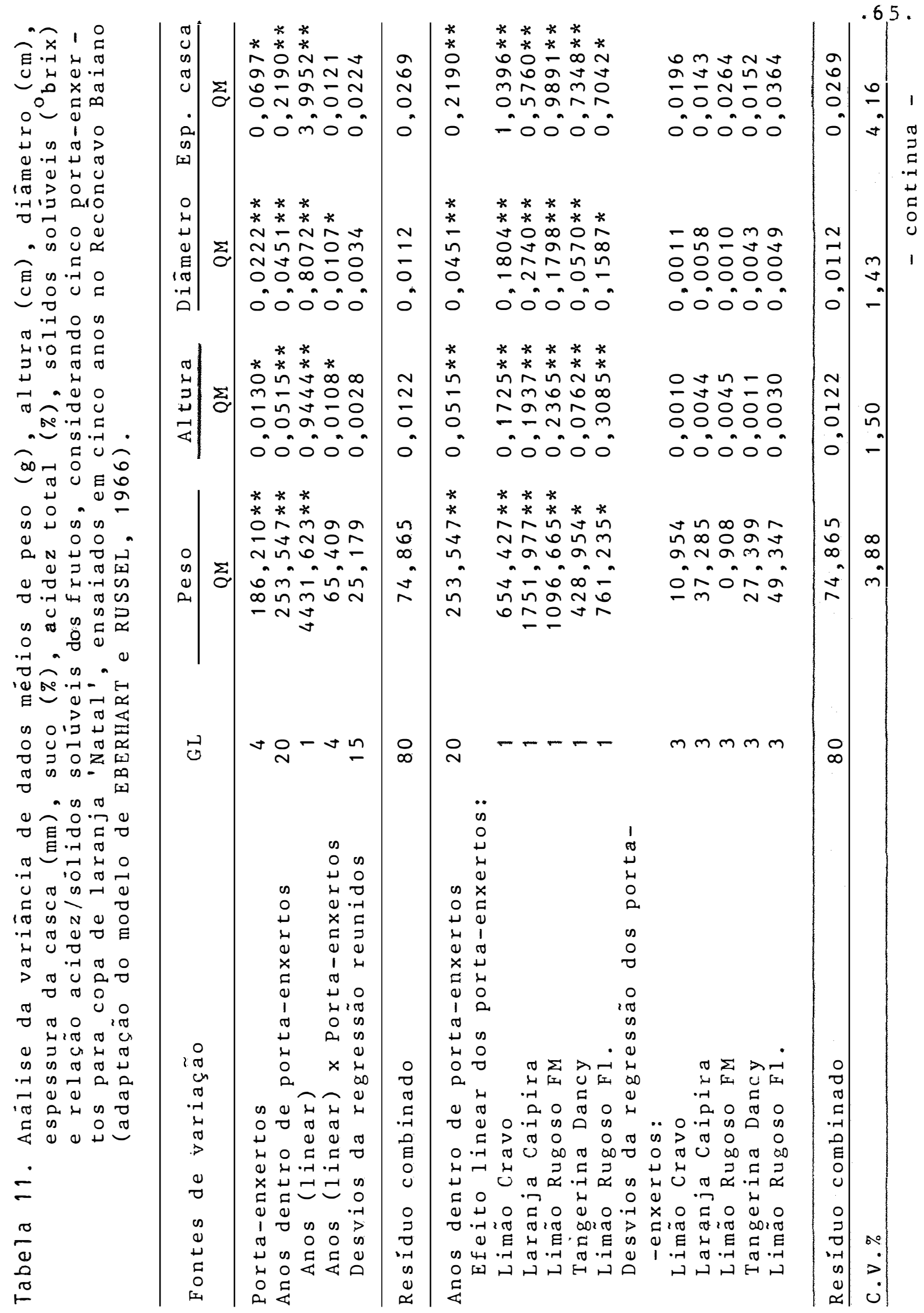


.66.

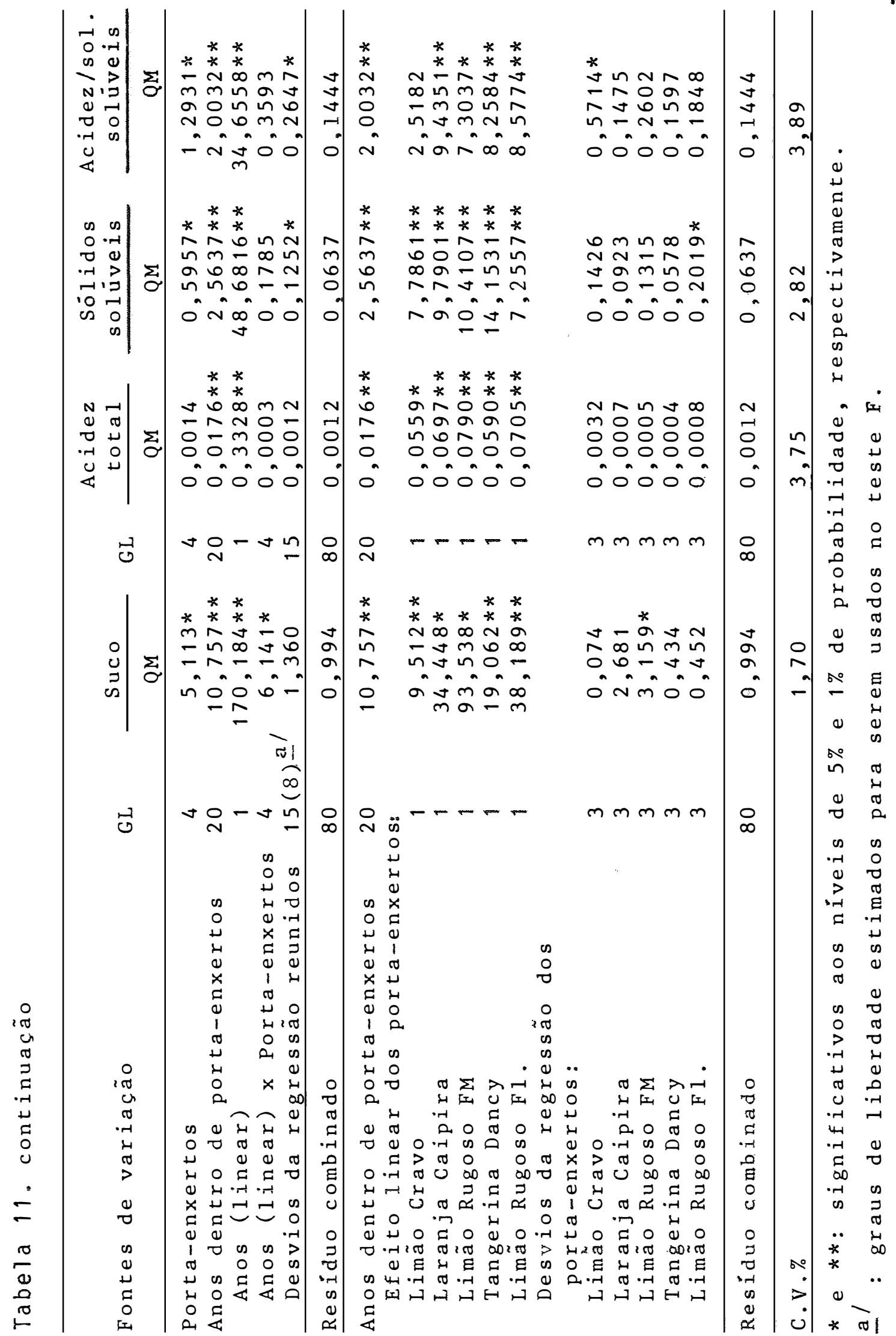


para a totalidade das características dos frutos, foi bem de finida pela regressão linear, verificando-se que os desvios da regressão reunidos mostraram-se significativos somente quanto ao teor de açúcares e relação A/SS. Esses resultados são corroborados pelos elevados coeficientes de determinação $\left(R^{2}\right)$ obtidos para os distintos caracteres analisados, os quais, em sua maioria, foram superiores a $91 \%$, sendo exceção o coeficiente de determinação constatado para a relação A/SS, cujo valor foi de $86,76 \%$ (Tabela 12). A interação porta-enxertos $x$ anos ( 1 inear), por sua vez, apresentou níveis significantes para a altura, diâmetro e porcentagem de suco, - mesmo não se dando para as demais características dos frutos, estabelecendo que as respostas dos genótipos às variações anuais, refletidas por seus coeficientes de regressão linear, diferiram entre si com respeito apenas às três variáveis mencionadas. Esses resultados sugerem, a exemplo do que foi constatado por SANTos (1980), em relação aos componentes primärios da produção de feijão (número de vagens por planta, nümero de sementes por vagem e peso de 100 sementes), que as variações ambientais (anuais) afetaram de maneira independente os coeficientes de regressão linear associados aos diferentes caracteres de frutos.

O exame da segunda parte da Tabela 11 possib lita discriminar a influência de cada porta-enxerto sobre a qualidade da laranja 'Natal'. Os "cavalos" apresentaram res postas altamente significativas para o efeito linear, no que se refere à maioria das variáveis de frutos. Efeito linear não significativo foi obtido, unicamente, para a relação acidez/ sólidos solúveis dos frutos produzidos por copas tendo como porta-enxerto o 1 imão 'Cravo'. Esses resultados foram confirmados pelos coeficientes de determinação dos efeitos 1 ineares $\left(R^{2}\right)$, cujos níveis de significância se igualaram, em sua quase totalidade, aos dos efeitos lineares relativos a cada genótipo (Tabela 12). Quanto às variâncias dos desvios da regressão, efeitos significativos foram evidenciados para 
.68 .

Tabela 12. Valores médios $(\bar{x})$ de peso, altura, diâmetro, espessura da casca, suco, acidez total, sölidos so1 üveis e relação acidez/sölidos solüveis dos frutos, com os respectivos coeficientes de regressão (b), variâncias dos desvios da regressão ( $\widehat{\sigma}_{\mathrm{d}}^{2}$ ) e coeficientes de determinação $\left(R^{2}\right)$, considerando cinco porta-enxertos para copa de laranja 'Natal', ensaiados em cinco anos no Recóncavo Baiano.

\begin{tabular}{|c|c|c|c|c|c|c|}
\hline Porta-enxertos & $\overline{\mathrm{x}}$ & $\% 1 /$ & & $\mathrm{b}$ & $\hat{\sigma}_{\mathrm{d}}^{\hat{2}}$ & $\mathrm{R}^{2}(\%)$ \\
\hline & \multicolumn{6}{|c|}{ Peso médio dos frutos } \\
\hline $\begin{array}{l}\text { Limão Cravo } \\
\text { Laranja Caipira } \\
\text { Limão Rugoso FM } \\
\text { Tange rina Dancy } \\
\text { Limão Rugo so F1. }\end{array}$ & $\begin{array}{l}219,15 a-27 \\
232,93 a \\
224,78 a \\
217,84 a \\
220,60 a\end{array}$ & $\begin{array}{r}98,2 \\
104,4 \\
100,8 \\
97,7 \\
98,9 \\
\end{array}$ & $\begin{array}{l}0,86 \\
1,41 \\
1,11 * \\
0,70 \\
0,93 \\
\end{array}$ & $\begin{array}{l} \pm 0,11 \\
\pm 0,20 \\
\pm 0,03 \\
\pm 0,18 \\
\pm 0,24 \\
\pm\end{array}$ & $\begin{array}{r}10,954 \\
37,285 \\
0,908 \\
27,399 \\
49,347 \\
\end{array}$ & $\begin{array}{l}95,22 * * \\
94,00 * * \\
99,75 * * \\
83,92 * \\
83,72 * \\
\end{array}$ \\
\hline Média & \multicolumn{6}{|c|}{ Altura média dos frutos } \\
\hline $\begin{array}{l}\text { Limão Cravo } \\
\text { Laranja Caipira } \\
\text { Limão Rugoso FM } \\
\text { Tangerina Dancy } \\
\text { Limão Rugoso F1. }\end{array}$ & $\begin{array}{l}7,36 a \\
7,45 a \\
7,39 a \\
7,32 a \\
7,34 a \\
\end{array}$ & $\begin{array}{r}99,9 \\
101,1 \\
100,3 \\
99,3 \\
99,6 \\
\end{array}$ & $\begin{array}{l}0,96 \\
1,01 \\
1,12 \\
0,64 * \\
1,28 \\
\end{array}$ & $\begin{array}{l} \pm 0,07 \\
\pm 0,15 \\
\pm 0,15 \\
\pm 0,08 \\
\pm 0,13\end{array}$ & $\begin{array}{l}0,0010 \\
0,0044 \\
0,0045 \\
0,0011 \\
0,0030\end{array}$ & $\begin{array}{l}98,33 * * \\
93,58 * * \\
94,63 * * \\
96,00 * * \\
97,08 * *\end{array}$ \\
\hline Média & \multicolumn{6}{|c|}{ Diämetro médio dos frutos } \\
\hline $\begin{array}{l}\text { Limão Cravo } \\
\text { Laranja Caipira } \\
\text { Limão Rugoso FM } \\
\text { Tangerina Dancy } \\
\text { Limão Rugoso F1. }\end{array}$ & $\begin{array}{l}7,35 a \\
7,48 a \\
7,44 a \\
7,32 a \\
7,39 a \\
\end{array}$ & $\begin{array}{r}99,3 \\
101,1 \\
100,5 \\
98,9 \\
99,9 \\
\end{array}$ & $\begin{array}{l}1,06 \\
1,30 \\
1,06 \\
0,60 \\
0,99 \\
\end{array}$ & $\begin{array}{l} \pm 0,08 \\
\pm 0,19 \\
\pm 0,08 \\
\pm 0,16 \\
\pm 0,17 \\
\pm\end{array}$ & $\begin{array}{l}0,0011 \\
0,0058 \\
0,0010 \\
0,0043 \\
0,0049 \\
\end{array}$ & $\begin{array}{l}98,11 * * \\
94,06 * * \\
98,53 * * \\
81,74 * \\
91,47 * \\
\end{array}$ \\
\hline Média & \multicolumn{5}{|c|}{ Espessura média da casca dos frutos } & $\begin{array}{l}92,78 \\
s\end{array}$ \\
\hline $\begin{array}{l}\text { Limão Cravo } \\
\text { Laranja Caipira } \\
\text { Limão Rugoso FM } \\
\text { Tangerina Dancy } \\
\text { Limão Rugoso F1. }\end{array}$ & $\begin{array}{l}3,86 a \\
4,03 a \\
4,08 a \\
3,80 a \\
3,93 a\end{array}$ & $\begin{array}{r}98,0 \\
102,3 \\
103,6 \\
96,4 \\
99,8\end{array}$ & $\begin{array}{l}1,14 \\
0,85 \\
1,11 \\
0,96 \\
0,94\end{array}$ & $\begin{array}{l} \pm 0,16 \\
\pm 0,13 \\
\pm 0,18 \\
\pm 0,14 \\
\pm 0,21\end{array}$ & $\begin{array}{l}0,0196 \\
0,0143 \\
0,0264 \\
0,0152 \\
0,0364\end{array}$ & $\begin{array}{l}94,65 * * \\
93,07 * * \\
92,59 * * \\
94,16 * * \\
86,58 *\end{array}$ \\
\hline Média & 3,94 & 100,0 & 1,00 & & 0,0224 & 92,21 \\
\hline
\end{tabular}


Tabela 12. continuação

\begin{tabular}{|c|c|c|c|c|c|c|}
\hline Porta-enxertos & $\overline{\mathrm{x}}$ & $\%$ & & $\mathrm{~b}$ & $\tilde{\sigma}^{2} \mathrm{~d}$ & $\mathrm{R}^{2}(\%)$ \\
\hline & \multicolumn{6}{|c|}{ Porcentagem média de suco dos frutos } \\
\hline $\begin{array}{l}\text { Limão Cravo } \\
\text { Laranja Caipira } \\
\text { Limão Rugoso FM } \\
\text { Tangerina Dancy } \\
\text { Limão Rugoso F1. }\end{array}$ & $\begin{array}{l}58,66 a \\
59,02 a \\
57,27 a \\
59,83 a \\
57,79 a\end{array}$ & $\begin{array}{r}100,3 \\
100,9 \\
97,9 \\
102,3 \\
98,8 \\
\end{array}$ & $\begin{array}{l}0,53 * * \\
1,01 \\
1,66 \\
0,75 \\
1,06\end{array}$ & $\begin{array}{l} \pm 0,05 \\
\pm 0,28 \\
\pm 0,30 \\
\pm 0,11 \\
\pm 0,12\end{array}$ & $\begin{array}{l}0,074 \\
2,681 \\
3,159 * \\
0,434 \\
0,452\end{array}$ & $\begin{array}{l}97,72 * * \\
81,07 * \\
90,80 * \\
93,61 * * \\
96,57 * * \\
\end{array}$ \\
\hline \multirow[t]{2}{*}{ Média } & 58,51 & 100,0 & 1,00 & & 1,360 & 91,95 \\
\hline & \multicolumn{3}{|c|}{ Porcentagem média de } & acidez & total dos & frutos \\
\hline $\begin{array}{l}\text { Limão Cravo } \\
\text { Laranja Caipira } \\
\text { Limão Rugoso FM } \\
\text { Tangerina Dancy } \\
\text { Limão Rugoso F1. }\end{array}$ & $\begin{array}{l}0,907 a \\
0,908 a \\
0,946 a \\
0,935 a \\
0,927 a \\
\end{array}$ & $\begin{array}{r}98,0 \\
98,2 \\
102,3 \\
101,1 \\
100,2 \\
\end{array}$ & $\begin{array}{l}0,92 \\
1,02 \\
1,09 \\
0,94 \\
1,03 \\
\end{array}$ & $\begin{array}{l} \pm 0,22 \\
\pm 0,10 \\
\pm 0,09 \\
\pm 0,08 \\
\pm 0,11 \\
\pm\end{array}$ & $\begin{array}{l}0,0032 \\
0,0007 \\
0,0005 \\
0,0004 \\
0,0008 \\
\end{array}$ & $\begin{array}{l}85,19 * \\
96,96 * * \\
98,00 * * \\
97,79 * * \\
96,58 * * \\
\end{array}$ \\
\hline \multirow[t]{2}{*}{ Média } & 0,925 & 100,0 & 1,00 & & 0,0011 & 94,90 \\
\hline & \multicolumn{6}{|c|}{ Teor médio de sólidos solúveis dos frutos } \\
\hline $\begin{array}{l}\text { Limão Cravo } \\
\text { Laranja Caipira } \\
\text { Limão Rugoso FM } \\
\text { Tangerina Dancy } \\
\text { Limão Rugoso F1. }\end{array}$ & $\begin{array}{l}9,26 a \\
9,10 a \\
8,51 a \\
9,18 a \\
8,62 a \\
\end{array}$ & $\begin{array}{r}103,7 \\
101,9 \\
95,3 \\
102,8 \\
96,5 \\
\end{array}$ & $\begin{array}{l}0,89 \\
1,00 \\
1,03 \\
1,21 \\
0,86 \\
\end{array}$ & $\begin{array}{l} \pm 0,12 \\
\pm 0,10 \\
\pm 0,12 \\
\pm 0,08 \\
\pm 0,14\end{array}$ & $\begin{array}{l}0,1426 \\
0,0923 \\
0,1315 \\
0,0578 \\
0,2019 * \\
\end{array}$ & $\begin{array}{l}94,79 * * \\
97,25 * * \\
96,35 * * \\
98,79 * * \\
92,29 * * \\
\end{array}$ \\
\hline \multirow[t]{2}{*}{ Média } & 8,93 & 100,0 & 1,00 & & 0,1252 & 95,89 \\
\hline & \multicolumn{6}{|c|}{ Relação acidez/sölidos solúveis dos frutos } \\
\hline $\begin{array}{l}\text { Limão Cravo } \\
\text { Laranja Caipira } \\
\text { Limão Rugoso FM } \\
\text { Tangerina Dancy } \\
\text { Limão Rugoso Fl. }\end{array}$ & $\begin{array}{r}10,30 a \\
10,15 a \\
9,08 a \\
9,88 a \\
9,43 a \\
\end{array}$ & $\begin{array}{r}105,4 \\
103,9 \\
92,9 \\
101,1 \\
96,5 \\
\end{array}$ & $\begin{array}{l}0,60 \\
1,17 \\
1,03 \\
1,09 \\
1,11\end{array}$ & $\begin{array}{l} \pm 0,29 \\
\pm 0,15 \\
\pm 0,19 \\
\pm 0,15 \\
\pm 0,16\end{array}$ & $\begin{array}{l}0,5714 * \\
0,1475 \\
0,2602 \\
0,1597 \\
0,1848 \\
\end{array}$ & $\begin{array}{l}59,50 \\
95,52 * * \\
90,34 * \\
94,52 * * \\
93,93 * * \\
\end{array}$ \\
\hline Média & 9,77 & 100,0 & 1,00 & & 0,2647 & 86,76 \\
\hline
\end{tabular}

1/: porcentagem em relação a média.

2/: valores seguidos da mesma letra não diferem significativamente, segundo o teste de Tukey ao nivel de $5 \%$ de probabilidade.

* e**: significativos aos niveis de $5 \%$ e $1 \%$ de probabilidade, respectivamente. 
os 1 imões 'Rugoso FM', 'Rugoso da Flörida' e 'Cravo', no tocante à porcentagem de suco, teor de sölidos solúveis e rela ção A/SS, respectivamente, expressando a imprevisibilidade do comportamento desses porta-enxertos com relação às referi das caracteristicas.

Os coeficientes de regressão, com base na sig nificância da interação porta-enxertos $x$ anos ( 1 inear), dife riram entre si com respeito somente à altura, diàmetro e por centagem de sucodosfrutos, conforme jà comentado. 0 empre go do teste $t$, por sua vez, acusou que os coeficientes de re gressão relativos à altura, porcentagem de suco e peso dos frutos, foram os ünicos que diferiram de 1,00, coincidindo tais observações, portanto, com as indicações da anàlise da estabilidade concernentes apenas aos dois primeiros caracteres de frutos. A não constatação de diferenças entre os coe ficientes de regressão associados ao diámetro dos frutos, pe 10 teste $t$, foi devida, particularmente, aos altos desvios apresentados pelos valores numericamente mais afastados de 1,00. Esse teste, por outro lado, póde estabelecer que o coeficiente de regressão do 1 imão 'Rugoso FM', referente ao peso dos frutos, foi estatisticamente superior a 1,00, em virtude do reduzido desvio a ele relacionado. Considerando os resultados obtidos com base no teste $t$, pelo fato de serem especificos a cada porta-enxerto, verifica-se que todos os coeficientes de regressão linear atinentes à laranja 'Ca pira' e ao limão 'Rugoso da Flörida' não diferiram significa tivamente de 1,00. O 1 imão 'Cravo' apresentou, relativamente à porcentagem de suco, um coeficiente de regressão inferior a 1,00 altamente significativo, definindo uma forte ten dência no sentido de manter constante a porcentagem de suco dos frutos produzidos pelas copas de laranja' 'Natal', independentemente das variações anuais. Situação semelhante, em bora menos acentuada, foi constatada para a tangerina 'Dancy', 
no que diz respeito à altura dos frutos. 0 limão 'Rugoso FM', por sua vez, manifestou uma propensão quanto à indução de desenvolvimento de laranjas mais pesadas sob condições ecologicamente mais favoráveis à essa característica de frutos, conforme se verifica por sua associação a um coeficiente de regressão significativamente superior a 1,00 (Tabela 12). Coeficientes de regressão iguais à unidade, convém salientar, indicam uma tendência relacionada à manifestação de respostas crescentes, relativas às variáveis consideradas, frente à melhoria das condições ambientais.

Em resumo, a laranja 'Caipira', segundo o critério de estabilidade proposto por EBERHART e RUSSEL (1966), destacou-se como o genótipo de melhor comportamento, dado que apresentou, para todos os caracteres de frutos analisados, desvios da linearidade estatisticamente nulos e coeficientes de regressão que, de acordo com o teste t, não diferiram da unidade, sendo que as médias fenotípicas observadas para esse porta-enxerto foram, em sua maioria, ligeiramente superiores à média geral, constituindo exceção a porcentagem de acidez total. No que se refere à espessura da casca dos frutos, cabe esclarecer: situações mais favoráveis seriam aquelas relacionadas a baixos valores para essa característica, associadas a coeficientes b inferiores a 1,00 , tendose em vista que as frutas cítricas de melhor qualidade são reconhecidas, entre outros fatores, por suas cascas mais finas, conforme jà salientado.

$$
\text { A tangerina 'Dancy' apresentou, igualmente, }
$$

comportamentos previsíveis no tocante à todas as características ora consideradas. Os frutos produzidos por combinações envolvendo esse "cavalo", entretanto, foram os de menor peso e tamanho, com tendência a não manifestarem acréscimos satisfatórios, quanto à expressão dessas variáveis, em res- 
posta à melhoria das condições ambientais, conforme se evidencia por coeficientes de regressão numericamente menores que 1,00 , sendo que o b associado à altura dos frutos teve valor significativamente inferior à unidade, segundo já comentado. No que concerne às porcentagens de suco e acidez total, quantidade de açúcares e relação A/SS, os valores observados para o porta-enxerto em questão mostraram pequena superioridade em relação à média geral.

Quanto ao limão 'Cravo', a relação acidez/sólidos solúveis dos frutos produzidos a partir de sua combina ção com a laranja 'Natal', apesar de superior à média do con junto de genótipos, não se ajustou ao modelo linear considerado no presente estudo, como conseqüēncia da não significān cia dos efeitos 1 ineares observados para essa caracteristica, a par da ocorrēncia de desvios significativos da regressão, conforme relato anterior. Seu comportamento, porém, foi pre visivel com respeito aos outros sete caracteres de frutos analisados. Aspecto de especial interesse, associado ao citado limão, refere-se à sua pouca sensibilidade às variações anuais relativamente à porcentagem de suco, cujos niveis além de atenderem às exigências de mercado, sendo em média pouco mais elevados que a média geral, tenderam a permanecer constantes ao longo dos anos, segundo demonstrado por um coeficiente de regressão significativante inferior a 1,00. Os valores de peso, tamanho e acidez total dos frutos, relaciona dos à esse "cavalo", foram ligeiramente inferiores aos das médias gerais correspondentes, dando-se o contrário para o teor de açúcares, bem como para a relação A/SS e porcentagem de suco, estes ültimos já discutidos.

Respostas não previstas pelo modelo 1 inear em pregado na anälise da estabilidade fenotipica, referentes ao teor de sólidos solúveis e à porcentagem de suco, foram obti das para os limões 'Rugoso da Flórida' e 'Rugoso FM', respec 
tivamente, conforme indicado por desvios significativos da linearidade. 0 peso, tamanho, espessura da casca e porcenta gem de acidez total dos frutos, induzidos por esses porta-en xertos, apresentaram valores médios próximos aos das respectivas médias gerais, com pequena vantagem em favor do 1 imão 'Rugoso FM'. No que tange à porcentagem de suco, teor de só lidos solúveis e à relação A/SS, os valores médios observados situaram-se abaixo das médias gerais correlatas, verificando-se agora uma leve superioridade do limão 'Rugoso da Flórida' em relação ao 'Rugoso FM'.

Os comportamentos manifestados pelos distintos porta-enxertos, concernentes às caracteristicas fisico-quimicas induzidas à laranja 'Natal', em geral não apresentaram grandes discrepāncias entre si, sendo ilustrados nas Figuras 9 a 24. A má qualidade comumente atribuida aos frutos produzidos por combinações tendo o 1 imão 'Rugoso da Flörida' como porta-enxerto (COOK et a $i$ i , 1952; MONTENEGRO et alii, 1961; MOREIRA et alii, 1960, HEARN et alii, 1974, SALIBE e MISCHAN 1978) não foi confirmada pelo presente trabalho. Apesar da porcentagem de suco, teor de açúcares e re 1 ação acidez/sólidos solúveis dos frutos terem apresentado valores inferiores em combinaçós com os 1 imões 'Rugoso da F1órida' e 'Rugoso FM', as diferenças em relação aos demais porta-enxertos foram pouco pronunciadas. As laranjas produzidas por copas sustentadas por esses limões, em contrapartida, caracterizaram-se por médias de peso, tamanho e porcenta gem de acidez total superiores às do limão 'Cravo', porta-enxerto hoje mais difundido na citricultura brasileira. 


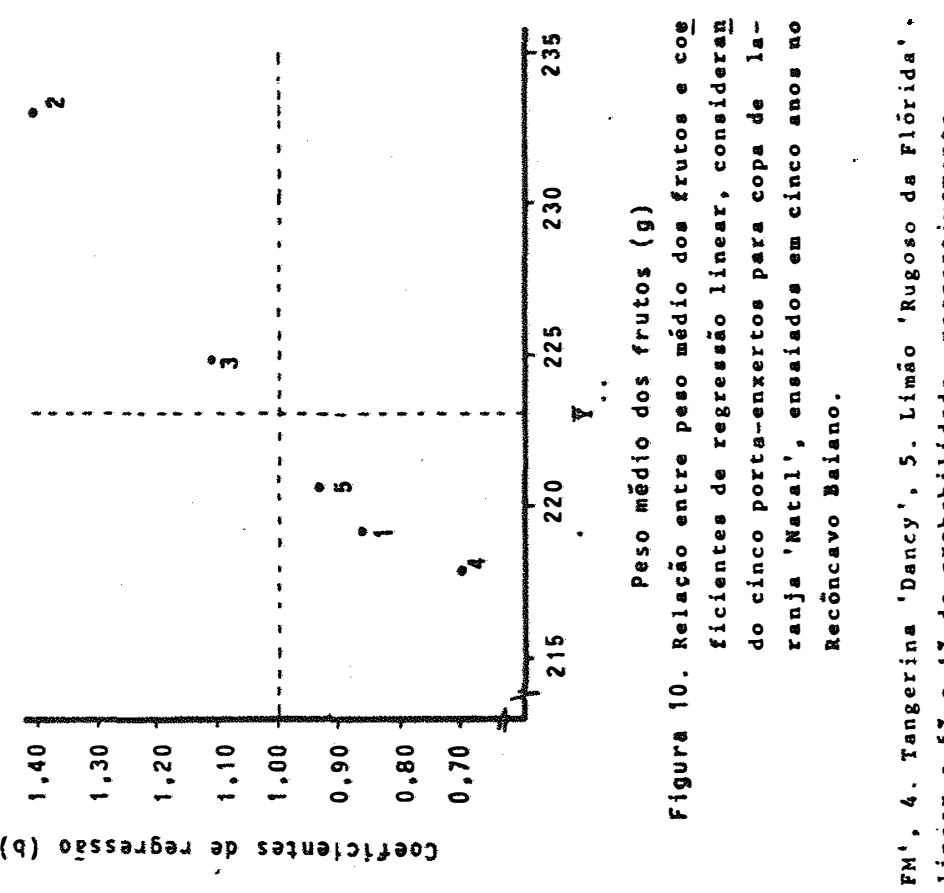

(9) ogssanbad op saquopighoog

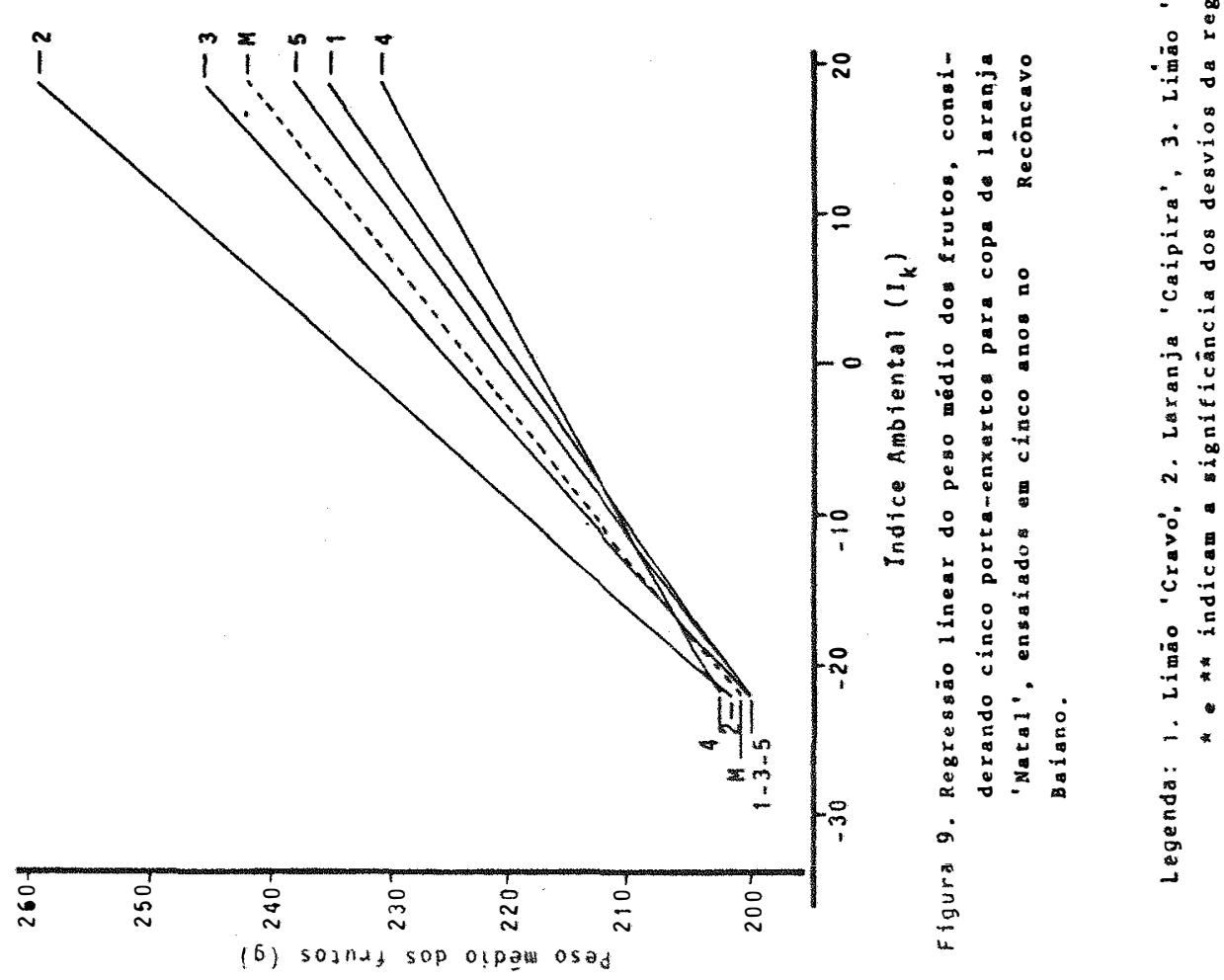




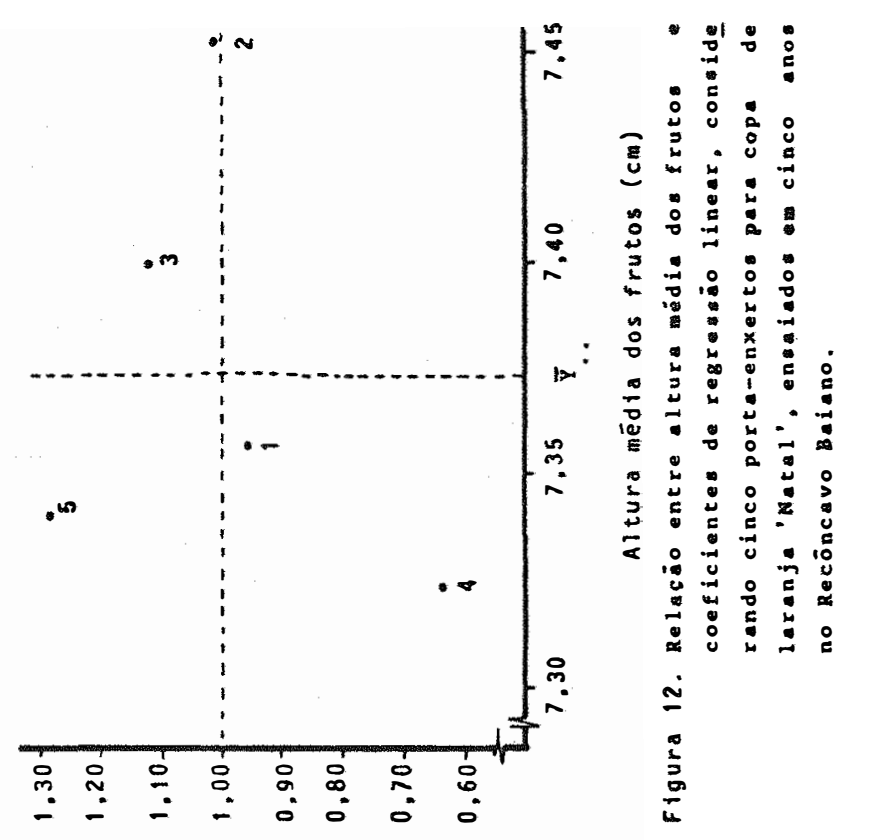

(q) opssadian ap saquatopjaoj

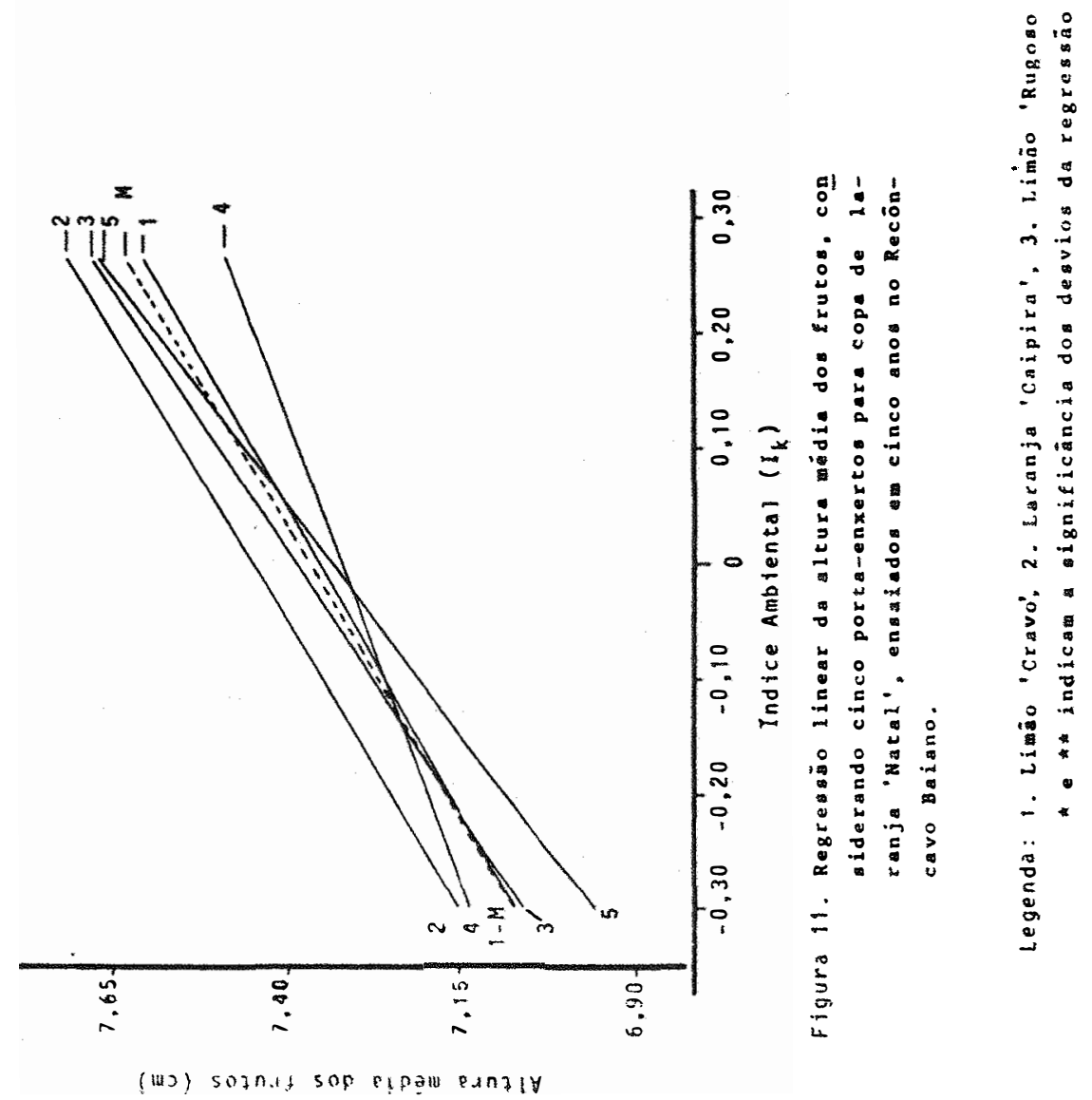


.76 .

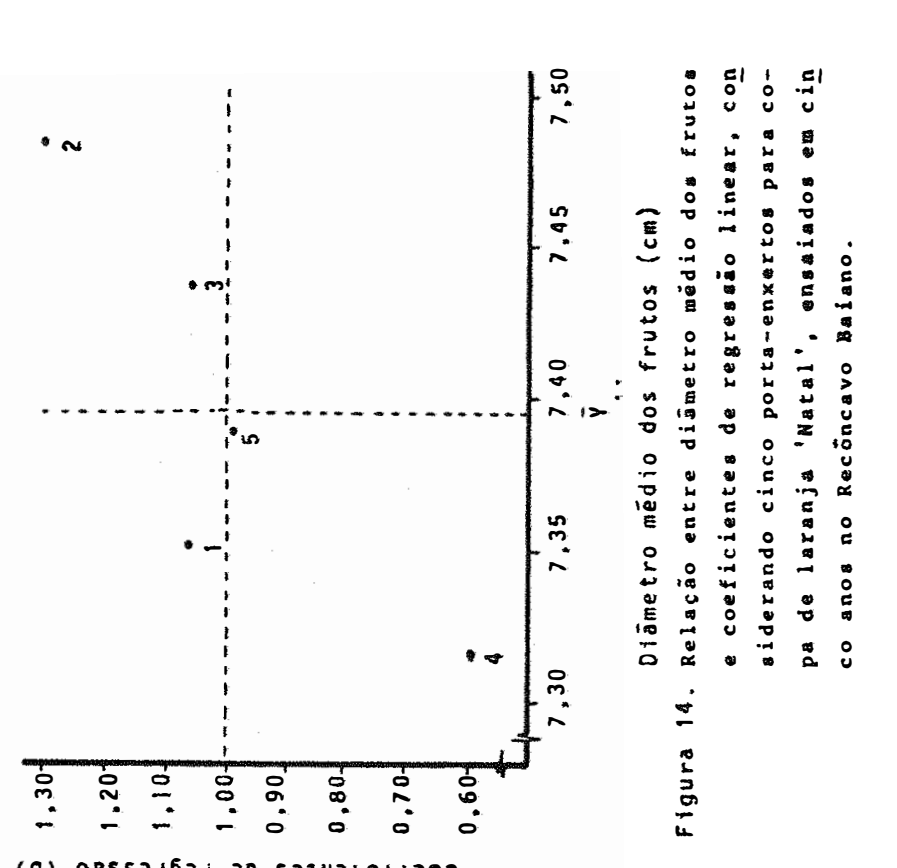

(q) opssan6ad ap 5 aqua!ว!ja0j

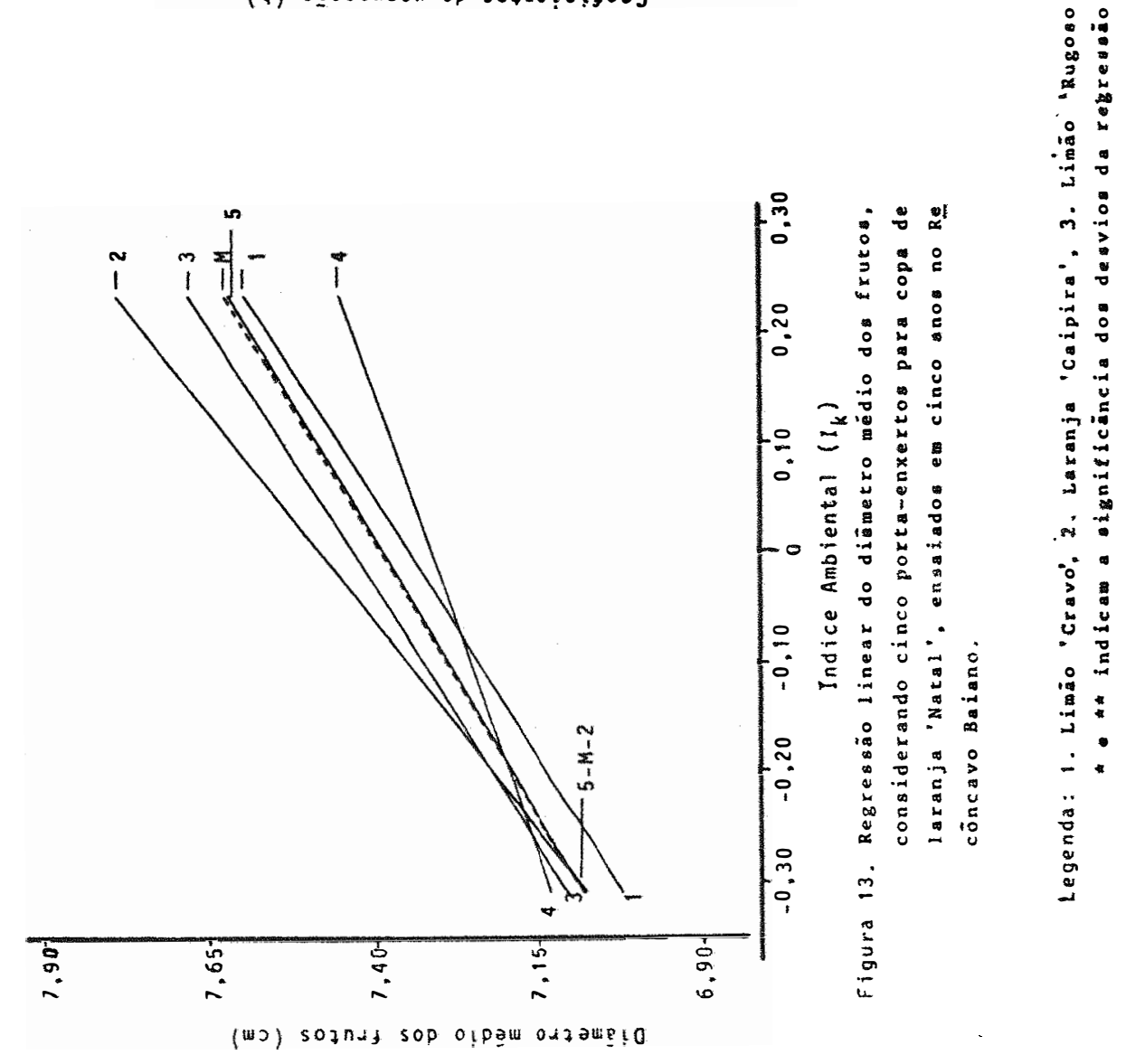


.77.

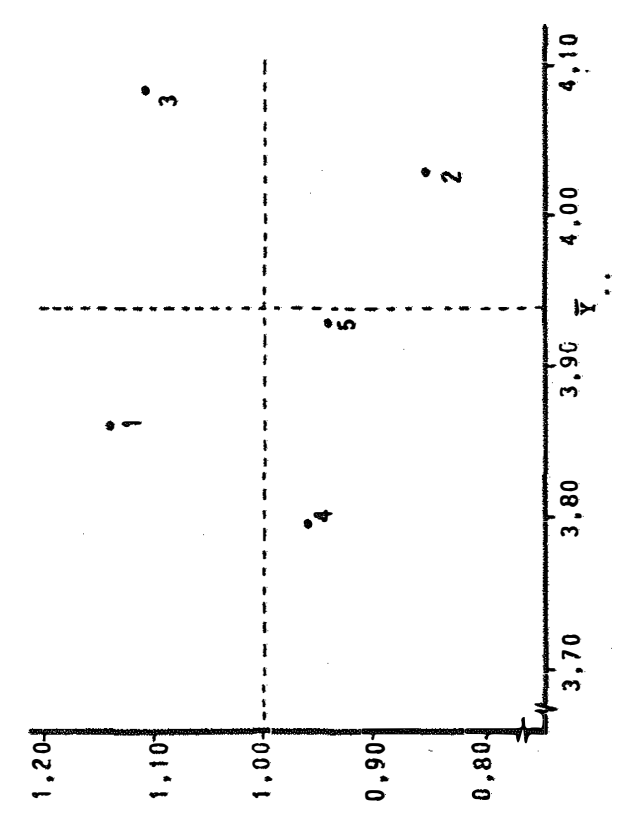

(9) ogssanbaj ap saqua!joja0j
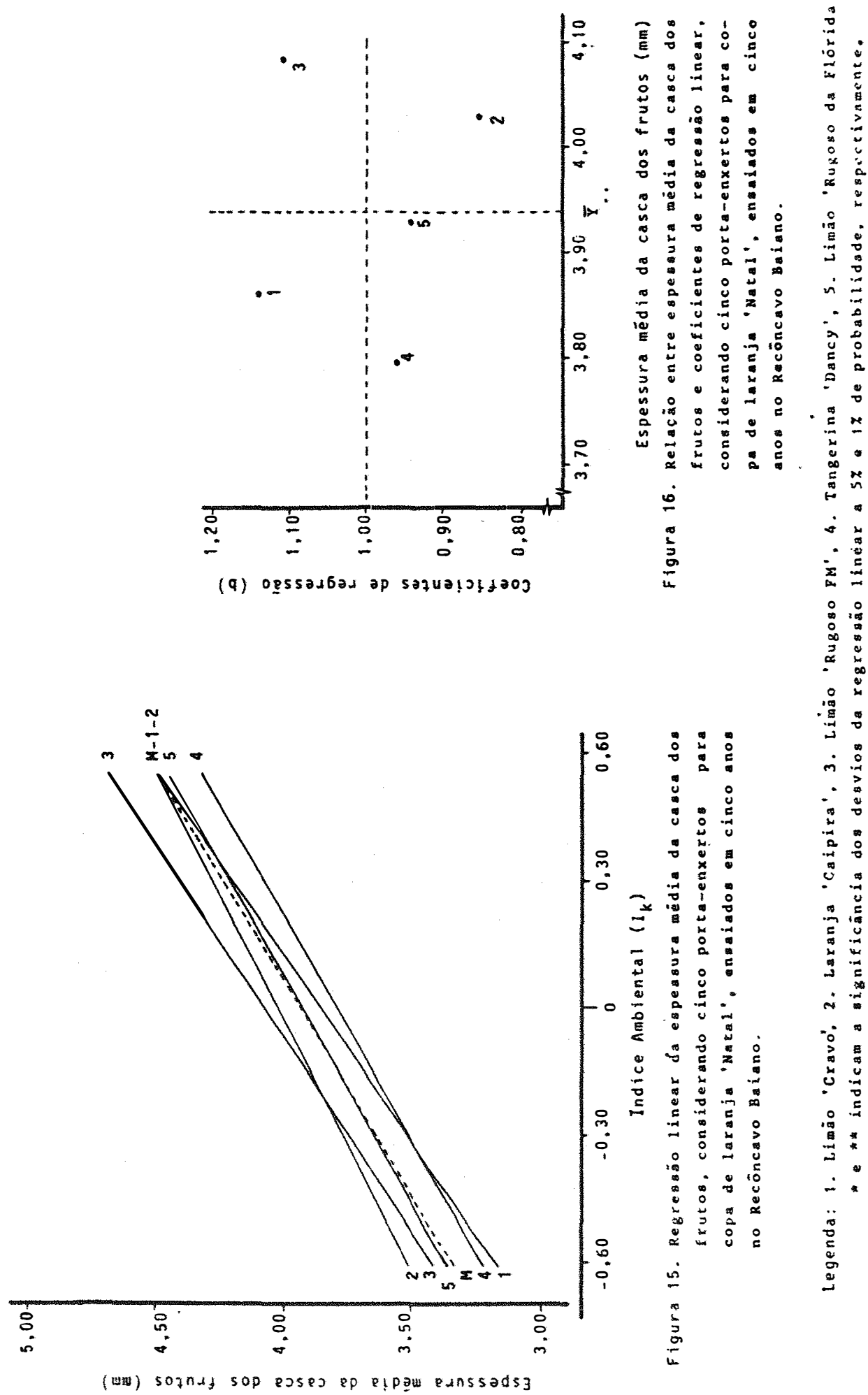

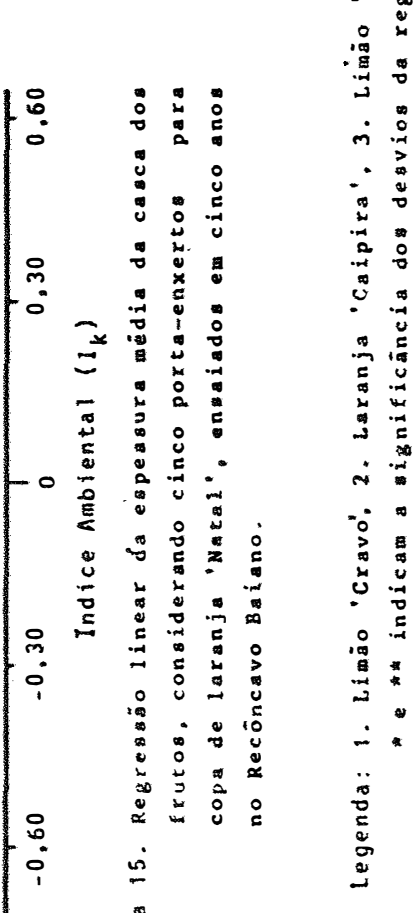

(wW) soznd sop eases ep e!pow ednssads3 


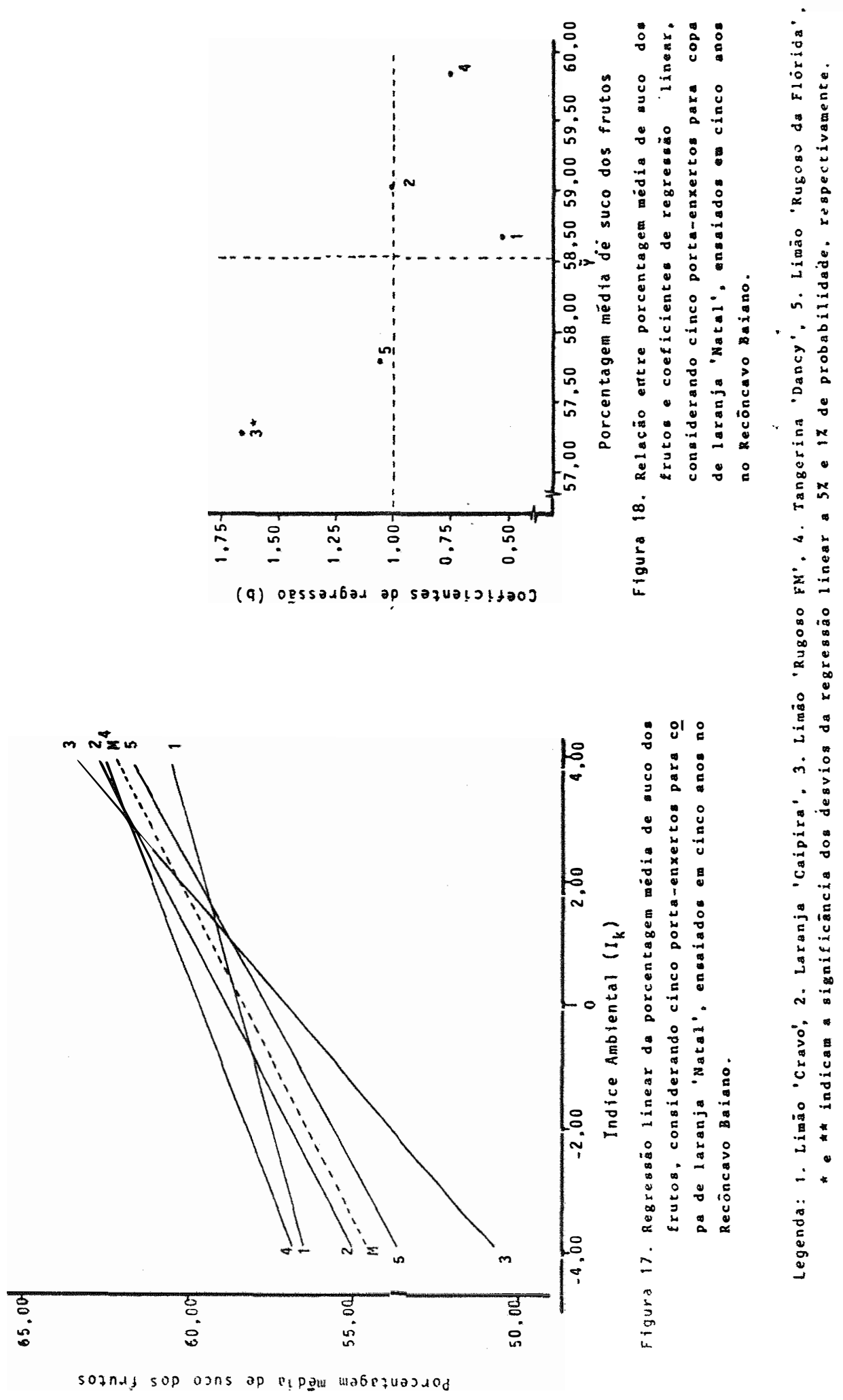




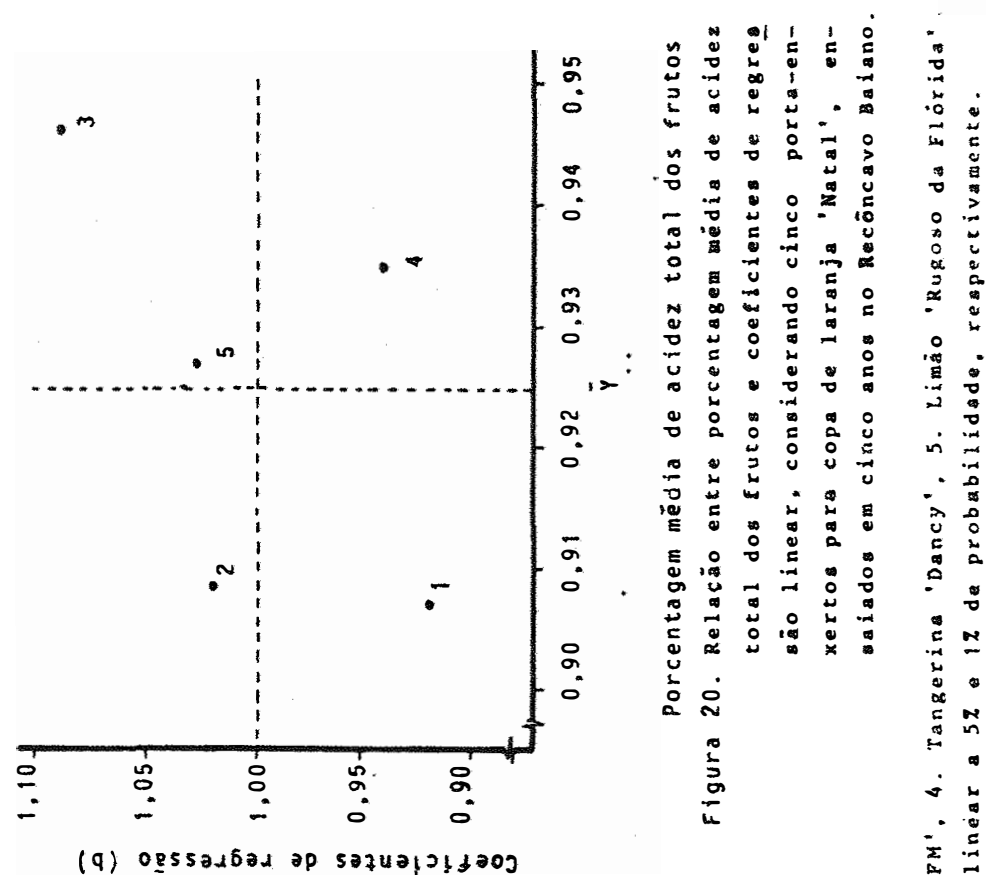

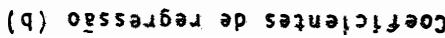

0
0
0
0
0

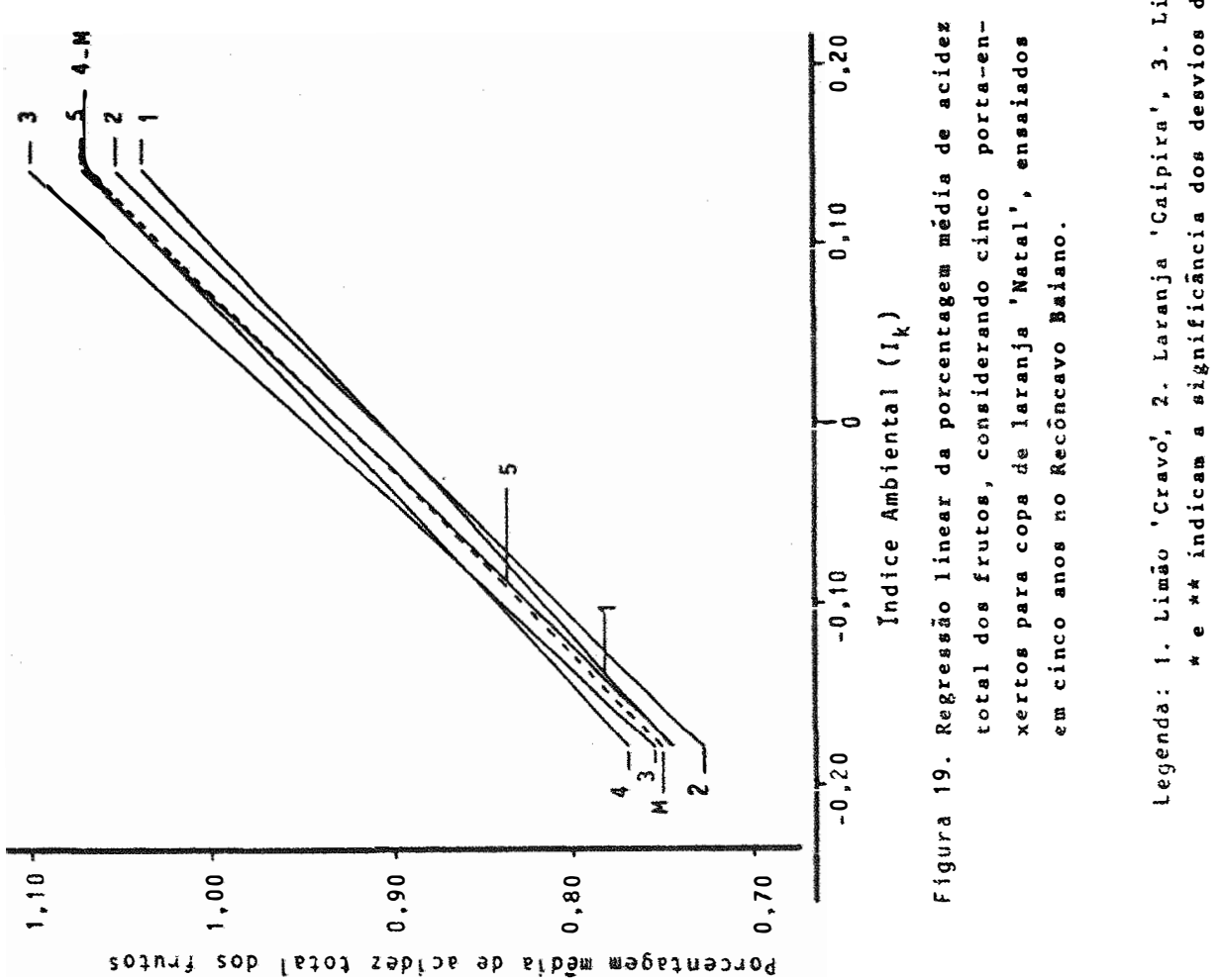




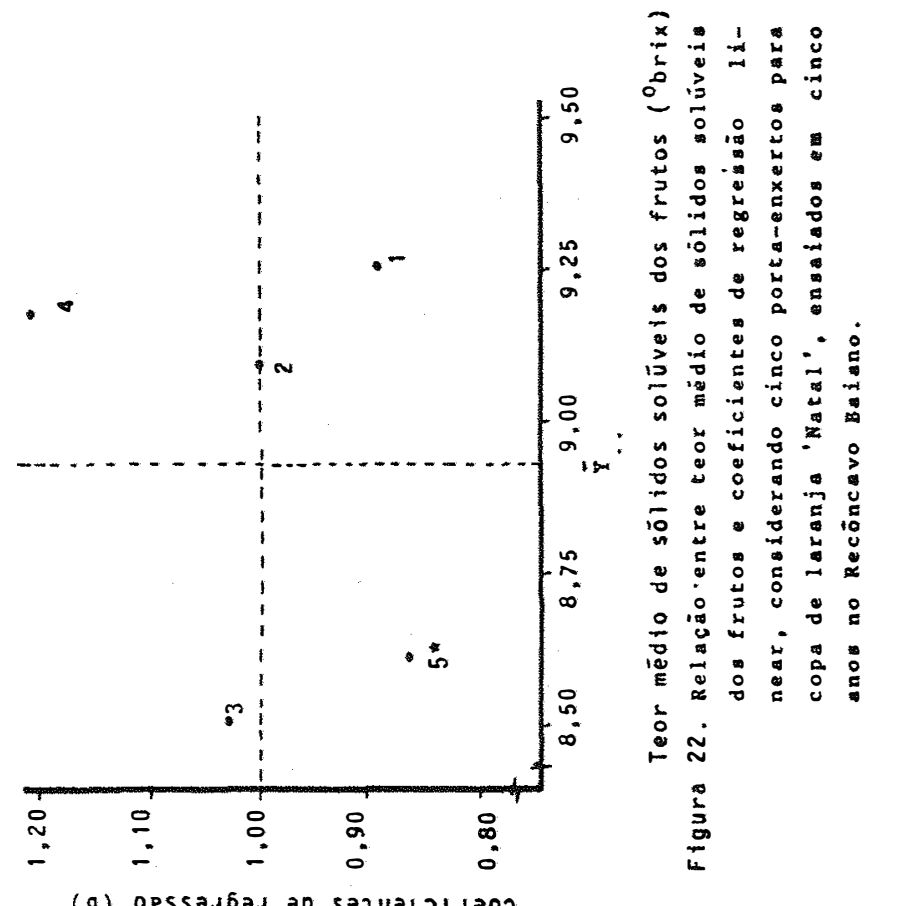

(q) opssanbad ap saqua!jutjaoj

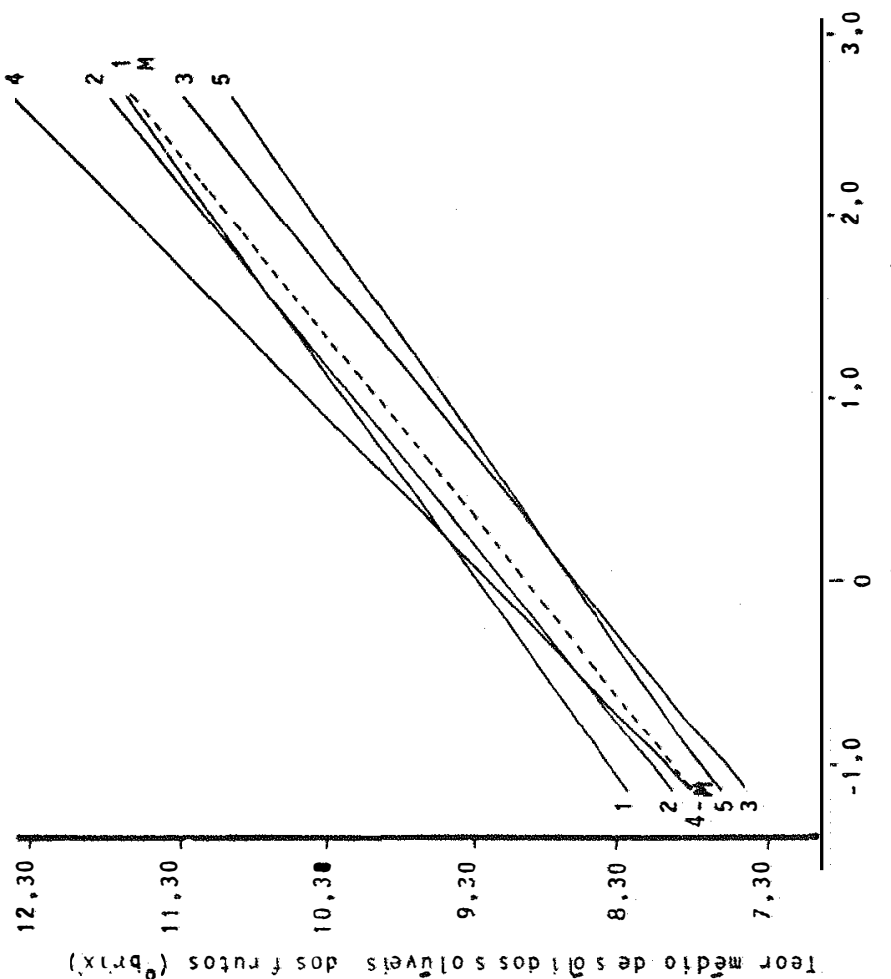

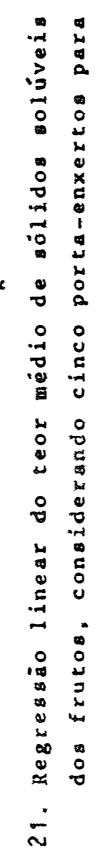

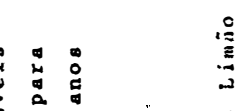

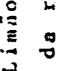

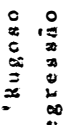

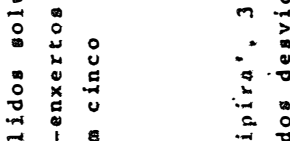

요

:

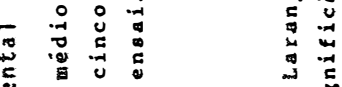

a 0

ह

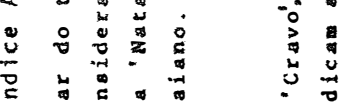

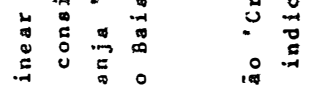

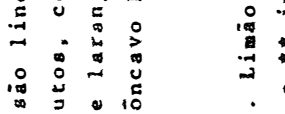

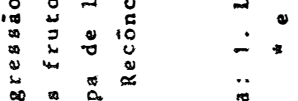

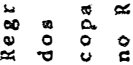

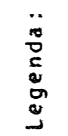


.81.
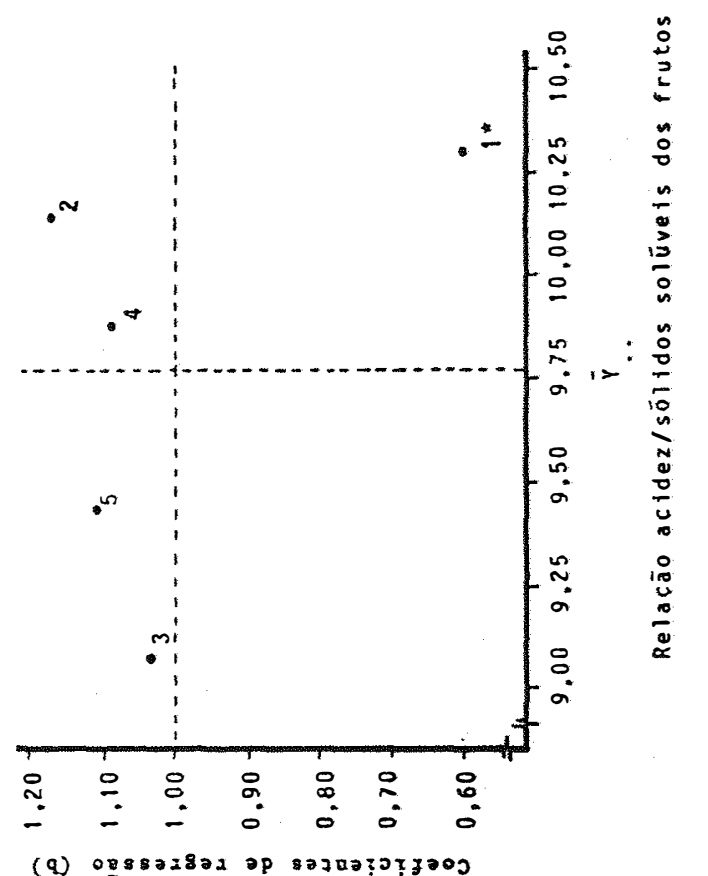

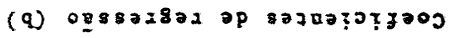

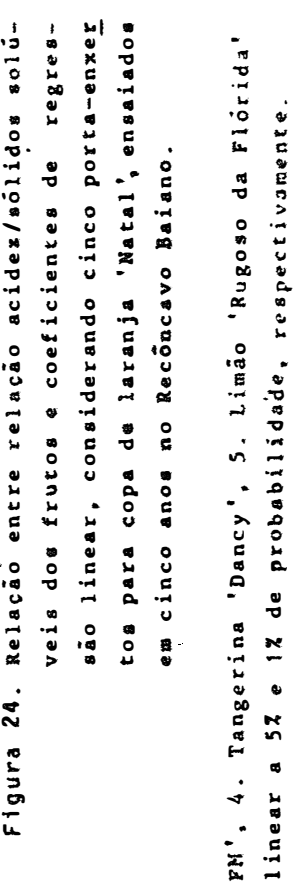

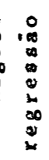

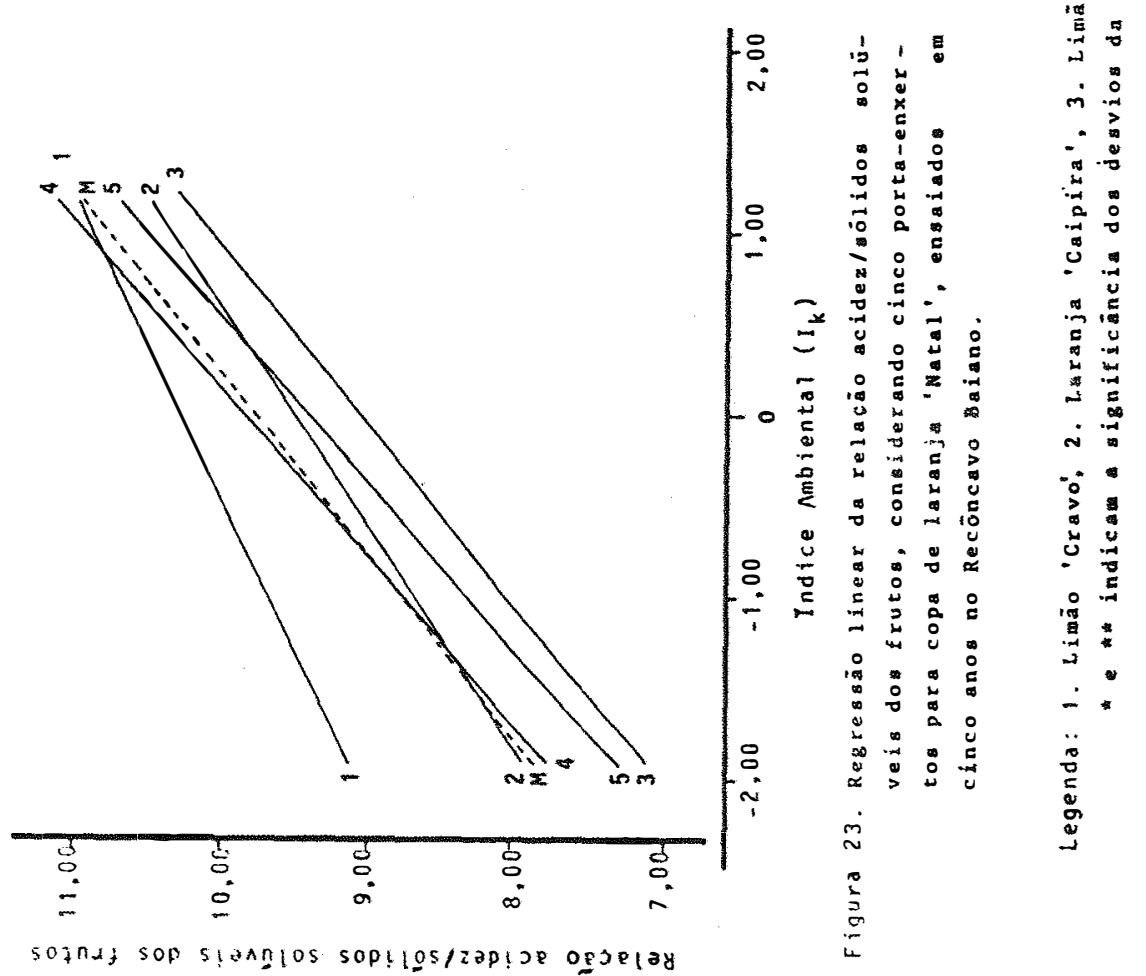




\subsection{Considerações gerais}

Face ao numero de anos abrangidos no presente estudo e à metodologia utilizada, pôde-se avaliar, de maneira pormenorizada, o comportamento das diferentes combinaçós citricas ao longo da maior parte do periodo de vida útil do pomar experimental. A variāncia de anos dentro de porta-enxertos, relativa à totalidade das caracteristicas analisadas, foi explicada, em sua maior parte, pela regressão 1 inear, fato este corroborado pelos elevados valores constatados para os coeficientes de determinaço dos efeitos 1 ineares $\left(R^{2}\right)$, os quais variaram entre um 1 imite minimo de $86,76 \%$ verificado para a relação acidez/sólidos solüveis dos frutos, e um 1 imite máximo superior a $99 \%$, observado para os caracte res de vigor [Tabelas 5 (päg.45), 6 (päg.47), 8 (päg. 55), 9 (päg. 56 ), 11 (päg. 65) e 12 (päg.68)].

Considerando os resultados obtidos, segundo um exame global, os 1 imões rugosos destacaram-se como os "ca valos" que induziram maior produtividade e vigor às copas de laranja 'Natal', a par de uma qualidade de frutos compativel com aquelas apresentadas pelos demais porta-enxertos. Os re feridos genótipos, além disso, manifestaram comportamento pre visivel no que diz respeito à maioria das variáveis estudadas, sendo excecão o teor de sölidos solüveis e a porcentagem de suco dos frutos, respectivamente para os 1 imões 'Rugo so da Flórida' e 'Rugoso FM'. A tangerina 'Dancy', malgrado a previsibilidade de seu comportamento quanto à totalidade das caracteristicas avaliadas, foi o porta-enxerto que deter minou menor produção de frutos, condição esta que, por si só, contra-indica seu emprego em combinações com laranja 'Na tal'. O limão 'Cravo' e a laranja 'Caipira', finalmente, caracterizaram-se por influenciar niveis de produtividade e vi gor intermediários àqueles identificados para os limōes rugo 
sos, num extremo, e a tangerina 'Dancy', no outro. Ambos manifestaram respostas imprevisíveis concernentes à produção e ao vigor das copas (circunferência da copa), sendo que o limão 'Cravo' também apresentou comportamento imprevisível no tocante à relação acidez/sólidos solúveis dos frutos. Com ba se nessas considerações pode-se afirmar, portanto, que os $1 \underline{i}$ mões 'Rugoso da Flórida' e 'Rugoso FM' distinguem-se, dentro do conjunto de genótipos analisados, como os "cavalos" mais recomendáveis para a laranja 'Natal'. Esses resultados, cabe esclarecer, são específicos às condições do experimento.

A metodologia empregada na avaliação daestabi lidade fenotípica dos porta-enxertos incluídos nesta pesquisa, contudo, tem seus inconvenientes, tais como o fato de que os indices utilizados na caracterização dos ambientes provêm de médias calculadas a partirdos próprios dados que estão sendo analisados, comprometendo, desse modo, sua independência (EBERHART e RUSSEL, 1966 e FREEMAN, 1973). Outro aspecto a ser observado refere-se ao processo estatístico em si, que força os resultados no sentido da linearidade e da obtenção de coeficientes de regressão em torno da unidade, conforme jämen cionado. Além disso, as avaliações relativas àqualidade dos frutos teriam maior validade caso fossem efetuadas a partir de frutos que se encontrassem no ponto ideal de colbeita, sen do necessário, para tanto, o estabelecimento prévio das curvas de maturação específicas às diferentes combinações copal porta-enxerto. Muito embora as restrições metodológicas apre sentadas, as informações oferecidas pelo procedimento matemático desenvolvido por EBERHART e RUSSEL (1966) permitem uma identificaçãomais consciente dos genótipos que, dentro de um determinado conjunto, se mostram superiores. Estudos dessa na tureza, convém destacar, são de extrema importância em um programa voltado para a diversificação de porta-enxertos, cuja execução, hämuito, espera por uma definição concreta, tendo-se em vista o iminente perigo que compromete a citricultura brasileira, decorrente do uso quase exclusivo de um único "cavalo", o 1 imão 'Cravo'. 
.84 .

5. CONCLUSÖES

os resultados obtidos no presente trabalho permitem o estabelecimento das seguintes conclusões:

a. A produção de frutos, assim como as características de ví gor da copa e qualidade dos frutos consideradas, apresentaram relações predominantemente lineares frente às varia ções ecológicas anuais.

b. Muito embora a interação porta-enxertos x anos seja explí cada, em grande parte, por efeitos de natureza aditiva, efeitos multiplicativos também se fazem presentes na ação das variações anuais sobre o comportamento da produção das combinações cítricas avaliadas.

c. As magnitudes dos coeficientes de regressão linear e das médias fenotípicas apresentaram, em geral, tendências uni direcionais, particularmente no que concerne aos dados de produção de frutos e vigor da copa, situação esta geralmente observada em outros estudos de estabilidade fenotipica. Considerando-se que a maiorị das avaliações expe- 
rimentais compreendeu plantas em desenvolvimento, pode-se concluir que os coeficientes de regressão associados aos dados de vigor caracterizam a influência dos diferentes porta-enxertos sobre as taxas de crescimento das copas de laranja 'Natal', enquanto que aqueles relacionados aos da dos de produção correspondem a coeficientes de crescimento da produção das combinações cittricas ao longo dos anos.

d. Os porta-enxertos incluídos no presente estudo, em termos gerais, apresentaram comportamentosdiferenciados no que diz respeito ao padrão e previsibilidade de suas respostas às variações anuais, dada a ocorrência de diferenças estatisticamente significativas, ou simplesmente numéricas, verificadas para seus coeficientes de regressão e variâncias dos desvios da regressão, respectivamente. Essa observação é válida tanto para os dados de produção de frutos como para aqueles relativos ao vigor da copa e qua lidade dos frutos.

e. Considerando o conjunto de porta-enxertos analisados, as variáveis referentes à altura da planta, diâmetro do tron co, assim como aquelas associadas ao peso, altura, diâmetro, espessura da casca e porcentagem de acidez total dos frutos, manifestaram comportamentos mais previsíveis em comparação com o que se deu para a produção de frutos, circunferência da copa e demais características de qualidade dos frutos, quais sejam, porcentagem de suco, teor de sólidos solüyeis e relação acidez/sólidos solüveis.

f. A tangerina 'Dancy', no conjunto de porta-enxertos analisados, destacou-se como aquele que apresentou comportamen to previsível para a totalidade das caracteristicas avaliadas, visto que relacionou-se avariâncias dos desvios 
da regressãonãosignificativas. Sua utilização em combi nações com a laranja 'Natal', por êm, $\bar{e}$ contra-indicada co mo decorrência das baixas produções que essa tangerina de terminou às copas.

g. Os limões 'Rugoso da Flörida' e 'Rugoso FM', dentre os cinco "cavalos" compreendidos pelo presente trabalho, foram os que induziram maior vigor e produtividade à copa de laranja' 'Natal', além de manifestarem comportamentopre visível no que tange à maioria das variäveis estudadas, sendo exceção o teor de sólidos solüveis e a porcentagem de suco dos frutos, respectivamente para o primeiro e segundo porta-enxertos mencionados. Com base em um exame global das características avaliadas pode-se concluir que esses genótipos foram aqueles que melhor se comportaramem combinação com a laranja 'Natal', em relação aos demais "cavalos" ensaiados.

h. O limão 'Cravo', porta-enxerto atualmente mais empregado na citricultura brasileira, mostrou-se inadequado ao suporte de copas da referida laranja doce, face à imprevis bilidade do seu comportamento no tocante à produção de frutos, circunferência da copa e relação acidez/sólidos solúveis dos frutos, a par de níveis de produtividade inferiores àqueles constatados para os limões rugosos anteriormente citados, considerando-se as condições do experi mento. Situação semelhante foi verificada para a laranja 'Caipira', exceção feita à previsibilidade do comportamen to da relação acidez/sólidos solüveis dos frutos.

i. O método de araliação da estabilidade fenotípica desenvol vido por Eberhart e Russel, por ter permitido um detalhamento pormenorizado das respostas de cada combinação co- 
pa/porta-enxerto às variações ecológicas anuais, $\vec{e}$ indicado como importante ferramenta auxiliar na identificação de genótipos superiores dentro de um programa de diversificação de porta-enxertos, particularmente em citros e em outras culturas semelhantes. 
.88.

\section{LITERATURA CITADA}

ADAMS, M.W. e D.B. SHANK, 1959. The relationship of heterozygosity to homeostasis in maize hybrids: Genetics. Austin, 44: $777-786$.

ALLARD, R.W., 1961. Relationship between genetic diversity and consistency of performance in different environments. Crop Science. Madison, 1: 127-133.

ALLARD, R.W. e A.D. BRADSHAW, 1964. Implications of genotype-environmental interactions in applied plant breeding. Crop Science. Madison, 4: 503-508.

ALLARD, R.W. e P.L. WORKMAN, 1963. Population studies in predominantly self-pollinated species. IV. Seasonal flutuations in estimated values of genetic parameters in lima bean populations. Evolution. Lawrence, 17: 470480 .

AMARO, A.A., 1982. São Paulo. In: TEÓfllo Sobrinho, J. Ed. Laranja. Cordeirōpolis, Estação Experimental de Limeira! Instituto Agronômico do Estado de São Paulo, p. 69-101. 
BECKER, H.C., 1981. Correlations among some statistical measures of phenotypic stability. Euphytica. Wageningen, 30: $835-840$.

BILBRO, J.D. e L.L. RAY, 1976. Environmental stability and adaptation of several cotton cultivars. Crop Science. Madison, 16: $821-824$.

BONATO, E.R., 1978. Estabilidade fenotípica da produção de grãos de dez cultivares de soja [Glycine max (L.) Merril] nas condições do Rio Grande do Sul. Piracicaba, ESALQ/ USP, $75 \mathrm{p}$. (Dissertação de Mestrado).

BREESE, E.L., 1969. The measurement and significance of genotype-environment interactions in grasses. Heredity. Edinburgh, 24: 27-44.

BUCIO ALANIS, L., 1966. Environmental and genotypeenvironmental components of variability. I. Inbred 1ines. Heredity. Edinburgh, 21: 387-397.

BUCIO ALANIS, L. e J. HILL, 1966. Environmental and genotype-environmental components of variability. II. Heterozygotes. Heredity. Edinburgh, 21: 399-405.

BUCIO ALANIS, L., J.M. PERKINS e J.L. JINKS, 1969. Environmental and genotype-environmental components of variability. V. Segregating generations. Heredity. Edinburgh, 24: 115-127.

BUSH, R.H., J. HAMMOND e R.C. FROHBERG, 1976. Stability and performance of hard red spring wheat bulks for grain yield. Crop Science. Madison, 16: 256-259.

CAMERON, J.W. e H.B. FROST, 1968. Genetics, breeding, and nucellar embriony. In: REUTHER, W.; L. D. BATCHELOR e H.J. WEBBER, Ed. The Citrus Industry. Berkeley, University of California Press, 2: 325-370. 
CASTLE, W.S., 1979. Controlling citrus tree size with rootstocks and viruses for higher density plantings. Proceedings of the Florida State Horticultural Society. Orlando, 91: 46-50.

CASTLE, W.S. e A.H. KREZDORN, 1974. Rootstock effects on root distribution and leaf mineral content of 'Orlando' tangelo trees. Proceedings of the Florida state Horticultural Society. Orlando, 86: 80-84.

CHAPOT, H., 1975. The citrus plant. In: HäFliger, E., Ed. Citrus. Basiléia, CIBA-GEIGY Ltd., p. 6-13.

CHAVES, L.J., 1982. Um modelo não-linear aplicado ao estudo das interações de genótipos com ambientes. Piracicaba, ESALQ/USP, 102 p. (Dissertação de Mestrado).

COCKERHAM, C.C., 1961. Implications of genetic variances in a hybrid breeding program. Crop Science. Madison, 1: 47-52.

COMSTOCK, R.E., 1955. Theory of quantitative genetics: synthesis. Cold Spring Harbor Symposia on Quantitative Biology. New York, 20: 93-102.

COMSTOCK, R.E. e R.H. MOLL, 1963. Genotype-environment interactions. In: HANSON, W. D. e H.F. ROBINSON, Ed. Statistical Genetics and Plant Breeding. Washington, National Academy of Sciences, p. 164-196.

COOK, J.A.; G.E. HORANIC e F.E. GARDNER, 1952. Citrus rootstock trials. Proceedings of the Florida state Horticultural Society. Orlando, 65: 69-77. 
CUNHA Sobrinho, A.P. da; W. dos S. SOARES Filho e O.S. PASsos, 1978. Porta-enxertos para laranja 'Baianinha' [Citrus sinensis (L.) osbeck]. Revista Brasileira de Fruti cultura. Cruz das Almas, $1(3): 17-24$.

CUNHA Sobrinho, A.P. da; W. dos S. SOARES Filhoe O.S. PASSos, 1980. Porta-enxertos para citros. Circular técnica 3, Cruz das Almas, EMBRAPA/CNPMF. $16 \mathrm{p}$.

DORNELLES, C.M.M., 1981. Porta-enxertos para mandarinas (C $\underline{i}$ trus deliciosa Tenore) no Rio Grande do Sul. In: VI Con gresso Brasileiro de Fruticultura. Anais. Recife, Socie dade Brasileira de Fruticultura, 2: 702-708.

EASTON, H.S. e R.J. CLEMENTS, 1973. The interaction of wheat genotypes with a specific factor of the environment. Journal of Agricultural science. Cambridge, 80: 43-52.

EBERHART, S.A. e W.A. RUSSEL, 1966. Stability parameters of comparing varieties, Crop Science. Madison, 6: 36-40.

EBERHART, S.A. e W.A. RUSSEL, 1969. Yield and stability for a 10-line diallel of single-cross and double-cross maize hybrids. Crop Science. Madison, 9: 357-361.

EBERHART, S.A.; W.A. RUSSEL e L.H. PENNY, 1964. Double cross hybrid prediction in maize when epistasis is present. Crop Science. Madison, 4: 363-366.

EMPRESA BRASILEIRA DE PESQUISA AgROPECUÁRIA. Serviço Nacional de Levantamento e Conservação de Solos, 1977. Levantamento exploratório-reconhecimento de solos da margem di reita do Rio São Francisco; Estado da Bahia. Rio de Janeiro, p. 136-137. (Boletim Técnico, 52). 
FIgUEIREDO, J.0. de; J. POMPEU Junior; 0. RODRIGUEZ, A.A. CAETANO; T.R. ROCHA e T. IGUE, 1981. Competição de dez porta-enxertos para laranjeira-barão Citrus sinensis ( $L$. ) Osbeck. In: VI Congresso Brasileiro de Fruticultura. Anais. Recife, Sociedade Brasileira de Fruticultura, 2 : 501-516.

FINLAY, K.W. e G.N. WILKINSON, 1963. The analys is of adaptation in a plant-breeding programme. Australian Journal of Agricultural Research. Victoria, 14: 742-754.

FISHER, R.A. e W.A. MACKENZIE, 1923. Studies in crop variation. II. The manurial response of different potato varieties. Journal of Agricultural Science. Cambridge, 13: $311-320$.

FREEMAN, G.H., 1973. Statistical methods for the analysis of genotype-environment interactions. Heredity. Edinburgh, 31: $339-354$.

FREY, K.J., 1972. Stability indexes for isolines of oats (Avena sativa L.). Jrop Science. Madison, 12: 809-812.

FREY, K.J.eU. MALDONADO, 1967. Relative productivity of homogeneous and heterogeneous oat cultivars in optimum and suboptimum environments. Crop Science. Madison, I: 532-535.

HALDANE, J.B.S., 1954. The Biochemistry of Genetics. London, George Allen \& Unwin Ltd. $144 \mathrm{p}$.

HANSON. W.D., 1970. Genotypic stability. Theoretical and Applied Genetics. Berlin, 40:226-231.

HEARN, C.J.; D.J. HUTCHINSON e H.C. BARRET, 1974. Breeding citrus rootstocks. Hortscience. Mount Vernon, 9: 357-358. 
JAIN, S.K. e R.W. ALLARD, 1960. Population studies in predominantly self-pollinated species, I. evidence for heterozygote advantage in a closed population of barley. Proceedings of the National A cademy of Sciences. Washington D.C., 46: 1371-1377.

JENSEN, N.F., 1952. Intra-varietal diversification in oat breeding. Agronomy Journal. Madison, 44: 30-34.

JOWETT, D., 1972. Yield stability parameters for sorghum in East Africa. Crop Science. Madison, 12: 314-317.

KALIL Filho, A.N., 1982. Potencial de produtividade e estabilidade fenotípica na caracterização de clones de seringueira (Hevea spP.). Piracicaba, ESALQ/USP, 116 p. (Dissertação de Mestrado).

KNIGHT, R., 1970. The measurement and interpretation of genotype-environment interactions. Euphytica. Wageningen, 19: $225-235$.

LERNER, I.M. , 1954. Genetic Homeostasis. Edinburgh, Oliver and Boyd. $134 \mathrm{p}$.

LEVINS, R., 1963. Theory of fitness in a heterogeneous environment. II. Developmental flexibility and niche selection. American Naturalist. Tempe, 97: 75-90.

LEWIS, D., 1954. Gene-environmental interaction: a relationship between dominance, heterosis, phenotypic stability and variability. Heredity. Edinburgh, 8: 333356 .

LEWONTIN, R.C., 1957. The adaptations of populations to varying environments. Cold Spring Harbor Symposia on Quantitative Biology. New York, 22: 395-408. 
MAGALHÃES, A.C. e W.J. da SILVA, 1978. Determinantes genétí co-fisiológicos da produtividade do milho. In: PATERNIANI, E., Coord. Melhoramento e Produsão do Mi.tho no Brasiz. Piracicaba/ESALQ, Marprint, p. 349-375.

MARIOTTI, J.A.; E.S. OYARZABAL; J.M. OSA; A.N.R. BULACIO e G.H. ALMADA, 1976. Analisis de estabilidad y adaptabilidad de genotipos de caña de azucar. I. Interacciones den tro de una localidad experimental. Revista Agronomica Del Nordeste Argentino. Tucuman, 8: 105-118.

MATHER, K., 1953. Genetical control of stability in development. Heredity. Edinburgh, 7: 297-336.

MENDES, L.O.T., 1936. A maturação dos frutos citricos. São Paulo, Secretaria da Agricultura, Indústria e Comércio. 9 p.

MONTENEGRO, H.W.S.; S. MOREIRA; F.P. GOMES e B. CINTRA, 1959. Influência do porta-enxerto no nümero de sementes da 1 aranja. In: Anais da ESALQ. Piracicaba/USP, 16: 79-85.

MONTENEGRO, H.W.S.; S. MOREIRA; V.G. de OLIVEIRA e F.P. GOMES, 1961. Influência da interagão enxêrto "cavalo" sobre algumas caracteristicas fisico-quimicas da laranja. Piracicaba, ESALQ. 15 p. (Boletim, 18).

MOREIRA, S., 1980. História da citricultura no Brasil. In: RODRIGUEZ, O. e F. VIEGAS, Coord. Citricultura Brasizeira. Campinas, Fundação Cargil1, 1: 1-28.

MOREIRA, S.; V.G. OLIVEIRA e E. ABRAMIDES, 1960. Experimentos de cavalos para citros. III. Bragantia. Campinas, 19: $961-995$.

NASPOLINI Filho, V., 1975. Variabilidade fenotipica e estabilidade em híbridos simples, híbridos duplos, variedades e compostos de milho (zea mays L.). Piracicaba, ESALQ/USP, $68 \mathrm{p}$. (Dissertação, de Mestrado). 
OLIVEIRA, A.C. de, 1976. Comparação de alguns métodos de de terminação da estabilidade em plantas cultivadas. Brasi lia, UnB, 64 p. (Dissertação de Mestrado).

PALOMO G.,A. e J. MOLINA G., 1975. Estabilidad del rendimiento en variedades del algodonero (G. hirsutum L.) para la Comarca Lagunera. Agrociêneia. Chapingo, no 21 , p. $67-76$.

PARENTE, T.V.; J.K. de A. MATTOS e F.C.C. SILVA, 1981. Competição de 14 porta-enxertos para tangerineira Ponkan em solo de cerrado a nivel de viveiro. In: VI Congresso Brasileiro de Fruticultura. Anais. Recife, Sociedade Brasileira de Fruticultura, 2: 517-529.

PARODA, R.S. e J.D. HAYES, 1971. An investigation of genotype-environment interactions for rate of ear emergence in spring barley. Heredity. Edinburgh, 26: 157175 .

PASSOS, O.S.; A.P. da CUNHA Sobrinho e Y. da S. COELHO, 1973. Comportamento de Poncirus trifoliata (I.) Raf. no Estado da Bahia. In: II Congresso Brasileiro de FruticuI tura. Anais. Viçosa, Sociedade Brasileira de Fruticultura, 1: 149-157.

PASSOS, O.S.; A.P. da CUNHA Sobrinho e Y. da S. COELHO, 1976. Comportamento de híbridos e seleções de Poncirus trifoliata (L.) Raf. e de outros porta-enxertos no Estado da Bahia. In: II Congresso Brasileiro de Fruticultura. Anais. Rio de Janeiro, Sociedade Brasileira de Fruticultura, 1: $77-90$.

PATANOTHAI, A. e R.E. ATKINS, 1974. Yield stability of single crosses and three-way hybrids of grain sorghum. Crop Science. Madison, 14: 287-290. 
PERKINS, J.M. e J.L. JINKS, 1968. Environmental and genotype-environmental components of variability. III. Multiple Iines and crosses. Heredity. Edinburgh, 23: 339-356.

PFAHLER, P.L., 1972. Relationship between grain yield and environmental variability in oats (Avena sp.). Crop Science. Madison, 12: 254-255.

PFAHLER, P.L. e H.F. LISKENS, 1979. Yield stability and population diversity in oats (Avena sp.). Theoretical and Applied Genetics. Berlin, 54: 1-5.

PIMENTEL GOMES, F., 1976. Curso de Estatistica Experimental. 6. ed. Piracicaba, Livraria Nobel S/A. $430 \mathrm{p}$.

PLAISTED, R.L., 1960. A shorter method for evaluating the ability of selections to yield consistently over locations. American Potato Journal. New Brunswick, 37 : $166-172$.

PLAISTED, R.L. e L.C. PETERSON, 1959. A technique for evaluating the ability of selections to yield consistently in different locations or seasons. American Potato Journal. New Brunswick, 36: 381-385.

POMPEU Junior, J.; J.0. de FIGUEIREDO; J. ALOISI Sobrinho; T.IGUE e A.A. SALIBE, 1981. Comportamento da laranjeira-valéncia Citrus sinensis (L.) osbeck, em 18 porta-enxertos. In: VI Congresso Brasileiro de Fruticultura. Anais. Recife, Sociedade Brasileira de Fruticultura, 2 : 530-541.

POMPEU Junior, J.; J.O. de FIGUEIREDO; J. TEÓFIlO Sobrinho; J. de P. N. JORGE e A.A. SALIBE, 1978. Porta-enxertos Pa ra laranjeira-hamlin. In: Iv Congresso Brasileiro de Fruticultura. Anais. Salvador, Sociedade Brasileira de Fruticultura, p. 105-110. 
PROBST, A.H., 1957. Performance of variety blends in soybeans. Agronomy Journal. Madison, 49: 148-150.

QUISENBERRY, J.E. e R, J. KOHEL, 1971. Phenotypic stability of cotton. Crop Science. Madison, 11: 827-829.

RASMUSSON, D.C. e J.W. LAMBERT, 1961. Variety x environment interactions in barley variety tests. Crop science. Madison, 1: 261-262.

REICH, V.H. e R.E. ATKINS, 1970. Yield stability of four population types of grain sorghum, Songhum bicolon (L.) Moench, in different environments. Crop Science. Madison, 10: $511-517$.

ROWE, P.R. e R.H. ANDREW, 1964. Phenotypic stability for a systematic series of corn genotypes. Crop Science. Madison, 4 : 563-567.

SALIBE, A.A., 1978. Importância do porta-enxerto na citricultura. In: VEncontro Nacional de Citricultura. Rio de Janeiro, PESAGRO - Sociedade Brasileira de Fruticultu$\mathrm{ra}, 14 \mathrm{p}$.

SALIBE, A.A. e M.M. MISCHAN, 1978. Efeito do porta-enxerto e da localidade nas características de cinco variedades de laranja doce, Citrus sinensis (L.) osbeck. In: IV Congresso Brasileiro de Fruticultura. Anais. Salvador, Sociedade Brasileira de Fruticultura, p. 93-104.

SALIBE, A.A. e M.M. MISCHAN, 1981. Comportamento do 1 imoeiro feminello santa teresa enxertado sobre limoeiro cravo e sobre quatro seleções de limoeiro volkameriano. In: VI Congresso Brasileiro de Fruticultura. Anais. Recife, Sociedade Brasileira de Fruticultura, 2: 542-551. 
SAMUEL, C.J.A.; J. HILL; E.L. BREESE e A. DAVIES, 1970. Assessing and predicting environmental response in Lolium perenne. Journal of Agricultural Science. Cambridge, 75: $1-9$.

SANTOS, J.B. dos, 1980. Estabilidade fenotípica de cultivares de feijão (Phaseolus vulgaris L.) nas condições do sul de Minas Gerais. Piracicaba, ESALQ/USP, 110 p. (Dissertação de Mestrado).

SERAPHIN, J.C., s.d. Um método de determinação da estabilidade em plantas: seminário. Piracicaba, ESALQ/Departamen to de Matemática e Estatistica, $20 \mathrm{p}$.

SNEDECOR, G.W., 1957. Statistical Methods. 5, Ames, Iowa State College Press. 534 p.

SOARES Filho, W. dos S.; CUNHA Sobrinho; A.P. da e O.S. PASsos, 1980. Porta-enxertos para laranja 'Natal'. Pesqui sa A gropecuária Brasileira. Brasília, 15: 471-474.

SPRAGUE, G.F. e W.T. FEDERER, 1951. A comparison of variance components in corn yield trials: II. Error, year $x$ variety, location $x$ variety, and variety components. Agronomy Journal. Madison, 43: 535-541.

STEEL, R.G.D. e J.H. TORRIE, 1960. Principles and Procedures of Statistics. New York, Mc Graw Hill Book Company, Inc. 481 p.

St-PIERRE, C.A.; H.R. KLINCK e F.M. GAUTHIER, 1967. Early generation selection under different environments as it influences adaptation of barley. Canadian Journal of Plant science. Ottawa, 47: 507-517. 
TAI, G.C.C., 1971. Genotypic stability analysis and its application to potato regional trials. Crop Science. Madison, 11: 184-190.

TEర́fILO Sobrinho, J.; S. SIMÃO; D. BARBIN e J. POMPEU Junior, 1973. Produtividade por metro cúbico e vigor da laranjei ra-valência sobre diferentes porta-enxertos. In: II Con gresso Brasileiro de Fruticultura. Anais. Viçosa, Sociedade Brasileira de Fruticultura, 1: 331-341.

VENCOVSKY, R., 1978. Herança quantitativa. In: PATERNIANI, E., Coord. Melhoramento e Producão do Milho no Brasil. Piracicaba/ESALQ, Marprint, p. 122-201.

VENCOVSKY, R. e I.0. GERALDI, 1977. Um modelo multiplicativo aplicado à anälise de produção de grãos. Relatório Cientifico do Departamento de Genética e Instituto de Genética. Piracicaba, ESALQ/USP, 11: 157-165.

VERMA, M.M. ; B.R. MURTY e H. SINGH, 1972. Adaptation and genetic diversity in soybean. Indian Journal of Genetics and Plant Breeding. New Delhi, 32: 266-275.

WUTSCHER, H.K. e A.V. SHULL, 1976. Performance of 'Marrs' early orange on eleven rootstocks in South Texas. Journal of the American Society for Horticultural Science. Mount Vernon, 101: 158-161.

YATES, F. e W.G. COCHRAN, 1938. The analysis of groups of experiments. Journal of Agricultural Science. Cambridge, 28: $556-580$. 
.100

GLOSSARIO 


\section{GLOSSARIO}

- Nomenclatura comum e cientifica de cultivares e tipos híbridos, relativa aos materiais cítricos citados no texto.

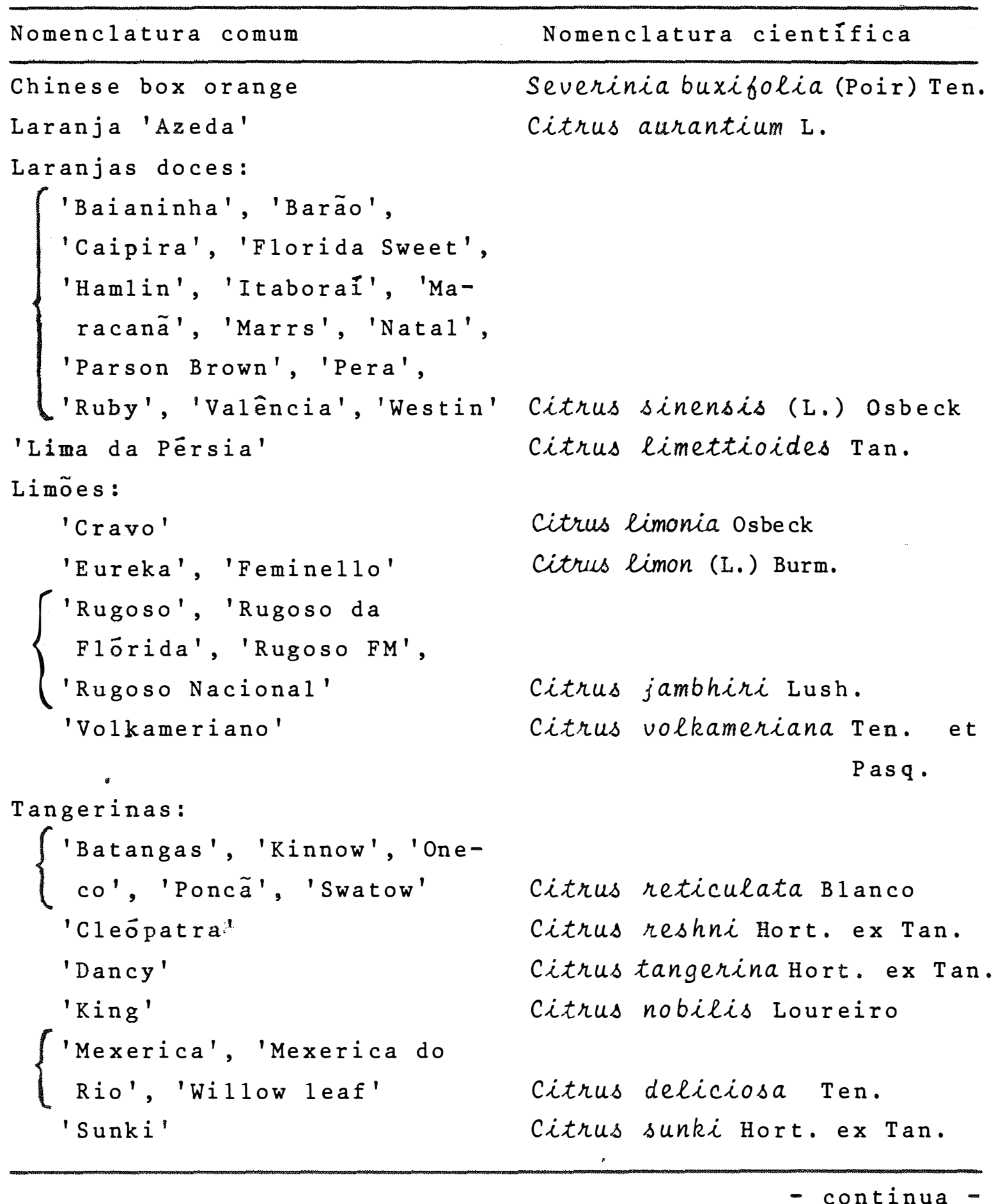


continuação

\begin{tabular}{|c|c|c|}
\hline Nomenclatura & comum & Nomenclatura cientifica \\
\hline Trifoliata & & Poncirus trifoliata (L.) Raf. \\
\hline Citrandarin & & $\begin{array}{l}\text { Poncirus trifoliata } \times \text { citrus } \\
\text { reticulata }\end{array}$ \\
\hline Citrange & - & $\begin{array}{l}\text { Poncirus trifoliata } \times \text { citrus } \\
\text { sinensis }\end{array}$ \\
\hline Citrumelo & & $\begin{array}{l}\text { Citrus paradisi Macf. x Ponci- } \\
\text { rus trifoliata }\end{array}$ \\
\hline Tange 10 & & $\begin{array}{l}\text { Citrus reticulata } \times \text { Citrus } \\
\text { paradisi }\end{array}$ \\
\hline
\end{tabular}


.103.

$A N E X O$ 
.104.

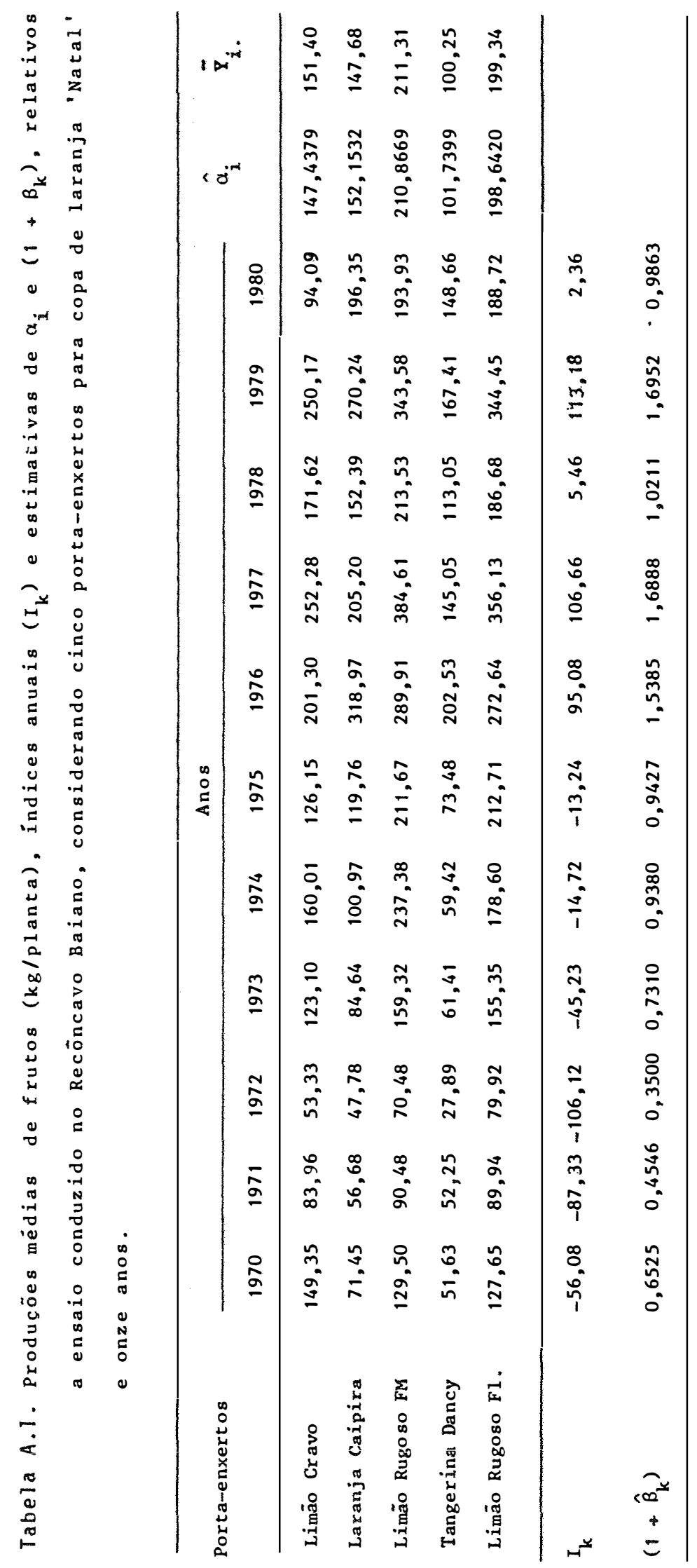


.105.

Tabela A.2. Valores médios de circunferēncia da copa, altura da planta e diámetro do tronco, com os respectivos indices anuais $\left(I_{k}\right)$, relativos a ensaio conduzido no Recōncavo Baiano, considerando cinco porta-enxertos para copa de laranja 'Natal' e cin co anos.

\begin{tabular}{|c|c|c|c|c|c|}
\hline \multirow{2}{*}{ Porta-enxertos } & \multicolumn{5}{|c|}{ Anos } \\
\hline & 1965 & 1969 & 1975 & 1977 & 1980 \\
\hline & \multicolumn{5}{|c|}{ Circunferência da copa } \\
\hline $\begin{array}{l}\text { Limão Cravo } \\
\text { Laranja Caipira } \\
\text { Limão Rugoso FM } \\
\text { Tangerina Dancy } \\
\text { Limão Rugoso F1. }\end{array}$ & $\begin{array}{l}1,534 \\
1,284 \\
1,450 \\
1,080 \\
1,428 \\
\end{array}$ & $\begin{array}{l}9,594 \\
6,940 \\
9,808 \\
7,180 \\
9,632 \\
\end{array}$ & $\begin{array}{l}14,254 \\
13,164 \\
15,764 \\
11,736 \\
15,526 \\
\end{array}$ & $\begin{array}{l}14,380 \\
13,860 \\
16,504 \\
12,010 \\
15,938 \\
\end{array}$ & $\begin{array}{l}14,832 \\
14,434 \\
17,444 \\
13,250 \\
16,834 \\
\end{array}$ \\
\hline \multirow[t]{2}{*}{$I_{k}$} & $-9,44$ & $-2,16$ & 3,29 & 3,74 & 4,56 \\
\hline & \multicolumn{5}{|c|}{ Altura da planta } \\
\hline $\begin{array}{l}\text { Limão Cravo } \\
\text { Laranja Caipira } \\
\text { Limão Rugoso FM } \\
\text { Tangerina Dancy } \\
\text { Limão Rugoso Fl. }\end{array}$ & $\begin{array}{l}1,268 \\
1,100 \\
1,242 \\
1,132 \\
1,256 \\
\end{array}$ & $\begin{array}{l}3,148 \\
2,810 \\
3,282 \\
2,782 \\
3,182 \\
\end{array}$ & $\begin{array}{l}3,570 \\
3,544 \\
4,026 \\
3,040 \\
3,904 \\
\end{array}$ & $\begin{array}{l}3,088 \\
3,080 \\
3,530 \\
2,710 \\
3,412 \\
\end{array}$ & $\begin{array}{l}3,340 \\
3,342 \\
3,802 \\
3,100 \\
3,840 \\
\end{array}$ \\
\hline \multirow[t]{2}{*}{$I_{k}$} & $-1,70$ & 0,14 & 0,72 & 0,26 & 0,58 \\
\hline & \multicolumn{5}{|c|}{ Diâmetro do tronco } \\
\hline $\begin{array}{l}\text { Limão Cravo } \\
\text { Laranja Caipira } \\
\text { Limão Rugoso FM } \\
\text { Tangerina Dancy } \\
\text { Limão Rugoso Fl. }\end{array}$ & $\begin{array}{l}2,12 \\
1,88 \\
2,06 \\
1,56 \\
2,04 \\
\end{array}$ & $\begin{array}{r}10,10 \\
8,60 \\
11,52 \\
8,02 \\
10,92 \\
\end{array}$ & $\begin{array}{l}14,84 \\
14,16 \\
17,02 \\
12,90 \\
16,34 \\
\end{array}$ & $\begin{array}{l}16,30 \\
16,00 \\
18,24 \\
14,54 \\
17,80 \\
\end{array}$ & $\begin{array}{l}17,36 \\
17,52 \\
19,84 \\
16,42 \\
19,90 \\
\end{array}$ \\
\hline$I_{k}$ & $-10,39$ & $-2,49$ & 2,73 & 4,26 & 5,89 \\
\hline
\end{tabular}


Tabela A. 3. Valores médios de peso, altura, diāmetro, espes sura da casca, suco, acidez total, sólidos solüveis e relação acidez/sólidos solúveis dos frutos, com os respectivos indices anuais $\left(I_{k}\right)$, relativos a ensaio conduzido no Recöncavo Baiano, considerando cinco porta-enxertos para copa de laranja 'Natal' e cinco anos.

\begin{tabular}{|c|c|c|c|c|c|}
\hline \multirow{2}{*}{ Porta-enxertos } & \multicolumn{5}{|c|}{ Anos } \\
\hline & 1976 & 1977 & 1978 & 1979 & 1980 \\
\hline & \multicolumn{5}{|c|}{ Peso médio dos frutos } \\
\hline $\begin{array}{l}\text { Limão Cravo } \\
\text { Laranja Caipira } \\
\text { Limão Rugoso FM } \\
\text { Tangerina Dancy } \\
\text { Limão Rugoso Fl. }\end{array}$ & $\begin{array}{l}233,60 \\
262,40 \\
245,60 \\
234,80 \\
232,20 \\
\end{array}$ & $\begin{array}{l}220,66 \\
226,66 \\
221,70 \\
209,00 \\
221,02 \\
\end{array}$ & $\begin{array}{l}2222,60 \\
233,50 \\
232,30 \\
222,40 \\
235,30 \\
\end{array}$ & $\begin{array}{l}221,20 \\
239,40 \\
224,00 \\
216,20 \\
217,30 \\
\end{array}$ & $\begin{array}{l}197,70 \\
202,70 \\
200,30 \\
206,80 \\
197,20 \\
\end{array}$ \\
\hline$I_{k}$ & 18,66 & $-3,25$ & 6,16 & 0,56 & $-22,12$ \\
\hline $\begin{array}{l}\text { Limão Cravo } \\
\text { Laranja Caipira } \\
\text { Limão Rugoso FM } \\
\text { Tangerina Dancy } \\
\text { Limão Rugoso Fl. }\end{array}$ & $\begin{array}{l}7,20 \\
7,38 \\
7,30 \\
7,20 \\
7,14 \\
\end{array}$ & $\begin{array}{r}1 \text { tura } \\
7,48 \\
7,48 \\
7,56 \\
7,38 \\
7,52 \\
\end{array}$ & $\begin{array}{r}\text { èdia dos } \\
7,62 \\
7,74 \\
7,62 \\
7,50 \\
7,70 \\
\end{array}$ & $\begin{array}{r}\text { frutos } \\
7,38 \\
7,54 \\
7,48 \\
7,38 \\
7,34 \\
\end{array}$ & $\begin{array}{l}7,10 \\
7,12 \\
7,00 \\
7,16 \\
7,00 \\
\end{array}$ \\
\hline $\mathrm{I}_{\mathrm{k}}$ & \multicolumn{5}{|c|}{ Diāmetro médio dos frutos } \\
\hline $\begin{array}{l}\text { Limão Cravo } \\
\text { Laranja Caipira } \\
\text { Limão Rugoso FM } \\
\text { Tangerina Dancy } \\
\text { Limão Rugoso F1. }\end{array}$ & $\begin{array}{l}7,56 \\
7,84 \\
7,68 \\
7,52 \\
7,54 \\
\end{array}$ & $\begin{array}{l}7,44 \\
7,48 \\
7,52 \\
7,34 \\
7,46 \\
\end{array}$ & $\begin{array}{l}7,44 \\
7,52 \\
7,52 \\
7,32 \\
7,54 \\
\end{array}$ & $\begin{array}{l}7,32 \\
7,50 \\
7,34 \\
7,22 \\
7,36 \\
\end{array}$ & $\begin{array}{l}7,00 \\
7,08 \\
7,12 \\
7,18 \\
7,04 \\
\end{array}$ \\
\hline $\mathrm{I}_{\mathrm{k}}$ & $\begin{array}{r}0,23 \\
\text { Espe }\end{array}$ & \multicolumn{3}{|c|}{ Espessura média da casca dosfrutos } & $\begin{array}{l}-0,31 \\
\text { frutos } \\
\end{array}$ \\
\hline $\begin{array}{l}\text { Limão Cravo } \\
\text { Laranja Caipira } \\
\text { Limão Rugoso FM } \\
\text { Tangerina Dancy } \\
\text { Limão Rugoso Fl. }\end{array}$ & $\begin{array}{l}4,34 \\
4,52 \\
4,60 \\
4,46 \\
4,52 \\
\end{array}$ & $\begin{array}{l}4,26 \\
4,32 \\
4,42 \\
3,88 \\
3,94 \\
\end{array}$ & $\begin{array}{l}4,00 \\
4,00 \\
4,14 \\
3,82 \\
4,20 \\
\end{array}$ & $\begin{array}{l}3,64 \\
3,70 \\
4,00 \\
3,54 \\
3,54 \\
\end{array}$ & $\begin{array}{l}3,06 \\
3,60 \\
3,26 \\
3,28 \\
3,44 \\
\end{array}$ \\
\hline$I_{k}$ & 0,55 & 0,22 & 0,09 & $-0,26$ & $-0,61$ \\
\hline
\end{tabular}


Tabela A.3. continuação

\begin{tabular}{|c|c|c|c|c|c|}
\hline \multirow{2}{*}{ Porta-enxertos } & \multicolumn{5}{|c|}{ Anos } \\
\hline & 1976 & 1977 & 1978 & 1979 & 1980 \\
\hline & \multicolumn{5}{|c|}{ Porcentagem mëdia de suco dos frutos } \\
\hline $\begin{array}{l}\text { Limão Cravo } \\
\text { Laranja Caipira } \\
\text { Limão Rugoso FM } \\
\text { Tangerina Dancy } \\
\text { Limão Rugoso Fl. }\end{array}$ & $\begin{array}{l}59,334 \\
63,166 \\
58,330 \\
61,380 \\
59,420 \\
\end{array}$ & $\begin{array}{l}58,410 \\
57,586 \\
56,984 \\
58,414 \\
55,752 \\
\end{array}$ & $\begin{array}{l}56,462 \\
55,366 \\
49,626 \\
57,604 \\
54,158 \\
\end{array}$ & $\begin{array}{l}58,356 \\
57,316 \\
57,556 \\
58,780 \\
57,406 \\
\end{array}$ & $\begin{array}{l}60,732 \\
61,664 \\
63,850 \\
62,976 \\
62,194 \\
\end{array}$ \\
\hline$I_{k}$ & $\begin{array}{l}1,81 \\
\text { Porcen }\end{array}$ & $\begin{array}{c}-1,08 \\
\text { tagem médi }\end{array}$ & $\begin{array}{l}-3,87 \\
\text { a de acide }\end{array}$ & $\begin{array}{l}-0,63 \\
2 \text { total do }\end{array}$ & $\begin{array}{r}3,77 \\
\text { os frutos } \\
\end{array}$ \\
\hline $\begin{array}{l}\text { Limão Cravo } \\
\text { Laranja Caipira } \\
\text { Limão Rugoso FM } \\
\text { Tangerina Dancy } \\
\text { Limão Rugoso Fl. }\end{array}$ & $\begin{array}{l}1,0712 \\
1,0346 \\
1,0798 \\
1,0934 \\
1,0540 \\
\end{array}$ & $\begin{array}{l}0,9042 \\
1,0184 \\
1,0714 \\
1,00008 \\
1,00512 \\
\end{array}$ & $\begin{array}{l}0,7406 \\
0,7086 \\
0,7554 \\
0,7804 \\
0,7576 \\
\end{array}$ & $\begin{array}{l}0,9836 \\
0,9308 \\
0,9776 \\
0,9470 \\
0,9528 \\
\end{array}$ & $\begin{array}{l}0,8352 \\
0,8494 \\
0,8478 \\
0,8520 \\
0,8172 \\
\end{array}$ \\
\hline$I_{k}$ & $\begin{array}{r}0,142 \\
\text { Teor }\end{array}$ & $\begin{array}{c}0,085 \\
\text { médio de }\end{array}$ & $\begin{array}{l}-0,176 \\
\text { sólidos so }\end{array}$ & $\begin{array}{c}0,034 \\
\text { 1úveis dos }\end{array}$ & $\begin{array}{r}-0,084 \\
\text { s frutos } \\
\end{array}$ \\
\hline $\begin{array}{l}\text { Limão Cravo } \\
\text { Laranja Caipira } \\
\text { Limão Rugoso FM } \\
\text { Tangerina Dancy } \\
\text { Limão Rugoso Fl. }\end{array}$ & $\begin{array}{l}11,7554 \\
11,6148 \\
11,1188 \\
12,3240 \\
11,0934 \\
\end{array}$ & $\begin{array}{l}8,7704 \\
7,6638 \\
7,4626 \\
7,5050 \\
7,7044 \\
\end{array}$ & $\begin{array}{l}8,1368 \\
7,8350 \\
6,8290 \\
7,9356 \\
8,1368 \\
\end{array}$ & $\begin{array}{l}8,5920 \\
8,9972 \\
8,3908 \\
8,8956 \\
7,8850 \\
\end{array}$ & $\begin{array}{l}9,0616 \\
9,3634 \\
8,7598 \\
9,2628 \\
8,2568 \\
\end{array}$ \\
\hline \multirow{2}{*}{$I_{k}$} & 2,65 & $-1,11$ & $-1,16$ & $-0,38$ & 0,01 \\
\hline & \multicolumn{5}{|c|}{ Relação acidez/sölidos solüveis dos frutos } \\
\hline $\begin{array}{l}\text { Limão Cravo } \\
\text { Laranja Caipira } \\
\text { Limão Rugoso FM } \\
\text { Tangerina Dancy } \\
\text { Limão Rugoso Fl. }\end{array}$ & $\begin{array}{l}11,0710 \\
11,2616 \\
10,4028 \\
11,2884 \\
10,5590 \\
\end{array}$ & $\begin{array}{l}9,7842 \\
7,5746 \\
6,9728 \\
7,5396 \\
7,3696 \\
\end{array}$ & $\begin{array}{r}11,0512 \\
11,0984 \\
9,0674 \\
10,2240 \\
10,8024 \\
\end{array}$ & $\begin{array}{l}8,7286 \\
9,7044 \\
8,5816 \\
9,4862 \\
8,3108 \\
\end{array}$ & $\begin{array}{l}10,8816 \\
11,1046 \\
10,3628 \\
10,8816 \\
10,1198 \\
\end{array}$ \\
\hline$I_{k}$ & 1,15 & $-1,92$ & 0,68 & $-0,81$ & 0,90 \\
\hline
\end{tabular}


.108.

$A P \bar{E} N D I C E$ 


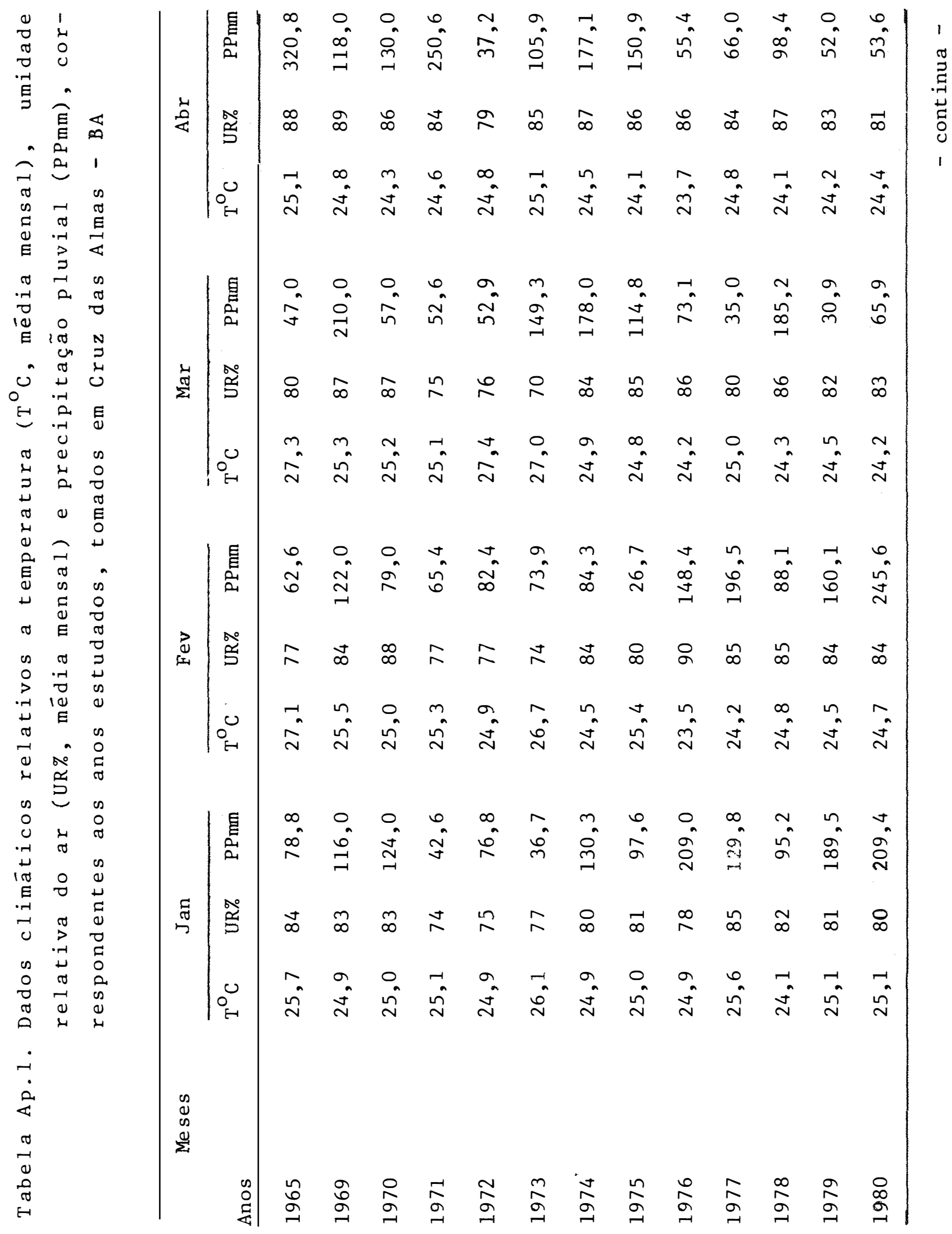




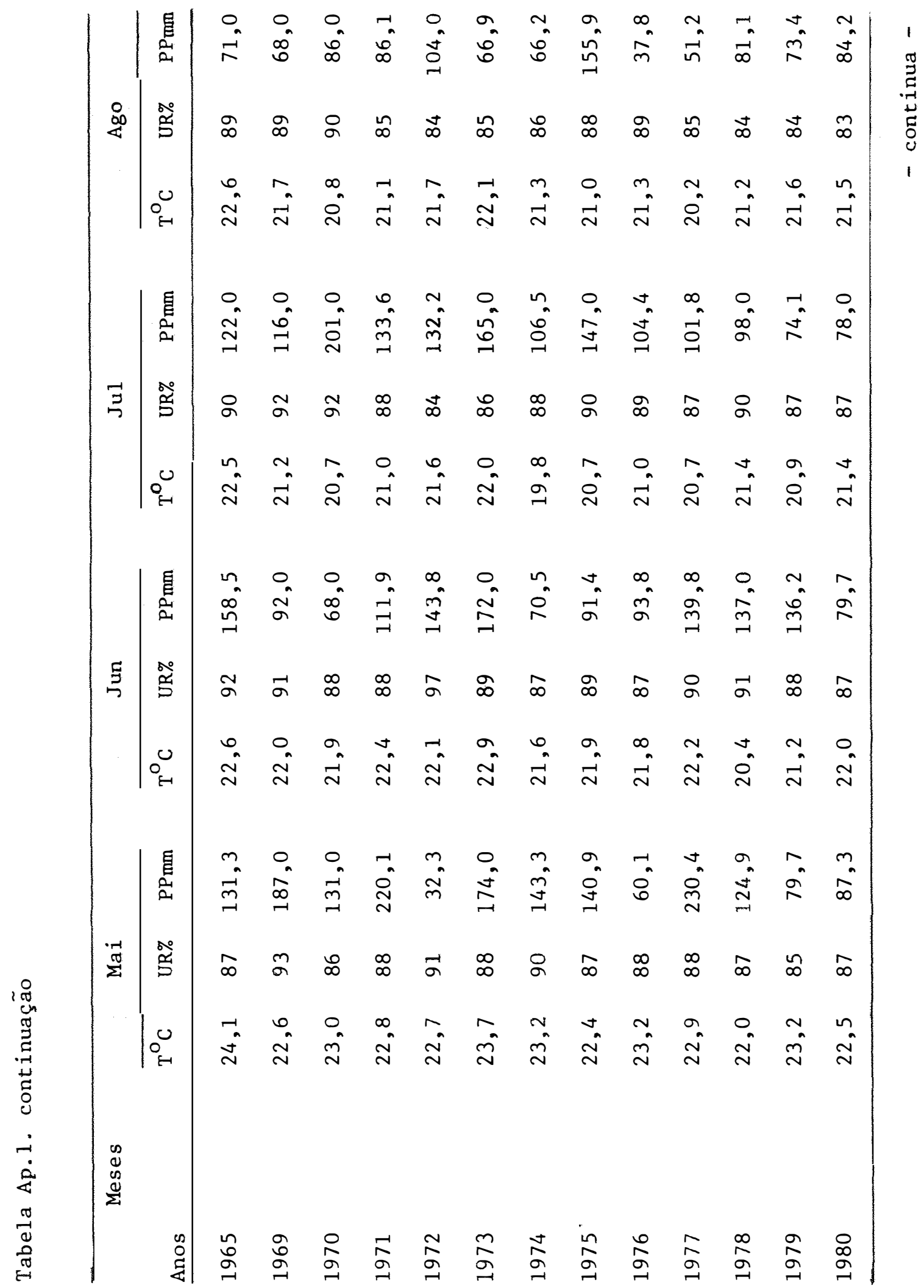




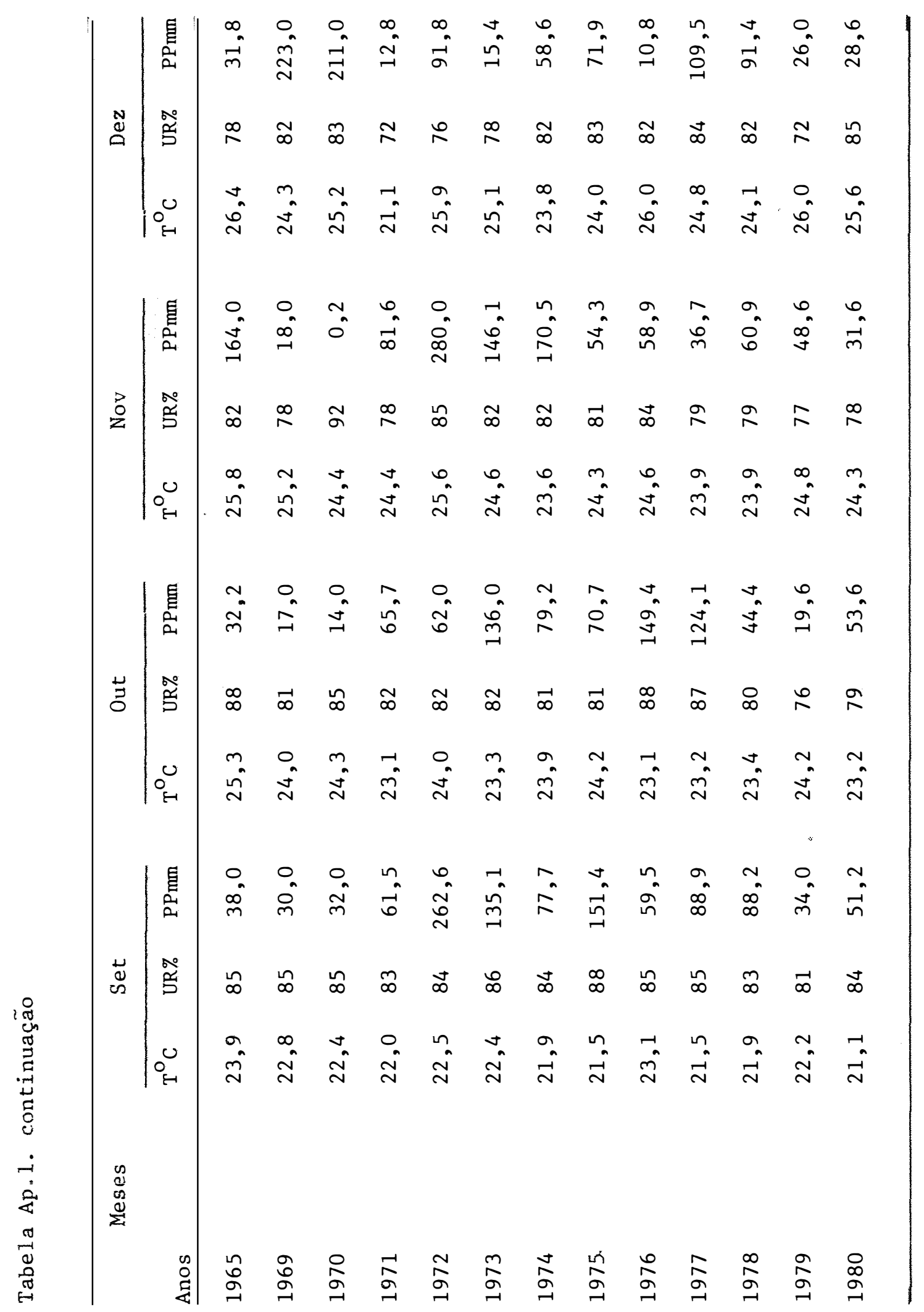

